\title{
Advances in Rosin-Based Chemicals: The Latest Recipes, Applications and Future Trends
}

\author{
Szymon Kugler ${ }^{1, *} \mathbb{D}$, Paula Ossowicz ${ }^{1} \mathbb{D}$, Kornelia Malarczyk-Matusiak ${ }^{1}$ \\ and Ewa Wierzbicka 2 (D) \\ 1 Faculty of Chemical Engineering, West Pomeranian University of Technology in Szczecin, Pulaskiego 10, \\ 70-322 Szczecin, Poland; paula.ossowicz@zut.edu.pl (P.O.); kornelia.malarczyk@zut.edu.pl (K.M.-M.) \\ 2 Industrial Chemistry Research Institute, Rydygiera 8, 01-793 Warsaw, Poland; ewa.wierzbicka@ichp.pl \\ * Correspondence: skugler@zut.edu.pl
}

Received: 22 March 2019; Accepted: 23 April 2019; Published: 26 April 2019

\begin{abstract}
A comprehensive review of the publications about rosin-based chemicals has been compiled. Rosin, or colophony, is a natural, abundant, cheap and non-toxic raw material which can be easily modified to obtain numerous useful products, which makes it an excellent subject of innovative research, attracting growing interest in recent years. The last extensive review in this research area was published in 2008, so the current article contains the most promising, repeatable achievements in synthesis of rosin-derived chemicals, published in scientific literature from 2008 to 2018. The first part of the review includes low/medium molecule weight compounds: Especially intermediates, resins, monomers, curing agents, surfactants, medications and biocides. The second part is about macromolecules: mainly elastomers, polymers for biomedical applications, coatings, adhesives, surfactants, sorbents, organosilicons and polysaccharides. In conclusion, a critical evaluation of the publications in terms of data completeness has been carried out with an indication of the most promising directions of rosin-based chemicals development.
\end{abstract}

Keywords: rosin; curing agent; resin; surfactant; biocide; medicine; polymer

\section{Introduction}

The natural origin, low price, abundance and chemical modification potential of rosin make it a valuable raw material in numerous applications [1-14]. Besides the mentioned advantages, rosin is also safe for living organisms [15]. Its derivatives are claimed as non-toxic as well, despite their allergenicity $[16,17]$. This unique set of beneficial properties of rosin determines it as an attractive subject of innovative research characterized by a considerably growing interest in recent decades, as can be seen in Figure 1.

Unfortunately, the awareness of the possibility of using rosin as a raw material for obtaining valuable chemicals is generally unsatisfactory. There is a burning need to bring this topic to the attention of a larger group of scientists. Furthermore, the growing number of publications causes difficulties in keeping up with the latest research, as well as in selection of more promising discoveries. Sadly, the last comprehensive review document dedicated exclusively to rosin and its modifications was published in 2008 [1]. Since then, only fragmentary information on rosin has appeared in review articles on bio-based polymers and resin systems [2-21], as well as in reviews on rosin derivatives in catalysis [12], controlled drug-delivery systems [13] and small-molecule compounds [14].

In view of these facts, publication of a wide, comprehensive and critical review of achievements since 2008 is an important solution to solve the problem of a severe lack of current review literature in this field. The growing number of publications is not the only obstacle in creating a literature review on rosin. No less important challenge is to collect information from existing literature. Quite often 
articles do not contain full information about a particular reaction, but refer to earlier articles, which, in turn, may refer to even earlier articles, which may not be available online, or may not be in English.

The current article is a direct answer to the aforementioned issues. Its aims are: (I) to provide a precise review of the scientific literature from 2008 to 2018, (II) select promising studies with clear practical application and (III) an overall assessment of the reviewed achievements in order to identify the most perspective development directions of rosin-based chemicals. The review is presented in a modern, pleasant-to-browse form, illustrated with patiently completed reaction schemes. The article provides concise, but exhaustive information on the achievements in preparation of rosin-derived chemicals in the last decade. Its main idea is to inspire and encourage the world of science to actively take interest in rosin and the possibilities of its modification.

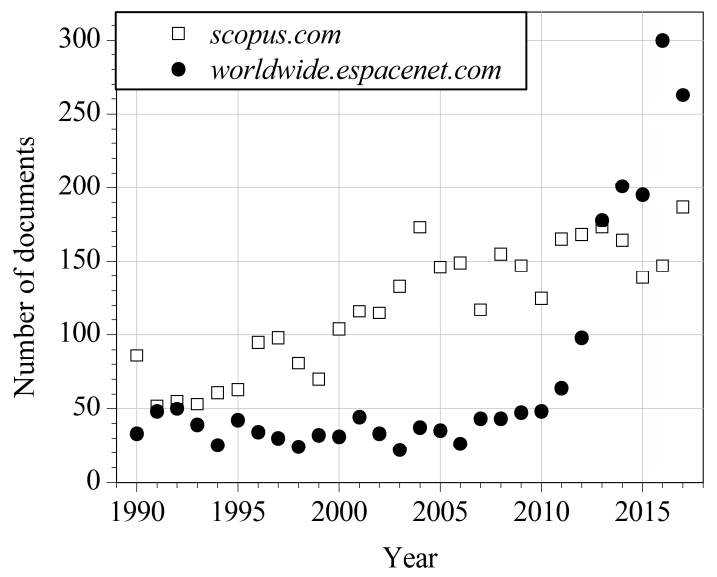

Figure 1. Number of scientific articles and patent documents containing the keyword "rosin" in the years 1990-2017.

\section{Basic Information about Rosin}

Rosin, or colophony, is a solid and brittle mixture of non-volatile conifer tree resin components. It can display colors ranging from almost colorless, through shades of yellow and brown to black. Depending on the origin, two industrially important types of rosin can be distinguished, i.e., gum rosin and tall oil rosin. Gum rosin is the non-volatile residue remaining after distillation of tree resin obtained by tapping of living trees. Tall oil rosin is a by-product of wood pulping in the kraft process. Gum rosin accounts for ca. $60 \%$ of world rosin production, whereas tall oil rosin is ca. $35 \%$. In the past, rosin was widely obtained from the solvent extraction of harvested wood as so-called wood rosin, but nowadays, this technology is of little importance [1,22]. The price of rosin in the first half of 2018 ranged from 300 to $2750 \mathrm{USD} /$ ton depending on its origin, supplier and color. Annual world production of rosin is ca. 1.2 million tons and has remained stable in the last decades [1,2,22].

Resin acids, with the general formula $\mathrm{C}_{19} \mathrm{H}_{29} \mathrm{COOH}$, constitute up to 95 wt.\% of rosin, while neutral compounds are present in amounts of a few percent. A number of resin acids based on a few diterpene carbon skeletons were identified so far [1]. The most abundant resin acids are built on abietane and pimarane skeletons. Their structural formulas are shown in Figure 2. It should be emphasized, that abietane-structured acids are characterized by conjugated double bond systems, which makes them particularly susceptible to chemical modifications. It is noteworthy, that abietane-structured acids isomerize at elevated temperature to afford readily reactive levopimaric acid, according to Scheme 1. On the other hand, pimarane-type acids do not have conjugated double bond systems, which limits their chemical processability. The detailed chemical composition of rosin depends on its type (gum, tall oil or wood), thermal history, species of tree and geographical origin [23,24]. Compositions of gum rosin from various sources are presented in Table 1, where it can be seen that the content of abietanetype acids may vary between 64 and $87 \mathrm{wt} . \%$. Such detailed composition of a rosin can be determined, e.g., by the capillary electrophoresis method [25]. 


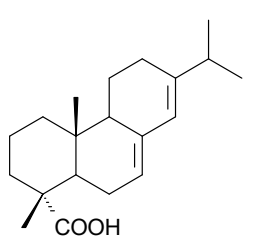

A) Abietic acid<smiles>CC(C)c1ccc2c(c1)CCC1C(C)(C(=O)O)CCCC21C</smiles>

E) Dehydroabietic acid

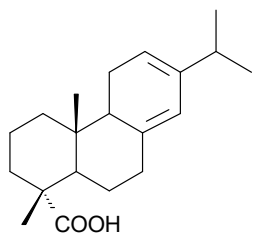

B) Levopimaric acid

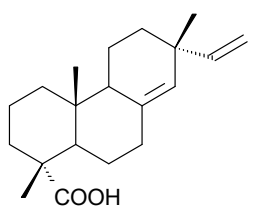

F) Sandaracopimaric acid<smiles>CC(C)C1=CC2=C(CC1)C1(C)CCCC(C)(C(=O)O)C1CC2</smiles>

C) Palustric acid

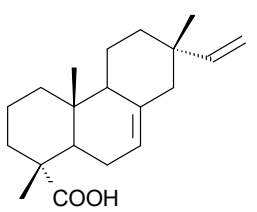

G) Isopimaric acid

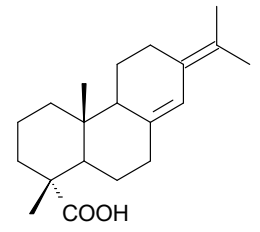

D) Neoabietic acid

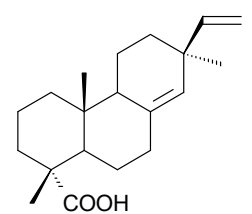

H) Pimaric acid

Figure 2. Structural formulas of the most common abietane-structured (A-E) and pimarane-structured $(\mathbf{F}-\mathbf{H})$ resin acids.

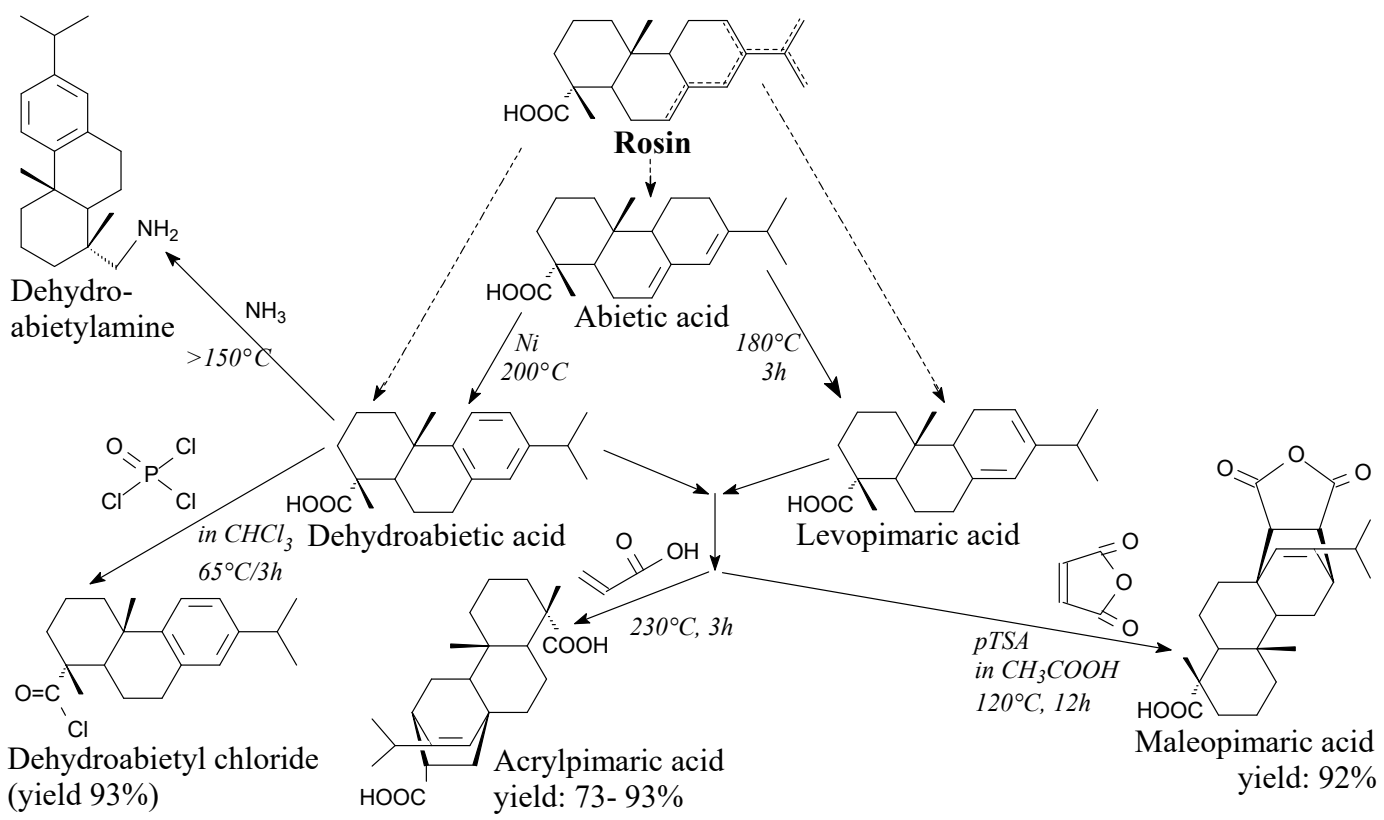

Scheme 1. Synthesis of essential rosin-based substrates/intermediates.

Table 1. Composition of resin acids in gum rosin from different sources [23].

\begin{tabular}{|c|c|c|c|c|c|c|}
\hline \multirow{2}{*}{ Species } & \multirow{2}{*}{ Origin } & \multicolumn{4}{|c|}{ Abietane-type Acids Content (wt.\%) } & \multirow{2}{*}{$\begin{array}{l}\text { Other Acids } \\
\text { (wt. } \% \text { ) }\end{array}$} \\
\hline & & Abietic & Palustric/Levopimaric & Neoabietic & Dehydroabietic & \\
\hline Pinus massoniana & China & 39 & 25 & 16 & 7 & 13 \\
\hline Pinus elliotti & Brazil & 37 & 15 & 16 & 5 & 27 \\
\hline Pinus merkusii & Indonesia & 28 & 27 & 5 & 4 & 36 \\
\hline Pinus sylvestris & Russia & 35 & 23 & 15 & 10 & 17 \\
\hline \multirow[t]{2}{*}{ Pinus halepensis } & Greece & 45 & 23 & 13 & 5 & 14 \\
\hline & France & 35 & 20 & 15 & 9 & 21 \\
\hline \multirow{3}{*}{ Pinus pinaster } & Portugal & 34 & 21 & 19 & 9 & 17 \\
\hline & Spain & 26 & 22 & 27 & 6 & 19 \\
\hline & USA & 14 & 39 & 18 & 4 & 25 \\
\hline
\end{tabular}

In recent studies unmodified rosin was used for making films, coatings and adhesives [26-42], biomedical applications [43-55], or in mining, metallurgy and construction [56-58] and for filler 
purposes [59-64]. However, chemical modification of rosin gives many-fold greater possibilities of using this raw material, which are described in the next, main section of this article.

\section{Rosin-based Chemicals}

\subsection{General Comments on the Whole Review}

The review contains short, but exhaustive descriptions of rosin-derived compound syntheses published in the scientific literature from the JCR list since 2008. It does not include older achievements in the field of rosin, that were widely described in previous review literature $[1,65]$ and commercialized [66-80]. It includes preparations of completely new chemicals, as well as new ways to synthesize already known compounds. Only products with declared or obvious practical applications have been chosen. The review is divided into two sections according to the general molecular structure of the prepared compounds, while each section is divided according to practical application and the structure similarity of the compounds. The collected data are given in the article text and in schemes. The following information are presented in the text: product name, product morphology, substrates name(s), separation techniques and practical applications. On the other hand, data such as reaction scheme, catalyst use, reaction media, temperature, pressure, time and yield are included in the schemes. There are situations where some data simply has not been reported by original authors, e.g., product morphology or yield. Such missing data could not be presented in this review. What does the above mean? The more data provided, the more advanced the research on a compound, and the more reliable the recipe. The lack of data should indicate that the research on a certain rosin derivative is probably at an early, basic stage. It has to be underlined that reaction schemes do not take into account advanced stereochemistry. Finally, almost all reactions were conducted under an inert atmosphere: nitrogen or argon, so reaction schemes do not include this information.

\subsection{Small and Medium Molecule Compounds}

This section describes rosin-derived small/medium molecule compounds with strictly defined structures that do not contain the repeated units typical for macromolecules.

\subsubsection{Intermediates}

Intermediates are the products of simple rosin modifications, which are necessary for the preparation of many new compounds. They can be synthesized in very simple, well described ways with high yields. The sustainability of these processes is high: They usually use a biobased main substrate (rosin) in solvent-free processes. Some drawback can be the separation processes, that may not always be easy, because of the high viscosity, m.p. and stickiness of products. In view of the above, rosin-based intermediates have very high commercialization potential and some of them are commercially available in certain regions of the world.

Maleopimaric acid is an off-white solid (m.p. $223^{\circ} \mathrm{C}$ ). It can be prepared from abietic acid and maleic anhydride via a Diels-Alder reaction according to Scheme 1 [81], followed by recrystallization [82]. Maleopimaric acid is one of the crucial products in rosin chemistry. It can be used directly as an epoxy resin hardener, but its applications are much wider. They include preparation of epoxy resins [83,84], acrylic resins [85-87], allyl resins [88-90], polyols [91], bio-based curing agents for synthetic epoxy resins [92-98] or bio-based ones [99], surfactants [100-103], intermediates [104,105], biologically active compounds [105-108], polyurethanes [109-112], chemicals for NMR techniques [113] and photolitography [114], sorbents [115], organosilicon compounds [116], printing inks [117] and for the hydrophobization of wood surfaces [118-120]. It is noteworthy that the main degradation products of maleopimaric acid are water, carbon dioxide, formamide and also aliphatic and aromatic derivatives [121]. It is worth noting that fumaropimaric acid is an isomer of hydrated maleopimaric acid, which can be synthesized in a similar way [122], but its importance to rosin chemistry is much smaller: it can be used in synthesis of triglycidyl epoxy resin [122] and water-borne polyurethanes [109]. 
Acrylpimaric acid is an off-white solid (m.p. $220^{\circ} \mathrm{C}$ ). It can be prepared from abietic acid and acrylic acid according to Scheme 1 , followed by precipitation, filtration, washing and recrystallization [123,124]. It is noteworthy that neat rosin can be acrylated as well [125]. As an important material in rosin chemistry, acrylpimaric acid can be used for preparation of diallyl acrylpimarate [123], polyesters of acrylated rosin and polyethylene glycols [125], epoxy resins [126,127], acrylpimaryl dichloride [128,129], acrylpimaric acid amides [130], cyclic diamide [131], quaternary ammonium salts [132-136], calcium and zinc salts [137] as well as polyesters [138]. Moreover, it can be used directly as an epoxy curing agent [139].

Another important compound in this subsection is dehydroabietyl chloride. It is a viscous, yellow, oily liquid $[140,141]$. It can be prepared using: (i) oxalyl chloride according to Scheme 1 prior to evaporation of unnecessary substances [142], (ii) phosphorus trichloride in chloroform (yield 92.5\%) [140] or (iii) thionyl chloride in presence of 4-dimethylaminopyridine [143]. It can be used as a substrate for the synthesis of macroinitiators for atom transfer radical polymerization (ATRP) reactions [142], rosin phosphate esters [140], $N$-hydroxyethylacrylamide ester of dehydroabietic acid [144], dehydroabietic ethyl methacrylate [145,146], dehydroabietic propargyl ester [147] dehydroabietic hexyl acrylate [148], as well as other intermediates in synthesis of various surfactants [143,149] and medicines [141,150,151].

Dehydroabietylamine, also known as leelamine, is a solid (m.p. $44.5^{\circ} \mathrm{C}$ ). It is commercially available. Its application in antitumor therapies was investigated in recent years [152-155]. Moreover, it can be a substrate for preparation of epoxy resin [156], bio-based benzoxazines [157], quaternary ammonium surfactants [158,159], acrylic monomers: glycidyl methacrylate monomer [160] or $N$-dehydroabietic acrylamide [161].

\subsubsection{Resins and Monomers}

Rosin-based resins and monomers are compounds which contain epoxy, acrylic, allyl, hydroxyl or oxazine reactive groups, that enable cross-linking, polymerization or building in the polymer matrix. Their preparations are usually well described and easy to perform. The syntheses are similar to conventional resins/monomers preparations, however the necessity of using organic solvents in several reactions is a disadvantage in the context of Green Chemistry rules. The high modification potential of rosin derivatives allows one to prepare resins and monomers showing diverse and designable properties. They can exhibit adjustable glass transition temperatures, low volume shrinkage, as well as improve elastic modulus, Young's modulus, shape-memory, flame retardancy, corrosion protection features of final casts/polymers in comparison with petroleum-based compounds. Therefore, the best described recipes show high commercialization potential in the segment of resins, adhesives and paints, but in most cases, additional applied research should be performed to increase their technology readiness level (TRL).

Triglycidyl ester of maleopimaric acid is a beige, viscous liquid. It can be prepared from maleopimaric acid, epichlorohydrin and sodium hydroxide according to Scheme 2, followed by filtration, washing and evaporation [83]. It can be used in liquid epoxy resins [83], non-cytotoxic bio-based epoxypolyurethanes [162] as well as synthesis of rosin-based cyclic carbonates [132]. Similar liquid resin can be synthesized from fumaropimaric acid [122].
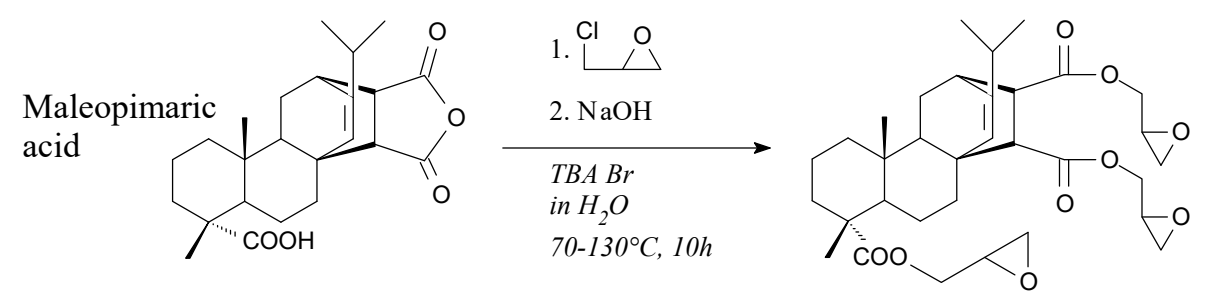

Maleopimaric acid triglycidyl ester yield: $75 \%$

Scheme 2. Synthesis of triglycidyl ester of maleopimaric acid. 
Diglycidyl acrylpimarate is a yellowish liquid. It can be prepared from acrylpimaric acid, epichlorohydrin and sodium hydroxide according to Scheme 3, prior to filtration, washing and drying [126]. It can be used in epoxy materials showing improved thermal, mechanical and shape-memory properties [126].

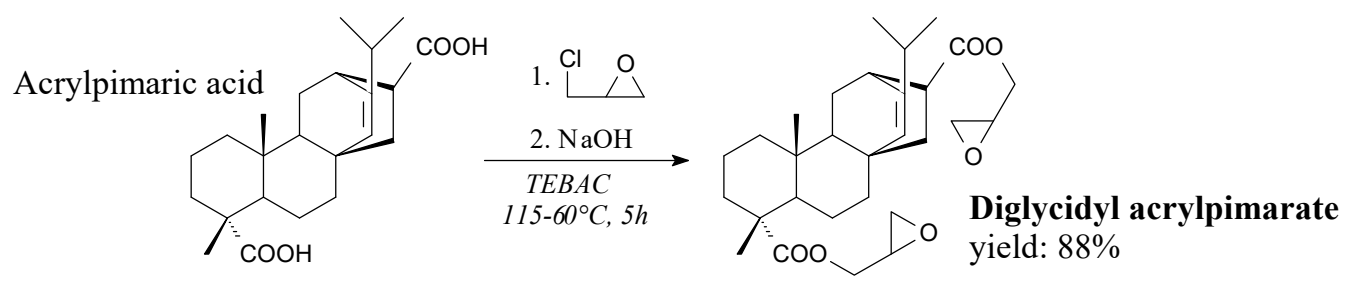

Scheme 3. Synthesis of diglycidyl acrylpimarate.

Another diglycidyl derivative of acrylpimaric acid and its siloxane modification can be prepared according to Scheme 4, prior to washing, filtration and vacuum evaporation [127]. Prepared epoxy resins can improve the thermal stability and flame retardancy of products [127].

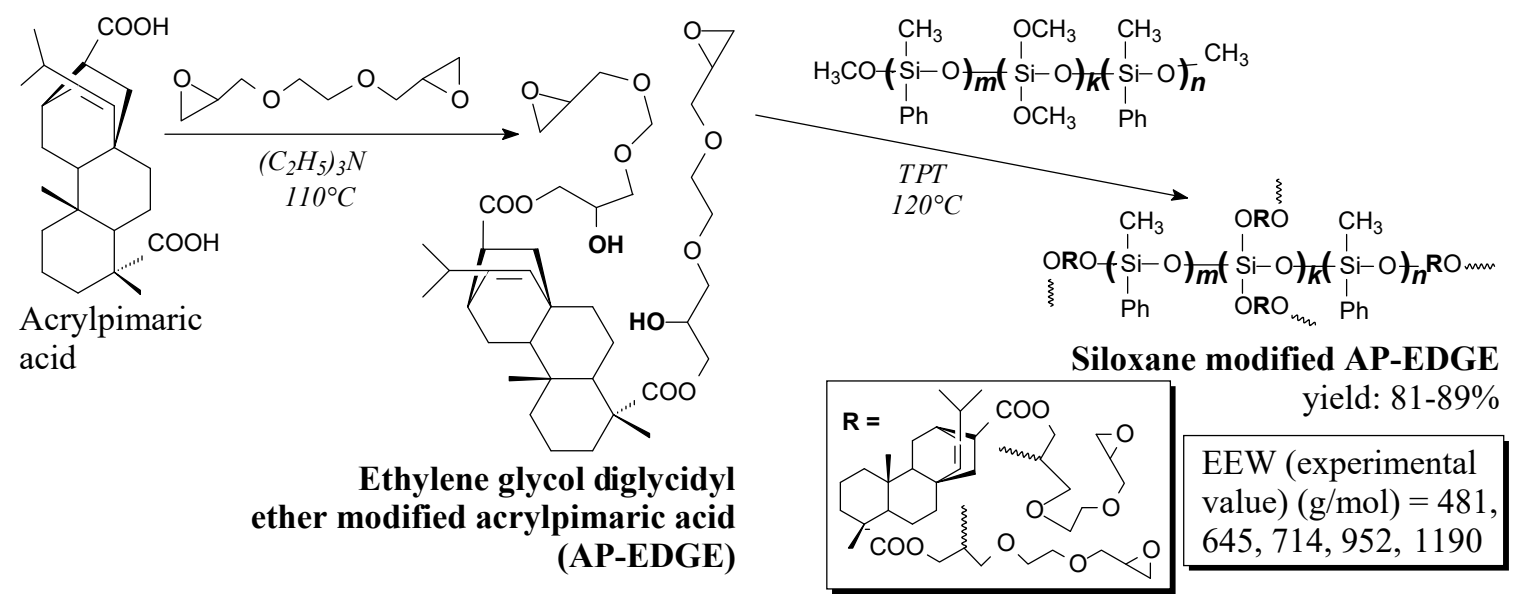

Scheme 4. Preparation of ethylene glycol diglycidyl ether modified acrylpimaric acid and its siloxane derivative.

Dimaleopimaryl ketone is a brownish yellow solid. It can be prepared from levopimaric acid and maleic anhydride according to Scheme 5, prior to washing and recrystallization [163]. It can be used directly as an epoxy resin hardener, as well as for the synthesis of bio-based epoxy resins, i.e., tetraglycidyl dimaleopimaryl ketone, according to Scheme 5 [163].

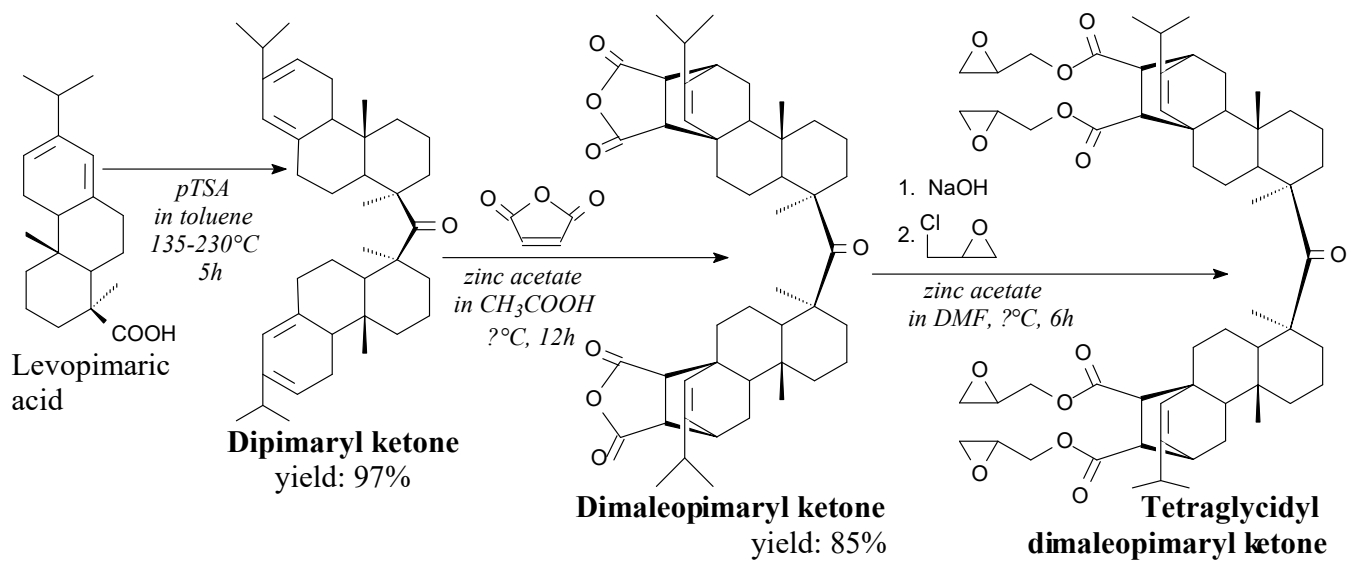

Scheme 5. Synthesis of tetraglycidyl dimaleopimaryl ketone. 
Rosin pentaglycidyl ether is a solid. It can be prepared from epoxidized rosin, water, potassium hydroxide and epichlorohydrin according to Scheme 6, and using such separation methods as vacuum drying, filtration, precipitation and washing [164]. It can be used as a component in epoxy resin systems showing high glass transition temperature as well as elastic modulus [164].

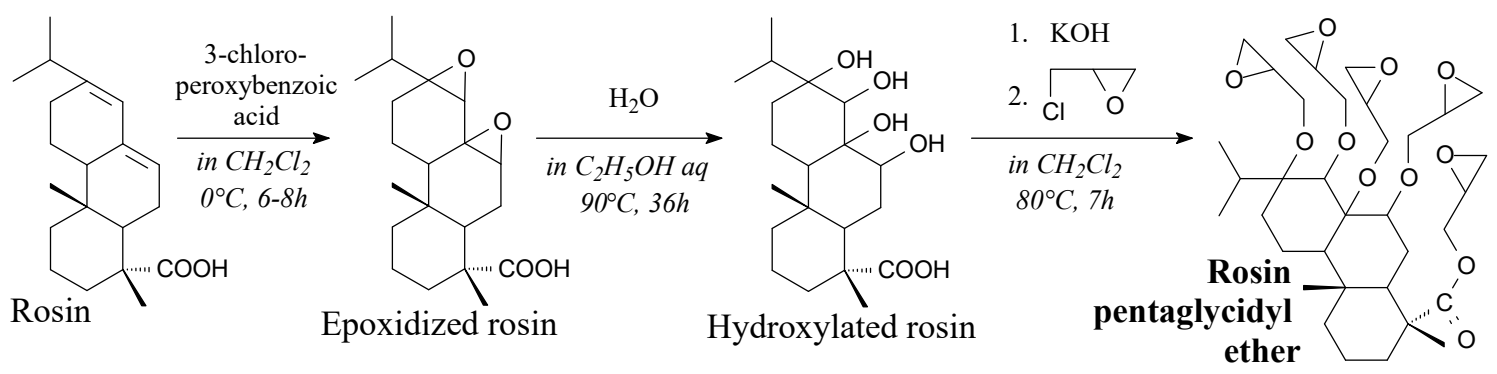

Scheme 6. Synthesis of rosin pentaglycidyl ether.

Polygral is a solid byproduct of the paper and forestry industry, containing rosin acids and their oligomers [165]. It can be epoxidized to prepare bio-based epoxy resins. Endocyclic epoxidized polygral is a red brown solid, which can be prepared using 3-chloroperoxybenzoic acid, according to Scheme 7, prior to vacuum evaporation. On the other hand, exocyclic epoxidized polygral is a viscous red brown liquid, that can be prepared in two ways, using oxalyl chloride or $N, N^{\prime}$-diisopropyl carbodiimide before addition of glycidol, according to Scheme 7 prior to washing and vacuum drying. They can be used for preparing bisphenol A-free epoxy resins [165].

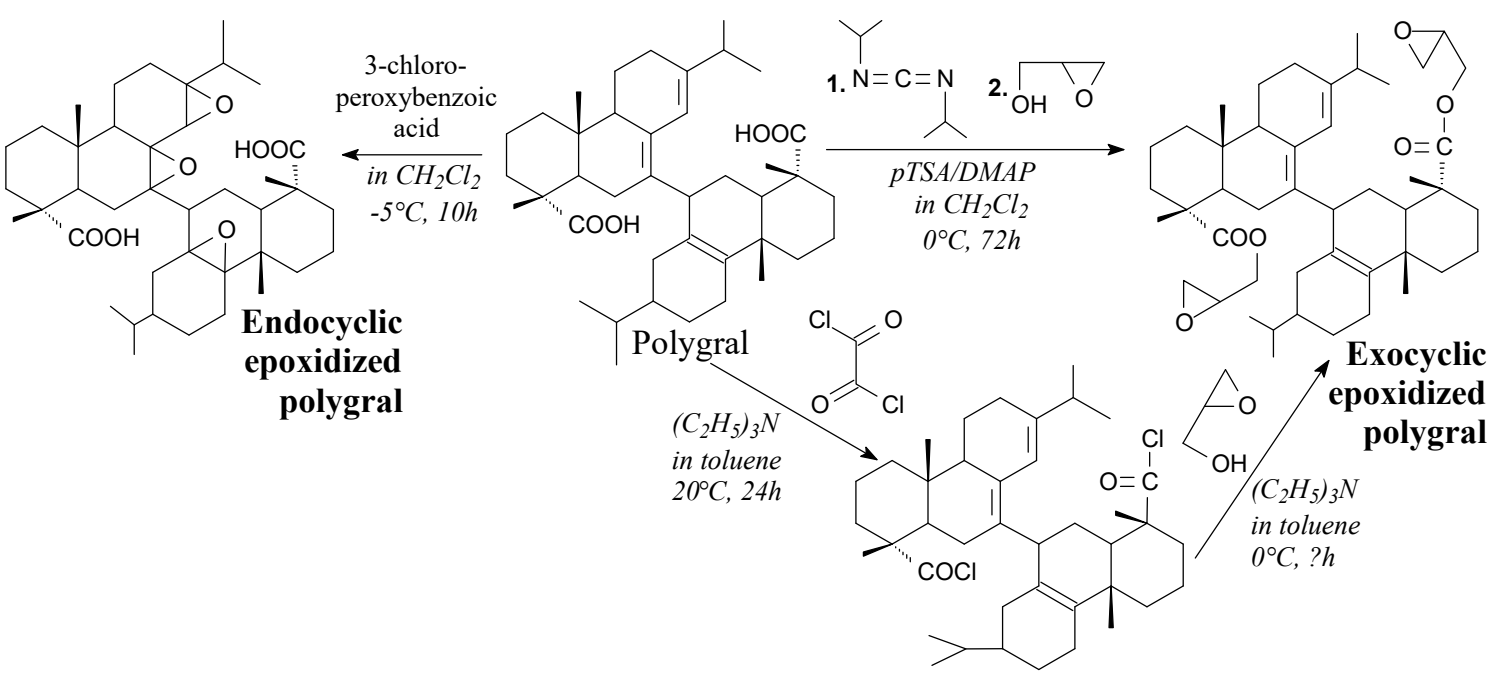

Scheme 7. Preparation of epoxidized rosin oligomers.

Diglycidyl dehydroabietylamine is a yellowish sticky liquid. It can be synthesized from dehydroabietylamine, epichlorohydrin and sodium hydroxide according to Scheme 8, prior to filtration, washing, drying and vacuum distillation [156]. It can be applied in epoxy resins exhibiting better thermal stability and higher glass transition temperatures than petroleum-based products [156].

Rosin maleimidodicarboxylic acid diglycidyl ether is a yellowish solid. It can be prepared from epichlorohydrin and dicarboxylic derivative of maleimide (described in more detail in Section 3.2.3) according to Scheme 9 prior to filtration, washing, drying and rotary evaporation [84]. It shows higher glass transition temperature, modulus and thermal stability than its plant oil counterparts [84]. 


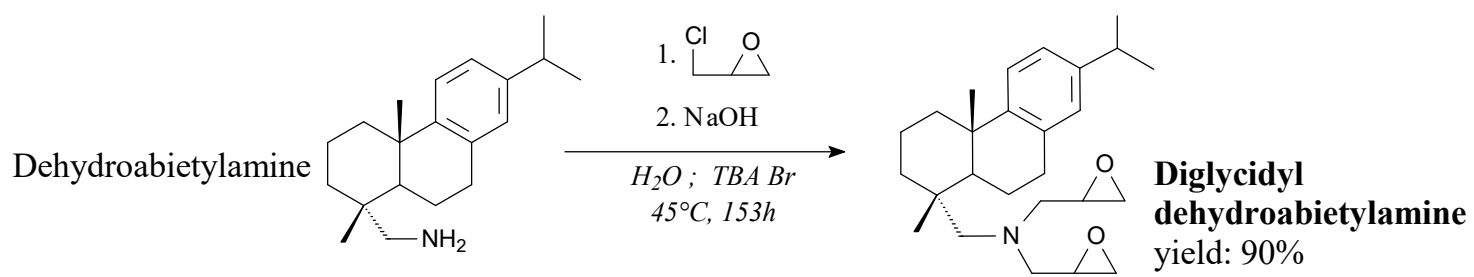

Scheme 8. Synthesis of diglycidyl dehydroabietylamine.

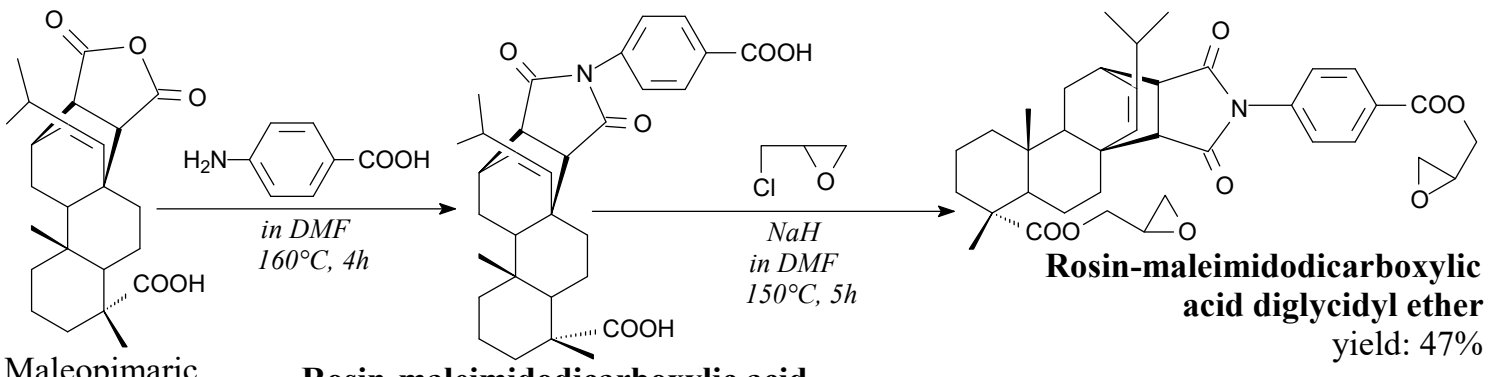

Maleopimaric acid

Rosin-maleimidodicarboxylic acid yield: $87 \%$

Scheme 9. Preparation of rosin maleimidodicarboxylic acid diglycidyl ether.

Triester of maleopimaric acid and trimethylolpropane is a dark yellow solid. It can be prepared according to Scheme 10, prior to washing and vacuum distillation [98]. It can be used in synthesis of rosin-based epoxy resin [98].<smiles>CC(C)C12C=CC3(CCC4C5(C)CCC[C@](C)(C(=O)O)C5CCC43C)C1C(=O)OC2=O</smiles>

Maleopimaric acid

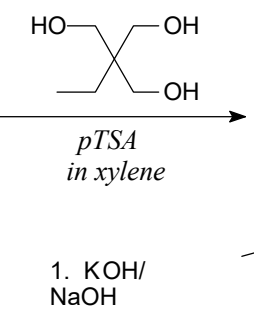

2.

Cl $\mathrm{O}$
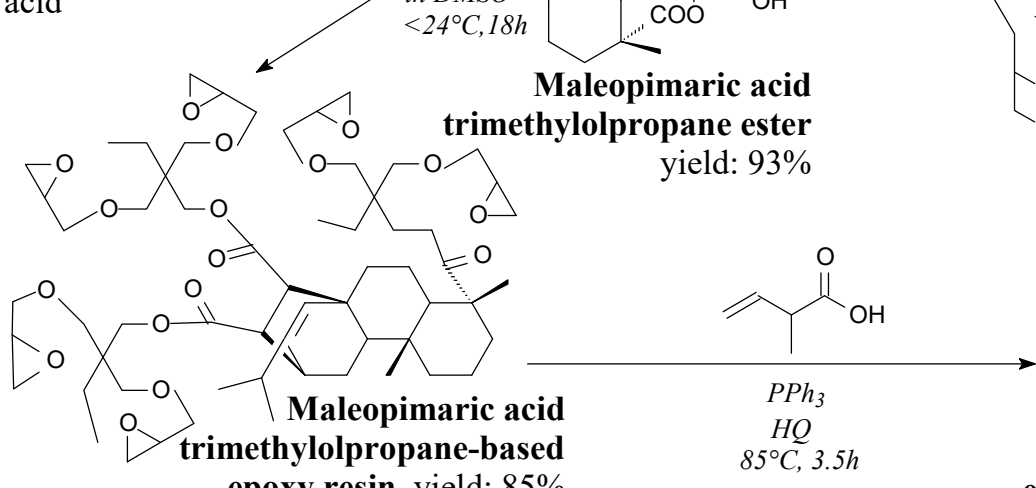

epoxy resin yield: $85 \%$

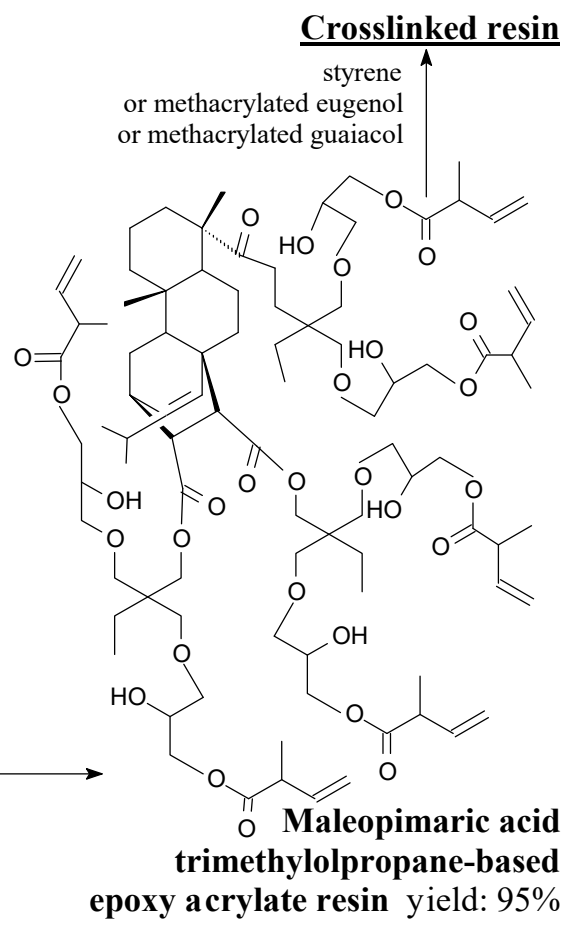

Scheme 10. Preparation of maleopimaric acid-trimethylolpropane ester-based epoxy acrylate resin crosslinked by unsaturated monomers.

Epoxy resin having EEW $=199.68 \mathrm{~g} / \mathrm{eq}$ based on maleopimaric acid and trimethylolpropane ester can be prepared according to Scheme 10, prior to extraction and vacuum distillation [98]. It can be used directly as an epoxy compound, or transformed into acrylate resin [98]. 
Acrylate resin based on epoxidized maleopimaric-trimethylolpropane adduct can be prepared according to Scheme 10 [98]. It can be used as a resin crosslinked by styrene, methacrylated eugenol or methacrylated guaiacol [98].

Dehydroabietic ethyl methacrylate is a white powder. It can be prepared from dehydroabietyl chloride and hydroxyethyl methacrylate according to Scheme 11, prior to neutralization, drying, evaporation and chromatography [146]. It can be widely used as a monomer in preparation of graft and block copolymers [146,166-170]. It is worth noting, that a similar compound dehydroabietic ethyl acrylate is a yellow, viscous liquid, which can be prepared from hydroxyethyl acrylate and dehydroabietyl chloride prior to filtration, precipitation and vacuum distillation [171]. It can be used for preparation of homopolymer with no declared application [171]. Moreover, rosin ethyl acrylate can be used in preparation of bio-based graft copolymers of chitosan for controlled release applications [172].<smiles>CCOC(=O)CCC1CCc2cc(C(C)C)ccc2C1(C)C(=O)OC</smiles>

Dehydroabietic ethyl acrylate

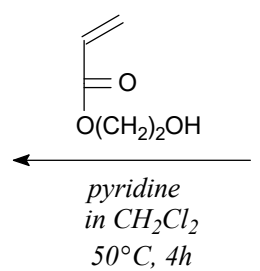

Scheme 11. Synthesis of dehydroabietic ethyl acrylates.

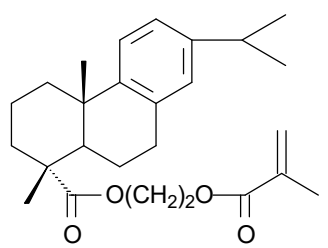

Dehydroabietic ethyl methacrylate

Dehydroabietic hexyl acrylate is a solid. It can be synthesized from dehydroabietyl chloride, hexanediol and acryloyl chloride according to Scheme 12, and using separation methods such as filtration, precipitation, washing and vacuum drying [148]. Its application is a soft acrylic monomer (glass transition temperature of $-23^{\circ} \mathrm{C}$ ), which can impart a flexibility to the integrated polymer [148].

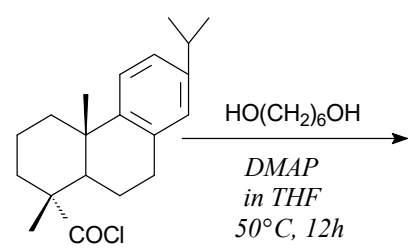

Dehydroabietyl chloride

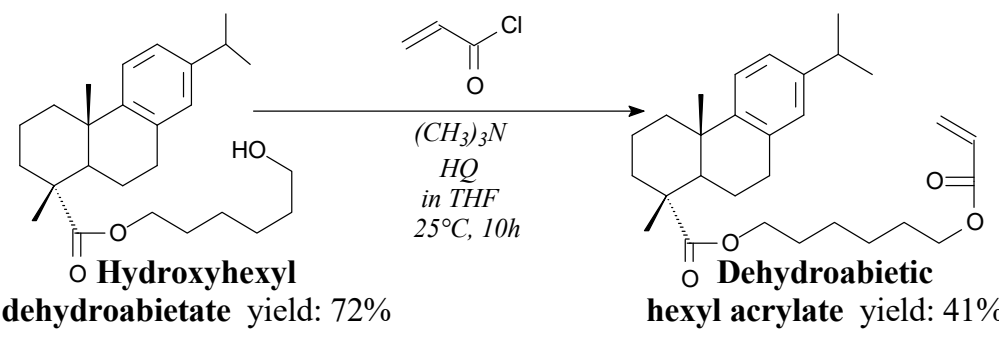

Scheme 12. Synthesis of dehydroabietic hexyl acrylate.

$N$-hydroxyethylacrylamide ester of dehydroabietic acid is a viscous, yellow liquid. It can be prepared from dehydroabietyl chloride and N-hydroxyethylacrylamide according to Scheme 13, prior to filtration, washing, drying and column chromatography [144]. It can be used as a monomer in thermoset system with soybean oil-based resin for coating and adhesive applications [144].

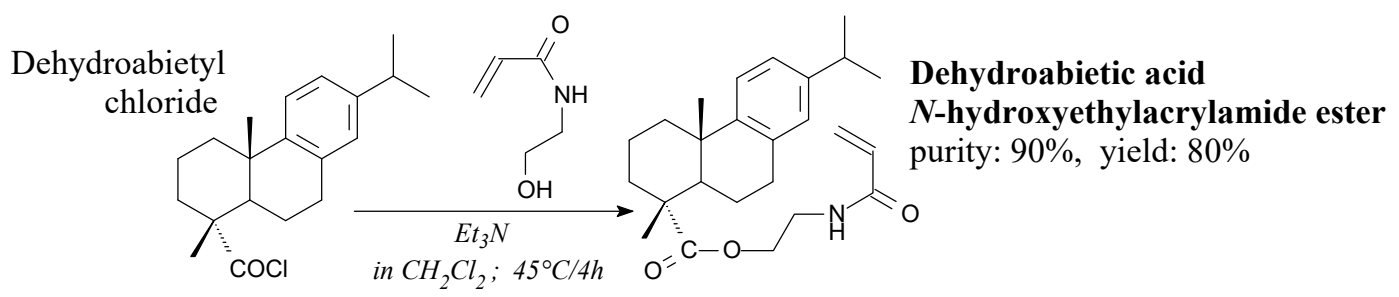

Scheme 13. Synthesis of $N$-hydroxyethylacrylamide ester of dehydroabietic acid.

Rosin-based high adhesion polyurethane acrylate is a faint-yellow solid. It can be synthesized from hydrogenated rosin, isophorone diisocyanate and 2-hydroxyethyl acrylate according to Scheme 14, 
prior to precipitation, vacuum drying and column chromatography [173]. Its application is an adhesive having a high polymerization rate, low volume shrinkage and high adhesion [173].

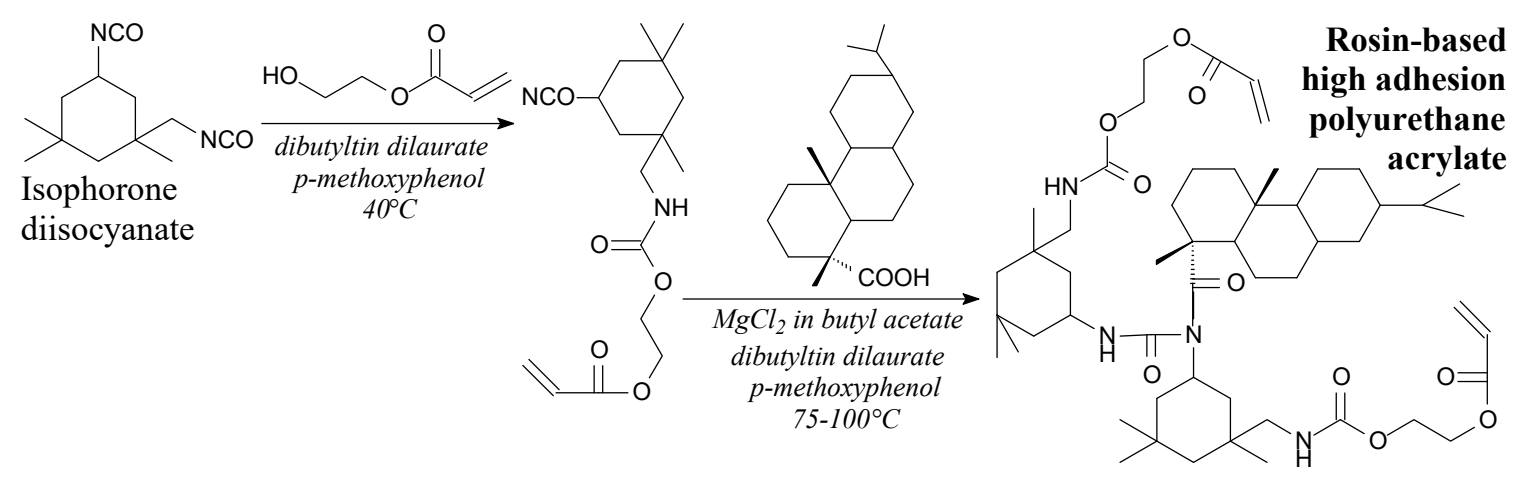

Scheme 14. Synthesis of rosin-based high adhesion polyurethane acrylate.

Rosin-based glycidyl methacrylate monomers are viscous liquids: brown rosin acid-glycidyl methacrylate and colorless dehydroabietylamine-glycidyl methacrylate. They can be prepared from glycidyl methacrylate and rosin or dehydroabietylamine according to Scheme 15, prior to the use of such separation techniques as washing, extraction and evaporation $[160,174]$. They significantly improve thermal and mechanical properties of soybean oil-based thermosets [160]. Moreover, they can be used in copolymerization with other acrylate monomers [175], or as an advanced tackifier in the UV-crosslinking pressure sensitive adhesives $[174,176]$.<smiles>CC(C)C1=CC2=CCC3C(C)(C(=O)O)CCCC3(C)C2CC1</smiles>

Rosin acid

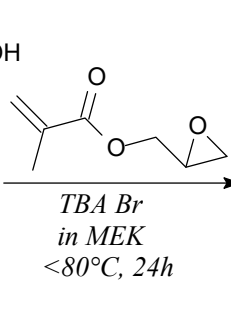

Rosin acid-glycidyl methacrylate monomer yield: $95 \%$

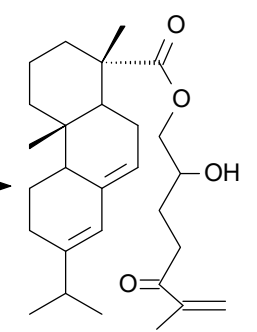

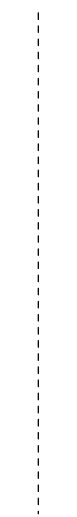

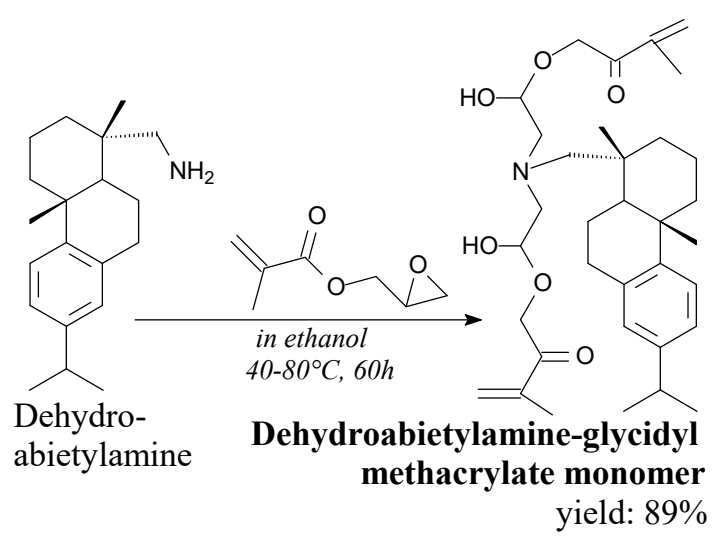

Scheme 15. Synthesis of rosin-based glycidyl methacrylate monomers.

Ethylene glycol maleic rosinate (meth)acrylate can be prepared from maleated rosin, ethylene glycol and (meth)acrylic acid according to Scheme 16 [85]. It can be applied in styrene-acrylate copolymers increasing their thermal stability [86], as well as in preparation of moleculary imprinted polymers for stationary phases used in high-performance liquid chromatography [85,87].

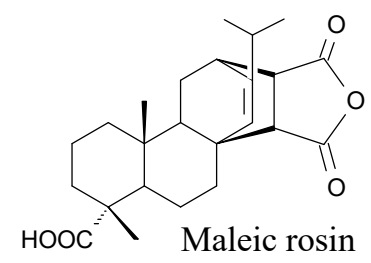<smiles>[R]C(=C)C(=O)OCCO</smiles>

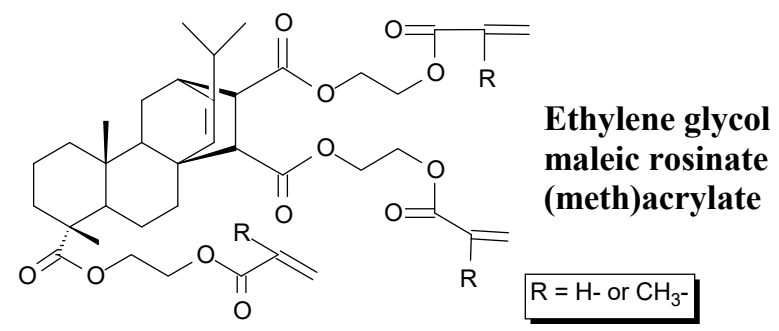

Scheme 16. Preparation of ethylene glycol maleic rosinate acrylate. 
Diallyl acrylpimarate is a yellow liquid [123]. It can be prepared from acrylpimaric acid and an allyl halide by different methods, according to Scheme 17, and using separation methods such as filtration, washing, extraction and evaporation $[88,123,177]$. It can be applied as a monomer in polyester unsaturated resins from renewable resources [123], or in synthesis of aminated curing agent for epoxy [178].

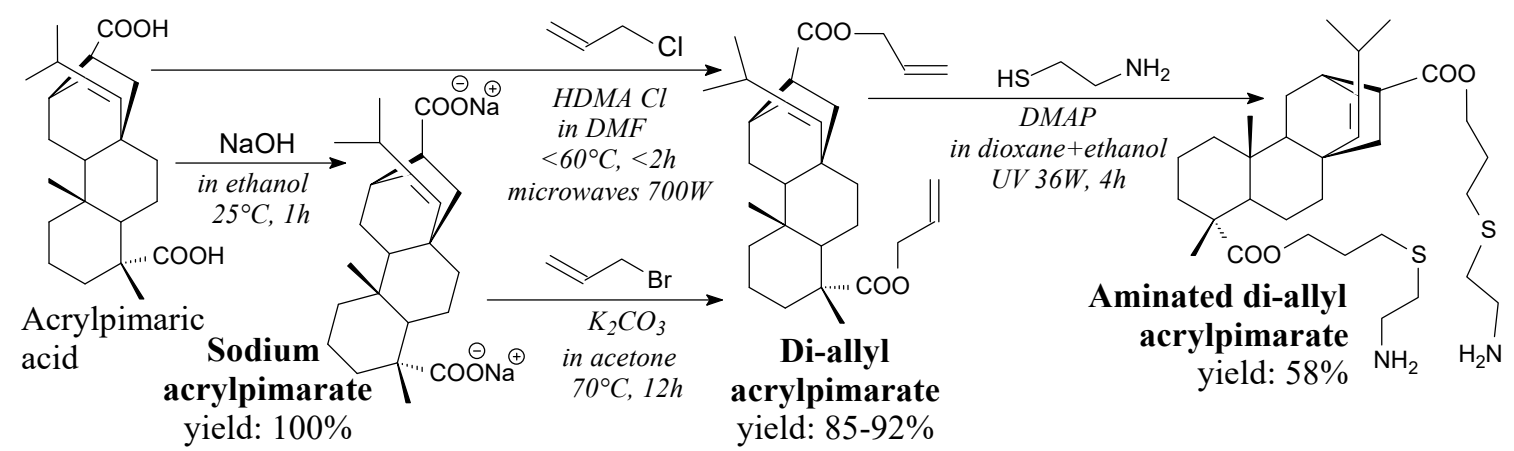

Scheme 17. Synthesis of diallyl acrylpimarate and its aminated derivative.

Aminated diallyl acrylpimarate is a yellow-brown solid. It can be synthesized from diallyl acrylpimarate and cysteamine hydrochloride according to Scheme 17, prior to washing, extraction and evaporation [178]. It can be applied as a resin or a curing agent for epoxy resins, giving them improved thermal and shape-memory properties [178].

Sodium maleopimarate is a solid, which can be prepared from maleopimaric acid according to Scheme 18 prior to drying at $40{ }^{\circ} \mathrm{C}$ [89]. Its applications include the synthesis of triallyl maleopimarate.

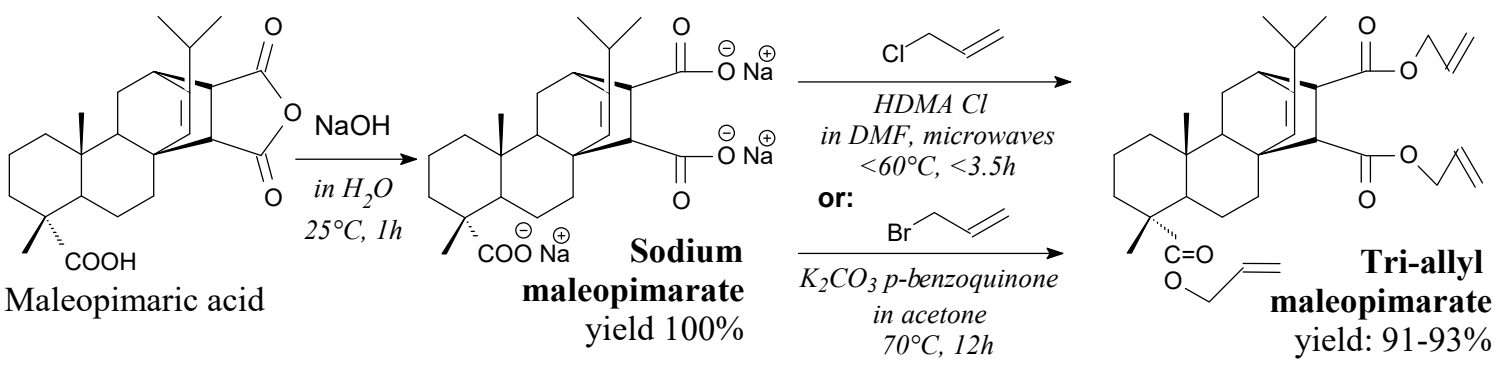

Scheme 18. Synthesis of triallyl maleopimarate.

In a similar way dehydroabietic acid salts can be synthesized for use as nucleating agents for isotactic polypropylene in a non-isothermal crystallization process, improving the crystallization temperature and accelerating the nucleation rate $[179,180]$. Triallyl maleopimarate is a white viscous liquid, which can be prepared from sodium maleopimarate and allyl halide according to Scheme 18, prior to extraction, washing, filtration and vacuum distillation [88,89]. It can be used as a monomer in UV-cured polymer films and coatings, giving them improved adhesion and mechanical properties [89], as well as in thermally cured fully bio-based resin systems exhibiting satisfactory thermal and mechanical properties [88].

Mono-allyl rosin derivatives have been also synthesized in recent years. Allyl rosinate can be prepared in aqueous [181] or ethanol [182] medium from rosin, sodium hydroxide and allyl chloride according to Scheme 19, prior to filtration and distillation [181]. It can be potentially applied as an unsaturated monomer in copolymerization reactions [181] as well as in UV-cured resins [182]. On the other hand, allyl maleopimarate can be prepared in THF from maleopimaric acid, oxalyl chloride and allyl alcohol according to Scheme 19, and using such separation methods as vacuum distillation and column chromatography [90]. It can be used in unsaturated resins and epoxy resins as a cross-linking agent [90]. 

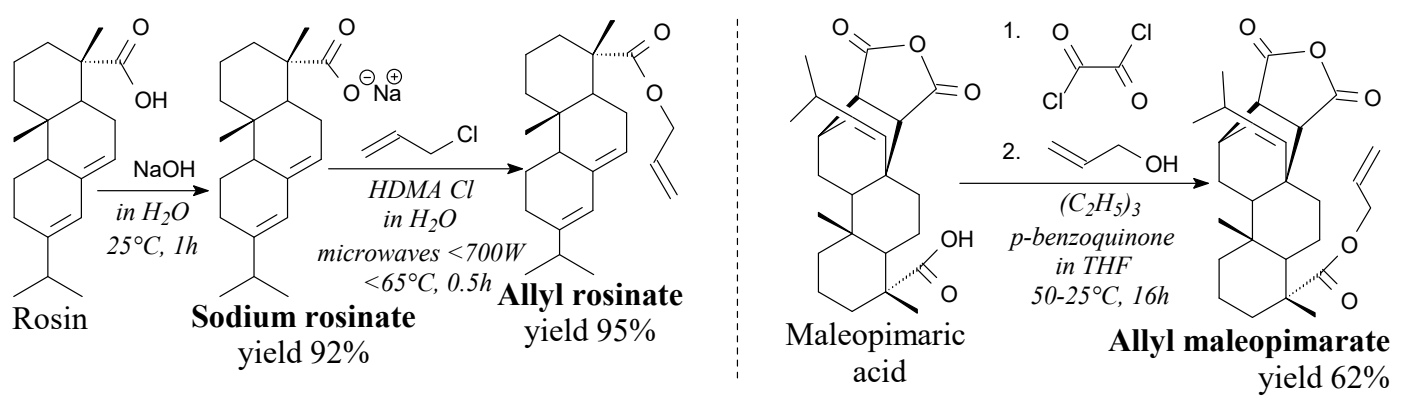

Scheme 19. Synthesis of mono-allyl rosin derivatives.

Benzoxazines are compounds consisting of a bicyclic group with an oxazine moiety. Maleopimaric acid imidophenol is a white, crystal solid. It can be synthesized from maleopimaric acid and 4-aminobenzoic phenol according to Scheme 20, prior to precipitation and drying [96]. It can be used in synthesis of benzoxazine monomers [96].

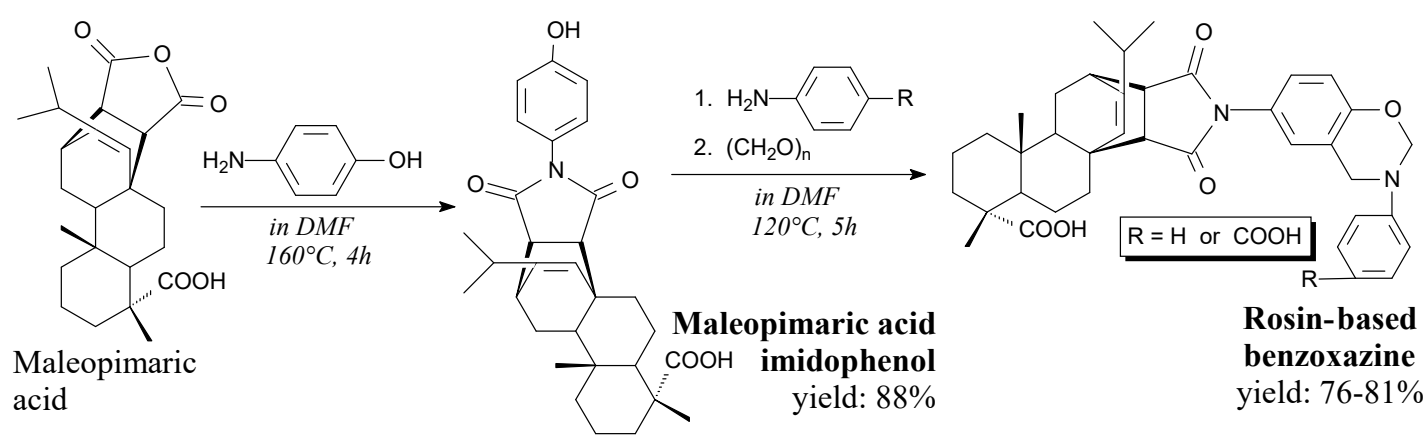

Scheme 20. Synthesis of maleopimaric acid imidophenol and its benzoxazines.

Rosin-based benzoxazine monomers are orange solids. They can be synthesized from maleopimaric acid, paraformaldehyde and aniline or 4-aminobenzoic acid, according to Scheme 20, prior to filtration, washing and rotary evaporation [96]. They can be polymerized into products of significant thermal stability [96].

Dehydroabietylamine-guaiacol (brown powder, m.p. $104{ }^{\circ} \mathrm{C}$ ) and dehydroabietylamine-4methylumbelliferone (yellow spherical crystal solid, m.p. $131^{\circ} \mathrm{C}$ ) are fully bio-based benzoxazines [157]. They can be synthesized from dehydroabietylamine via Mannich condensation, according to Scheme 21 . They can compound resins with strong corrosion protection and thermal stability [157].

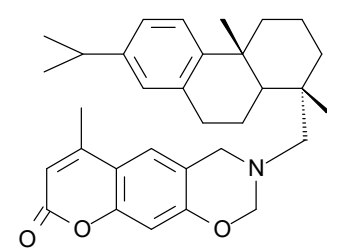

Dehydroabietylamine -4-methylumbelliferone benzoxazine yield: $70 \%$

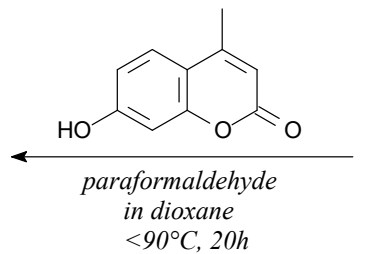

Dehydroabietylamine

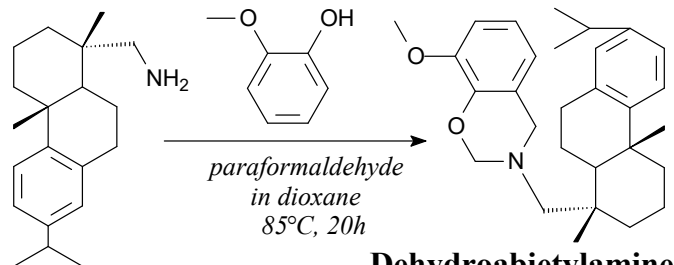

Dehydroabietylamine -guaiacol benzoxazine yield: $64 \%$

Scheme 21. Synthesis of fully bio-based benzoxazines.

\subsubsection{Hardeners}

Rosin-based hardeners, i.e., curing agents, are compounds containing anhydride, carboxyl or hydroxyl groups, which allows one to apply them in epoxy or urethane resin systems. In comparison with petroleum-based hardeners they bring improved endurance and thermal properties to resin 
systems. Moreover, rosin-based anhydrides are non-toxic, as opposed to conventional anhydride curing agents. Their preparation is simple and well described, and usually does not require the use of solvents. These strengths cause the great interest in use of rosin based chemicals as hardeners of conventional and bio-based resins resulting in several commercializations of e.g., maleated rosins.

Methyl maleopimarate is a white solid. It can be prepared from abietic acid, iodomethane and maleic anhydride, according to Scheme 22, prior to recrystallization [82]. It can be used as bio-based curing agent for epoxies [82,183], as well as in synthesis of binaphthyl-appended crown ethers derived from rosin [184].

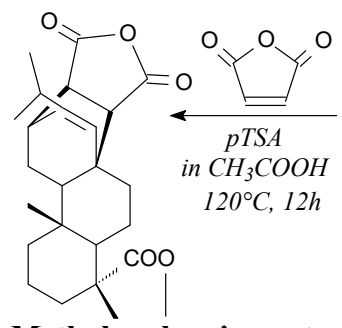

Methyl maleopimarate yield $90 \%$

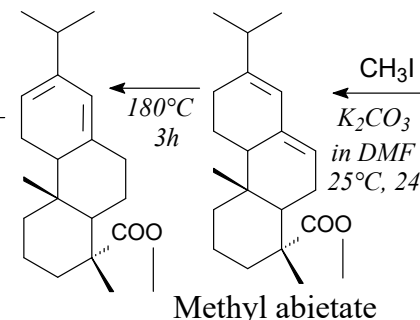

Methyl abietate yield: $81 \%$

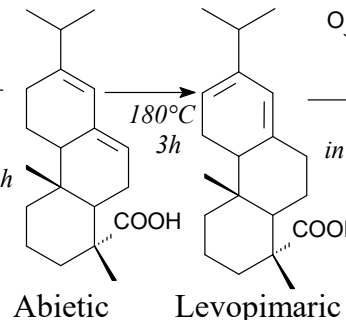

acid

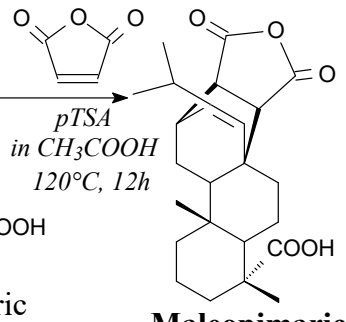

Maleopimaric acid yield: $92 \%$

Scheme 22. Synthesis of maleopimaric acid and methyl maleopimarate.

Rosin-maleimidopolycarboxylic acids are white/yellowy or gray/brown powders. They can be prepared from maleopimaric acid with aspartic or 4-aminobenzoic acid, or rosin with 1,1'-(methylenedi4,1-phenylene)bismaleimide, according to Scheme 23, before separation via such methods as precipitation, filtration, washing, drying and recrystallization [94,185]. They have a potential to replace petroleum-based epoxy curing agents [94,185]. Furthermore, rosin-maleimidodicarboxylic acid can be used for synthesis of rosin-based chain extender for polyurethanes [186], or epoxy resins [84].
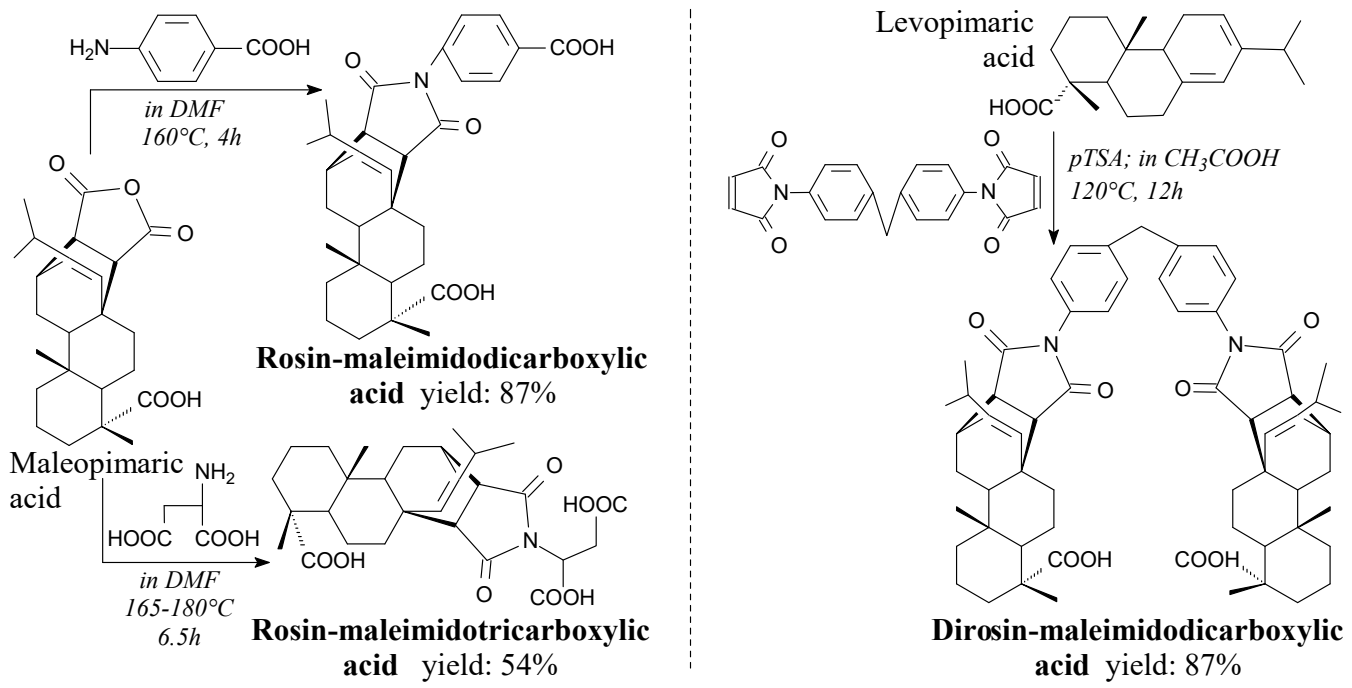

Scheme 23. Synthesis of rosin-maleimidodicarboxylic acids.

Rosin-polycaprolactone flexible dianhydride are solids with a melting point depending on the length of oligoester diol chain. They can be synthesized from rosin, oligocaprolactone diols and maleic anhydride according to Scheme 24 and using vacuum evaporation as a separation method [97]. Their application is bio-based curing agent for epoxy resins [97].

Tall-oil based polyol can be prepared from diethanolamine and tall oil containing up to $20 \mathrm{wt}$. $\%$ of rosin acids, according to Scheme 25, prior to vacuum evaporation of water [187]. It can be used as chain extenders in ureaurethane elastomers, improving their thermal resistance and storage moduls [187]. 


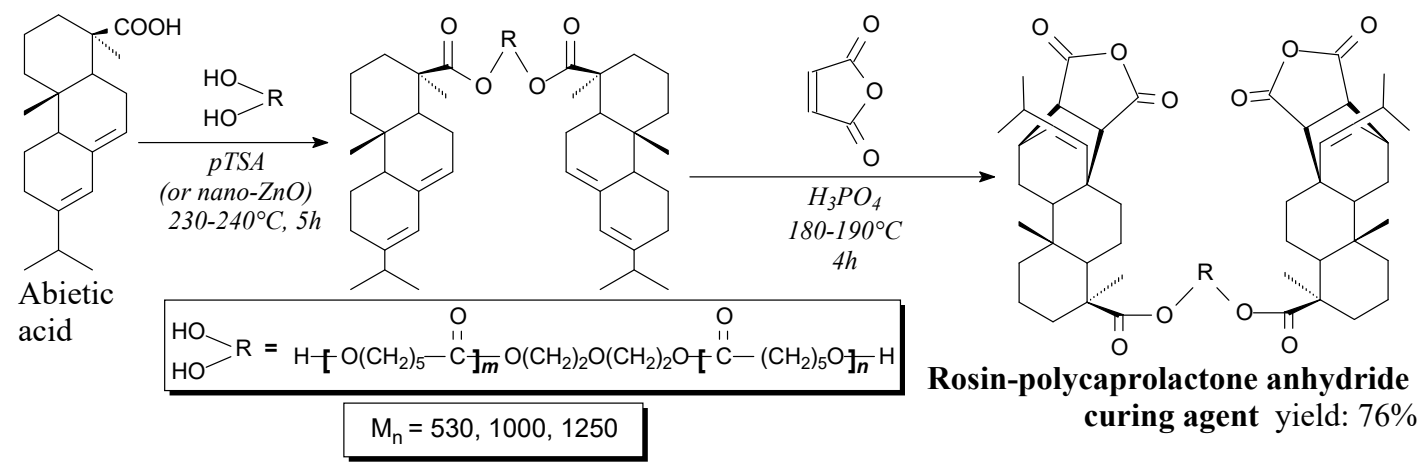

Scheme 24. Synthesis of rosin-polycaprolactone anhydride curing agent.
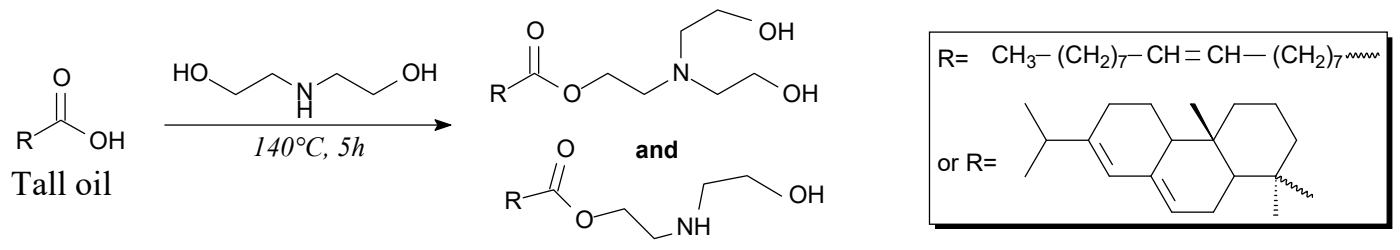

Tall oil-based polyol

Scheme 25. Synthesis of tall oil-based polyol.

\subsubsection{Surfactants}

Small/medium molecule rosin-based surfactants are ionic or non-ionic compounds that lower surface tension between different substances. In comparison with petrochemical counterparts, they are characterized by designable surface activity, affinity to many chemicals (especially cycloaliphatic and aromatic), non-toxicity, mild biocidal properties and enhanced thermal stability. Unfortunately, their syntheses are less well described than rosin-based resins and hardeners, e.g., reaction yields are often unavailable. Moreover, the use of unsustainable chemicals in the mentioned reactions noticeably decreases the "green" aspect of these rosin derivatives. Therefore, it is an urgent need to undertake applied studies on these compounds, as well as to find more sustainable preparation processes in order to increase TRL of this group of rosin derivatives.

Dehydroabietyl phosphate diester is a yellow viscous liquid. It can be prepared from dehydroabietyl chloride, decanediol, and polyphosphorus acid according to Scheme 26, prior to washing, vacuum evaporation and drying [140]. It can be used as highly-active surfactant [140], phosphorus source and crystal growth control agent in synthesis of hydroxyapatite [188].

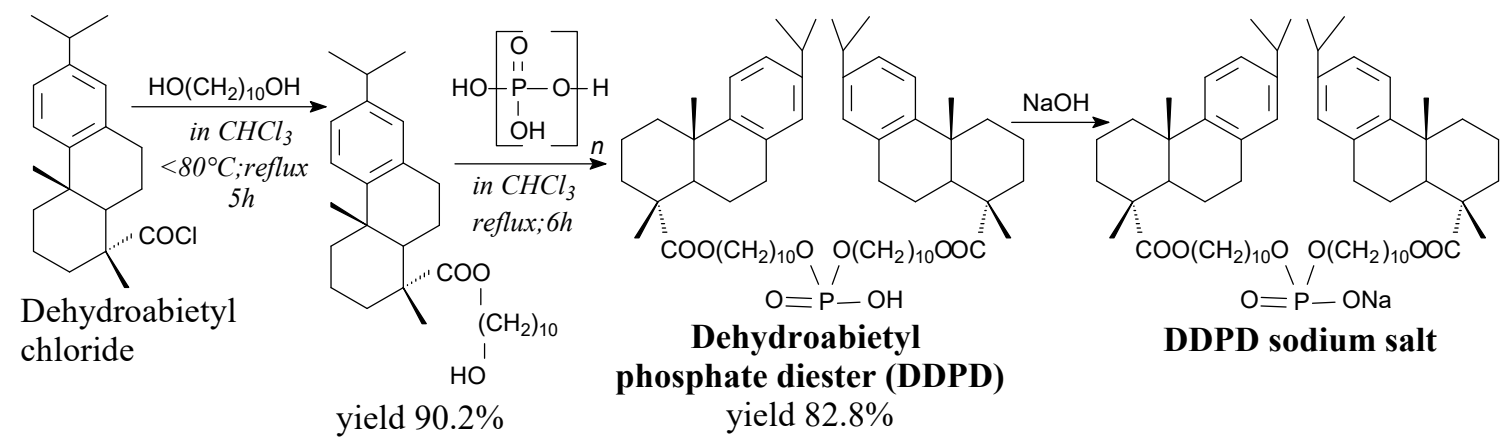

Scheme 26. Synthesis of dehydroabietyl phosphate diester sodium salt.

Rosin-based chloride can be prepared from maleated rosin and phosphorus trichloride according to Scheme 27, prior to evaporation [101]. It can be used as a substrate for synthesis of rosin-based ester amines [101]. 


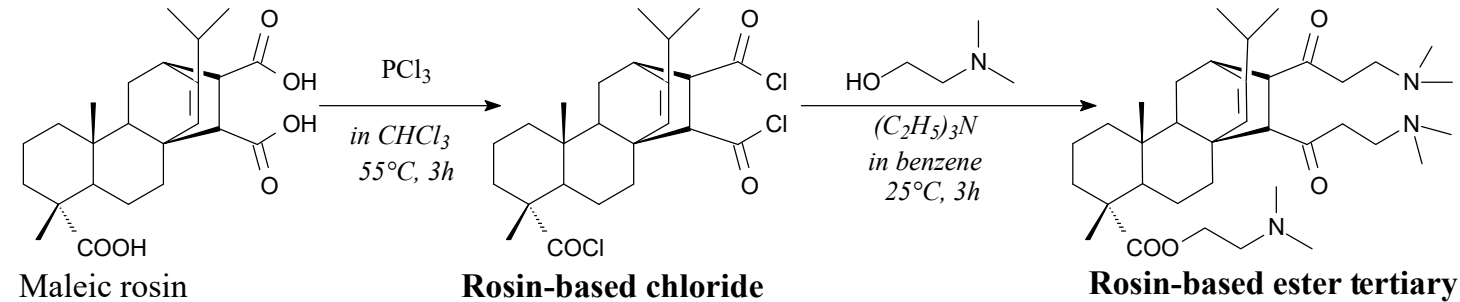
amine purity $81.18 \%$

Scheme 27. Synthesis of rosin-based ester tertiary amine.

Rosin-based ester tertiary amine can be prepared from rosin chloride and $N, N$-dimethyl ethanolamine according to Scheme 27, prior to washing, drying, extraction, evaporation and recrystallization [101]. Potential applications include drug carriers and surfactants. Its surface activity significantly increases in presence of rosin phosphate ester (Scheme 26) [101].

Solid $N$-dodecyl-maleimidepimaric acid (C12-MPA) can be prepared from maleopimaric acid and dodecylamine according to Scheme 28, prior to washing, drying, filtration, rotary evaporation and purification via column chromatography [100]. Sodium $\mathrm{N}$-dodecylmaleimidepimaric carboxylate is a product of C12-MPA neutralization using $\mathrm{NaOH}$, prior to evaporation, recrystallization and vacuum drying. It forms micelles of various shapes, depending on its concentration [102]. It can be used in oil extraction, cosmetics and industrial washing [100].

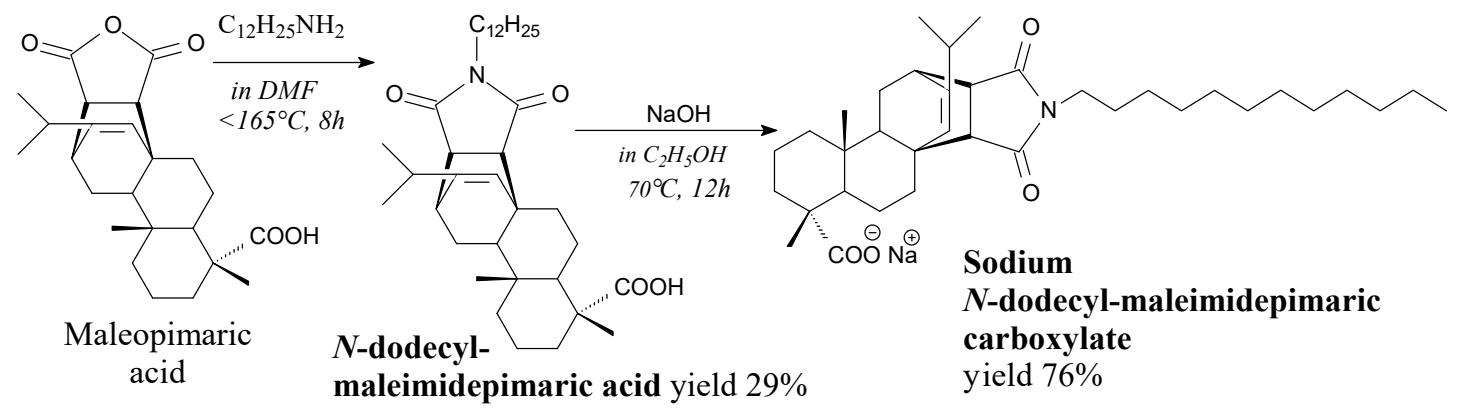

Scheme 28. Synthesis of sodium N-dodecyl-maleimidepimaric carboxylate.

Acrylpimaryl dichloride is an orange, sticky paste. It can be prepared from acrylpimaric acid according to Scheme 29, prior to solvent evaporation [128]. It can be used in synthesis of surfactants [128], herbicides [129], fungicides [189] and insecticides [190]

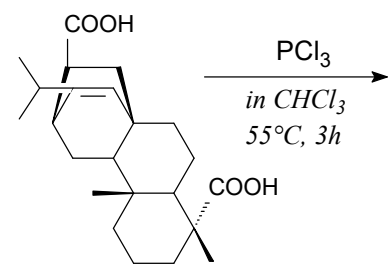

Acrylic rosin

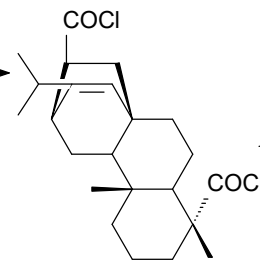

Acrylic rosin chloride yield $96 \%$
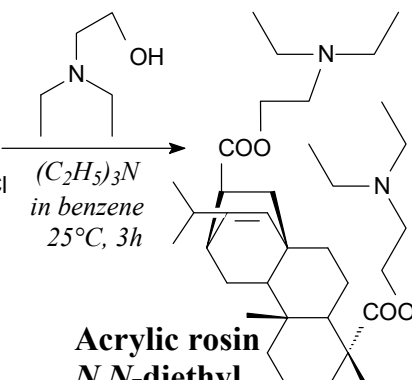

$N, N$-diethyl ethanolamine diester yield $87 \%$

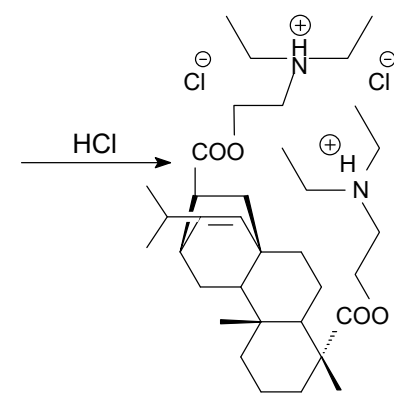

Acrylic rosin ester

diethylamine tertiary amine surfactant yield: $100 \%$

Scheme 29. Preparation of acrylic rosin ester diethylamine tertiary amine surfactant.

Acrylic rosin ester diethylamine tertiary amine surfactant is a sticky paste. It can be prepared from acrylpimaryl chloride, $N, N$-diethylethanolamine and hydrochloric acid according to Scheme 29 [128]. 
This product, in a mixture with soapnut saponin exhibits noteworthy surface activity and emulsification ability to apply in pharmacy, cosmetics and commodity chemicals [128].

Quaternary ammonium salts of rosin esters are yellow solids. They can be prepared from maleopimaryl chloride (described in Section 3.2.5) and N,N-diethylethanolamine with hexadecyl bromide, or epichlorohydrin with triethylamine, according to Scheme 30, and using such separation methods as vacuum distillation, filtration, washing, drying, extraction and recrystallization [104,191].

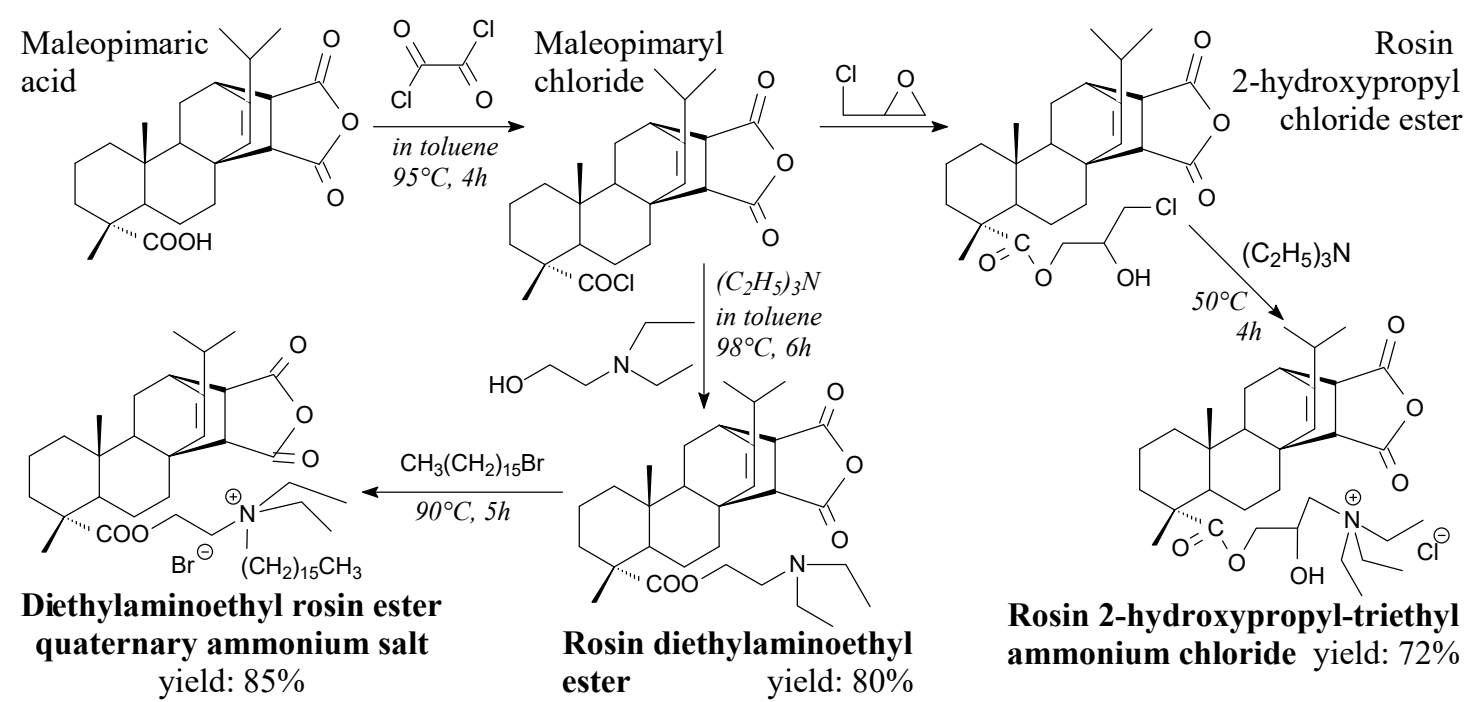

Scheme 30. Synthesis of quaternary ammonium salts of rosin esters.

Their potential applications include corrosion inhibitiors [104,191,192] dispersants for magnetite $\left(\mathrm{Fe}_{3} \mathrm{O}_{4}\right)$ nanoparticles [191,192] and inhibitors in protein aggregation processes [193-195]. In addition, a similar rosinyl triquaternary ammonium salt having antifungal activity was also reported [196].

Another approach to introduce quaternary ammonium moieties into rosin is presented in Scheme 31 [197]. As it can be seen, rosin bisquaternary ammonium chloride can be prepared from rosin, ethanol, fumaric acid and epoxy quaternary ammonium salt, and using such separation methods as washing and drying. Thus obtained gemini surfactant has good surface activity and antifungal activity against fungi responsible for wood decay [197].

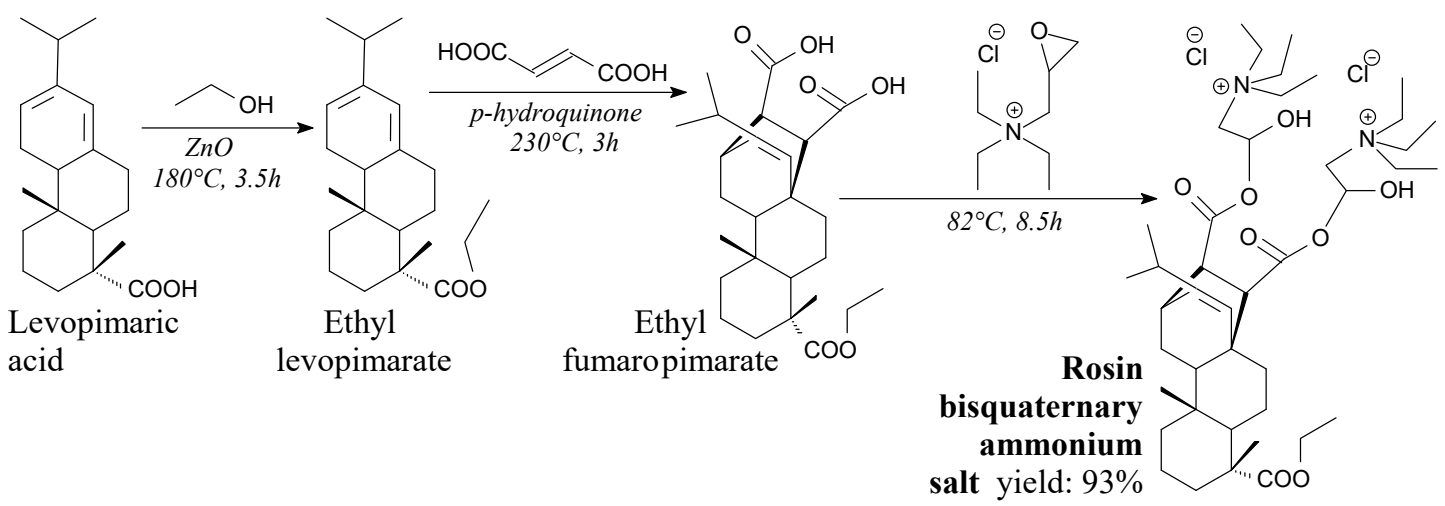

Scheme 31. Preparation of rosin bisquaternary ammonium salt.

Dehydroabietyltrimethyl ammonium bromide is a yellow solid. It can be prepared from dehydroabietylamine, formic acid and methyl bromide according to Scheme 32, and using such separation techniques as washing, extraction and evaporation, drying, vacuum distillation and recrystallization [158]. Such surfactant can be used for preparation of ordered porous titania [159], zirconia [198] or silica [158] with potential applications in catalysis and separation. 


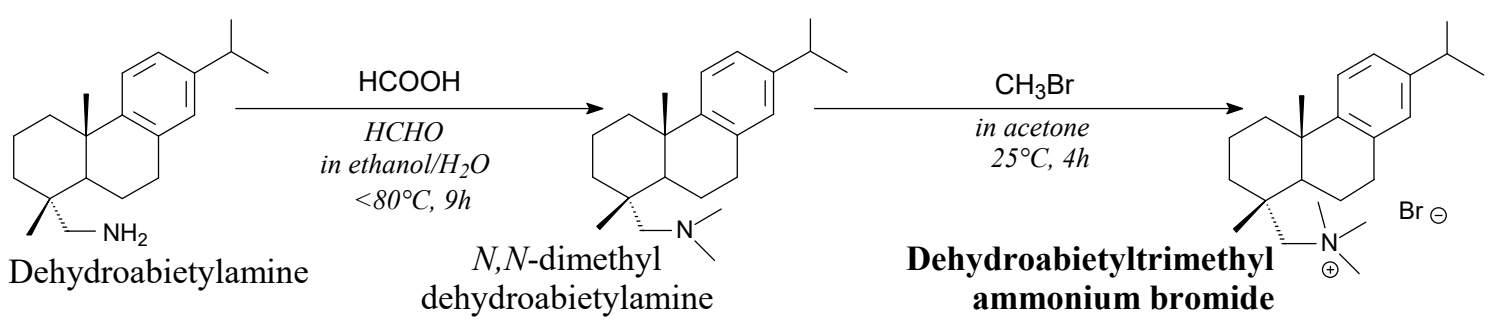

Scheme 32. Synthesis of dehydroabietyltrimethyl ammonium bromide.

Another rosin-based gemini surfactants $[143,199]$ can be prepared from dehydroabietyl chloride, 3 -(dimethylamino)-1-propylamine and $\alpha, \omega$-dibromoalkanes according to Scheme 33. The product separation methods include column chromatography, vacuum drying and recrystallization from ethanol/ethyl acetate [143]. They can be used in preparation of three-dimensional mesoporous materials for separations, catalysis and drug delivery [143].

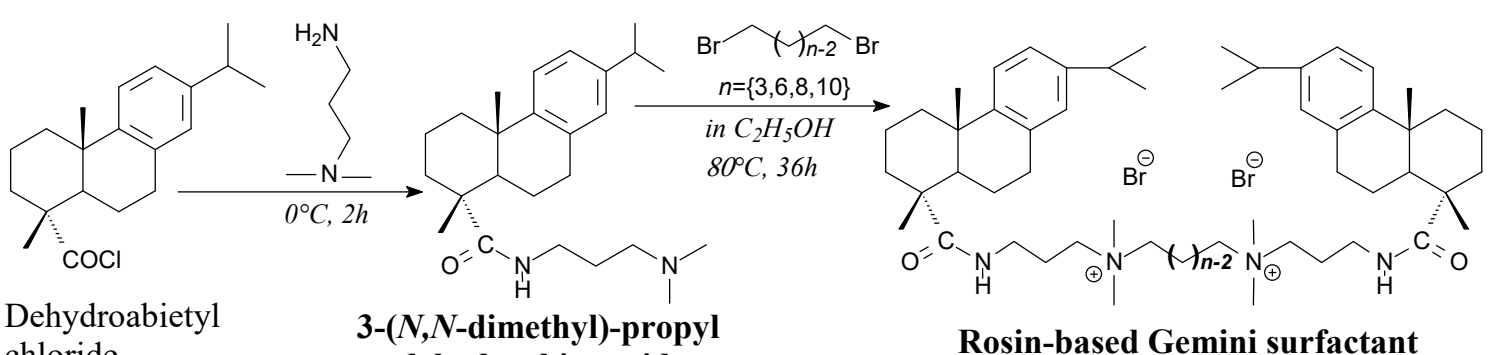
chloride dehydroabietamide

Rosin-based Gemini surfactant

Scheme 33. Synthesis of rosin-based gemini surfactant.

Rosin-based cyclic tricarbonate is a brown solid. It can be prepared from maleopimaric acid triglycidyl ester and carbon dioxide according to Scheme 34, prior to washing and vacuum drying [132]. Its applications include synthesis of quaternary ammonium salt derivatives [132] and non-isocyanate polyurethanes [200]. Rosin-based carbamate group-containing quaternary ammonium salt derivatives are brown solids. They can be prepared from rosin-based cyclic tricarbonate, $\mathrm{N}, \mathrm{N}$-dimethylaminopropylamine and alkyl bromides according to Scheme 34, and using vacuum drying and recrystallization [132]. They exhibit strong antimicrobial properties [132].

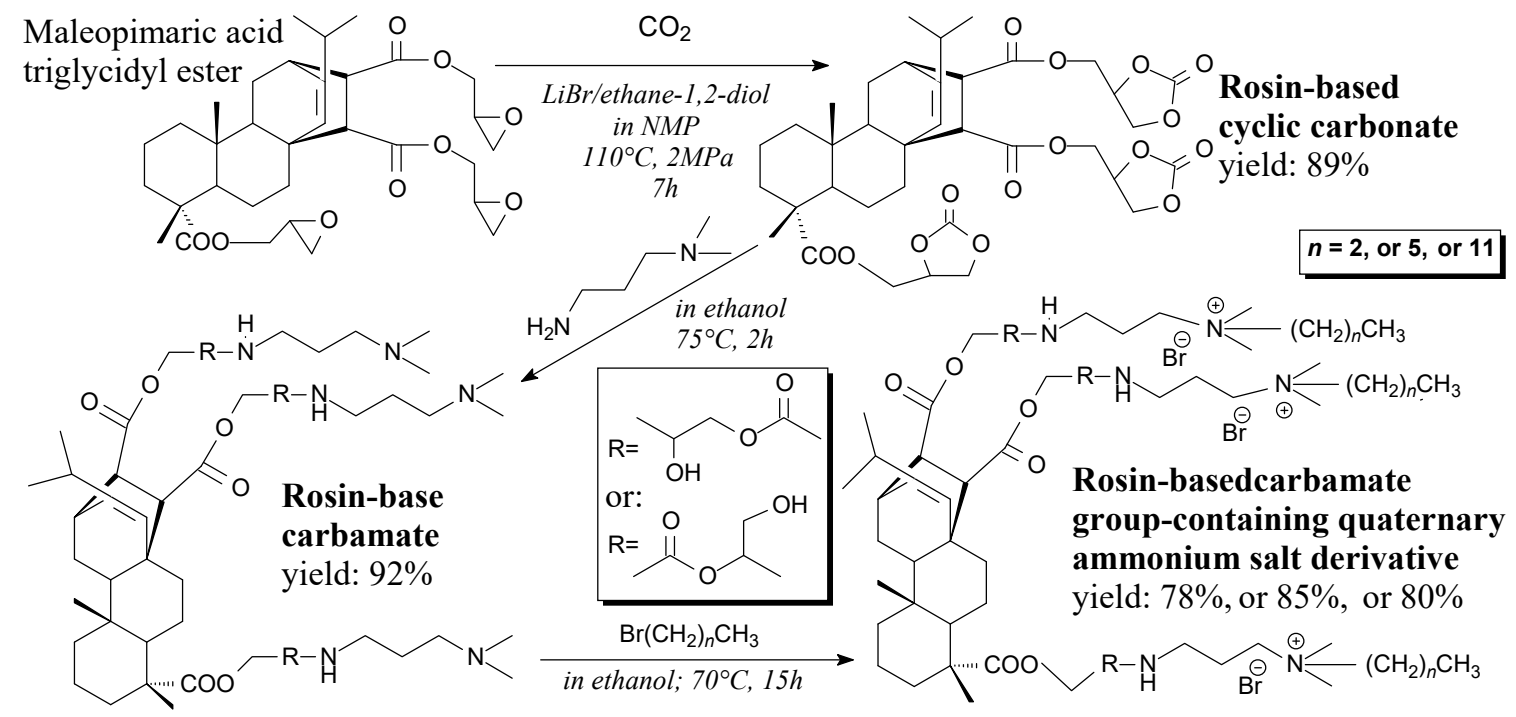

Scheme 34. Synthesis of rosin-based carbamate and carbamate group-containing quaternary ammonium salt derivatives. 
Maleopimaric acid diethanolamide is a solid. It can be synthesized from maleopimaric acid and diethanolamine according to Scheme 35 [103]. It can be applied as a dispersant and a viscosity depressant in coal-water slurry [103].

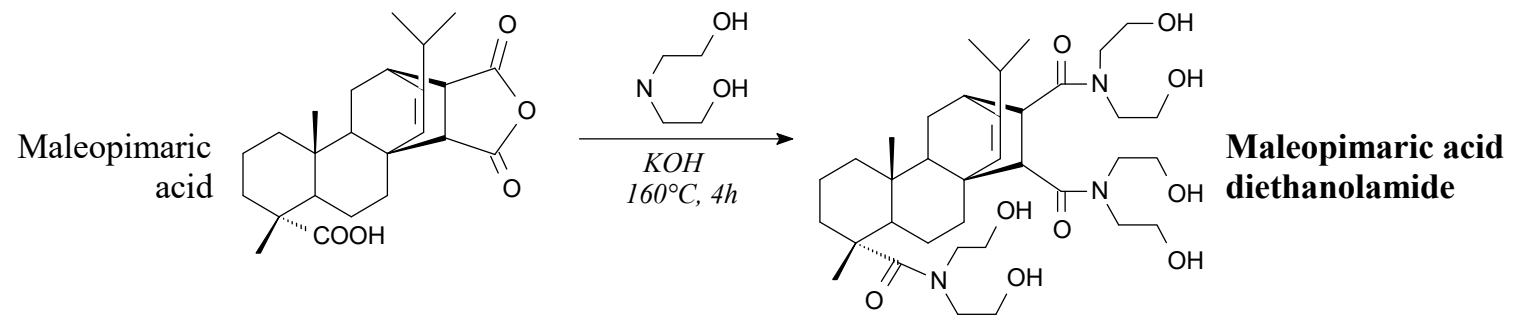

Scheme 35. Synthesis of maleopimaric acid diethanolamide.

Acrylpiamric acid salts of calcium and zinc are solids. They can be prepared from acrylpimaric acid, sodium hydroxide and calcium chloride or zinc sulfate according to Scheme 36 and using such separation methods as washing, filtration and drying [137]. They can be used as a stabilizer of poly(vinyl chloride) showing better thermal stability than commercial Ca/Zn stearate [137].

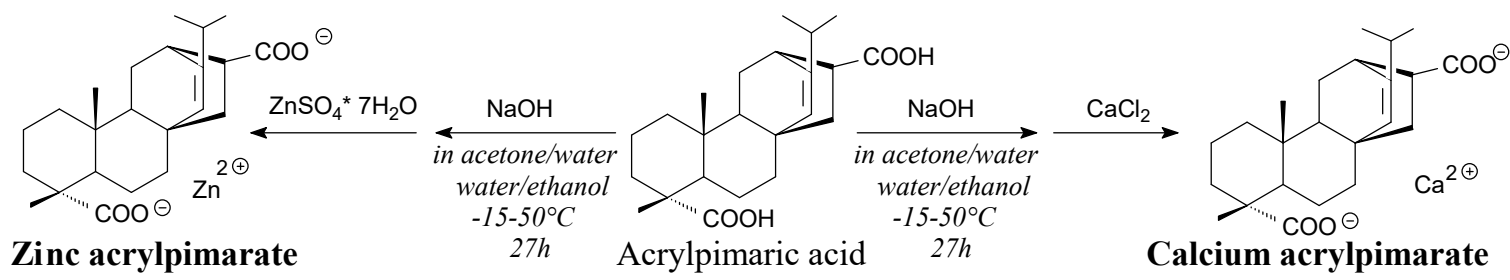

Scheme 36. Synthesis of acrylpimaric acid divalent metal salts.

Rosin-derived binapthyl-appended 22-crown-6 ether can be synthesized from methyl maleopimarate, sodium borate and sodium hydride according to Scheme 37 [184]. It can be used in highly enantioselective reactions because of its amines enantiomeric recognition ability [184]. Very similar compounds can be also synthesized directly from maleopimaric or fumaropimaric acid [201].

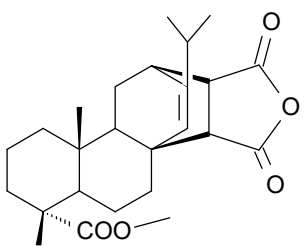

Methyl maleopimarate

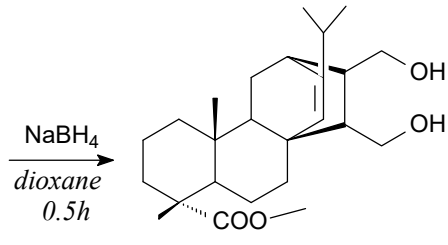

Rosin-based diol (yield: 53\%)

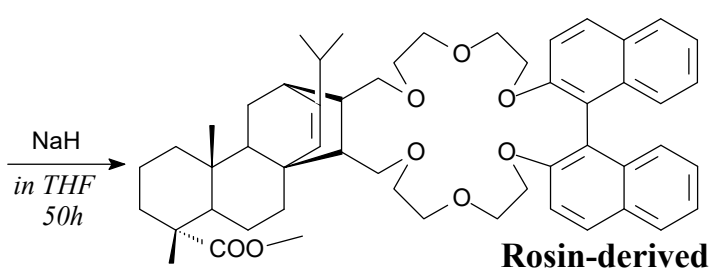

binaphthyl-appended 22-crown-6 ether

Scheme 37. Synthesis of rosin-derived binapthyl-appended 22-crown-6 ether.

\subsubsection{Biologically Active Compounds}

Pure abietic acid isolated from rosin and its derivatives exhibit many potential activities of interest to the pharmaceutical industry, for example, antitumor, anti-inflammatory, antimycotic and anti-arteriosclerotic properties and uses in treating digestive canal, acute and chronic gastritis, and erosive gastritis, allergy, asthma, arthritis and psoriasis [202]. In this subsection rosin-based chemicals with main applications as biologically active compounds can be found. They include both medications and biocides. Their synthetic routes are usually characterized in detail and, from the chemical point of view, their TRLs are rather high. It is worth noting, that although the sustainability of their syntheses is usually worse than for other rosin derivatives (due to the necessity of using more 
dangerous chemicals), it is still better than their petrochemical counterparts (thanks to the use of bio-based rosin as a main substrate).

Methyl dehydroabietate is a white solid. It can be prepared from dehydroabietyl chloride and methanol according to Scheme 38, prior to vacuum evaporation and recrystallization [141]. It can be used as a substrate in the synthesis of antimicrobial agents and medicines $[141,150]$.

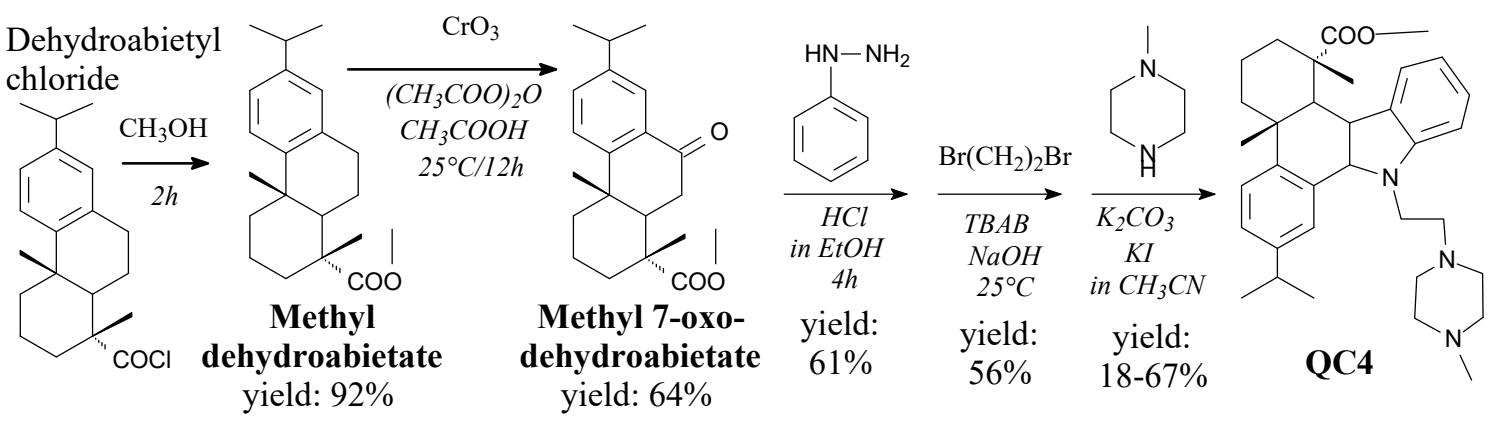

Scheme 38. Synthesis of dehydroabietic derivative QC4.

Methyl 7-oxodehydroabietate is a yellow oil. It can be prepared from methyl dehydroabietate and chromium trioxide according to Scheme 38, followed by extraction, drying and column chromatography [141]. It can be used as a substrate in synthesis of antimicrobial agents and medicines $[141,150]$.

Dehydroabietic acid derivative QC4 can be prepared from methyl 7-oxodehydroabietate, phenylhydrazine hydrochloride, 1,2-dibromoethane and $N$-methyl piperazine, according to Scheme 38 [141,150]. It shows antimicrobial properties [150] and, moreover, induces gastric cancer cell death via oncosis and apoptosis [151]. Another dehydroabietic acid derivative QC2 is reported to be able to inhibit skin cancer cell lines [203].

$\mathrm{N}$-(2-methyl-naphthyl)maleopimaric acid diimides and their methyl esters are white solids (m.p. $215-290^{\circ} \mathrm{C}$ ). They can be synthesized from maleopimaric acid, 2-methyl-1-naphtylamine and dimethyl sulfate according to Scheme 39, and using separation methods such as extraction, washing, drying, evaporation and recrystallization [106,107]. They show significant antitumor cytotoxicity against several human cancer cell lines, especially NCI cells and MGC-803 cells [106].

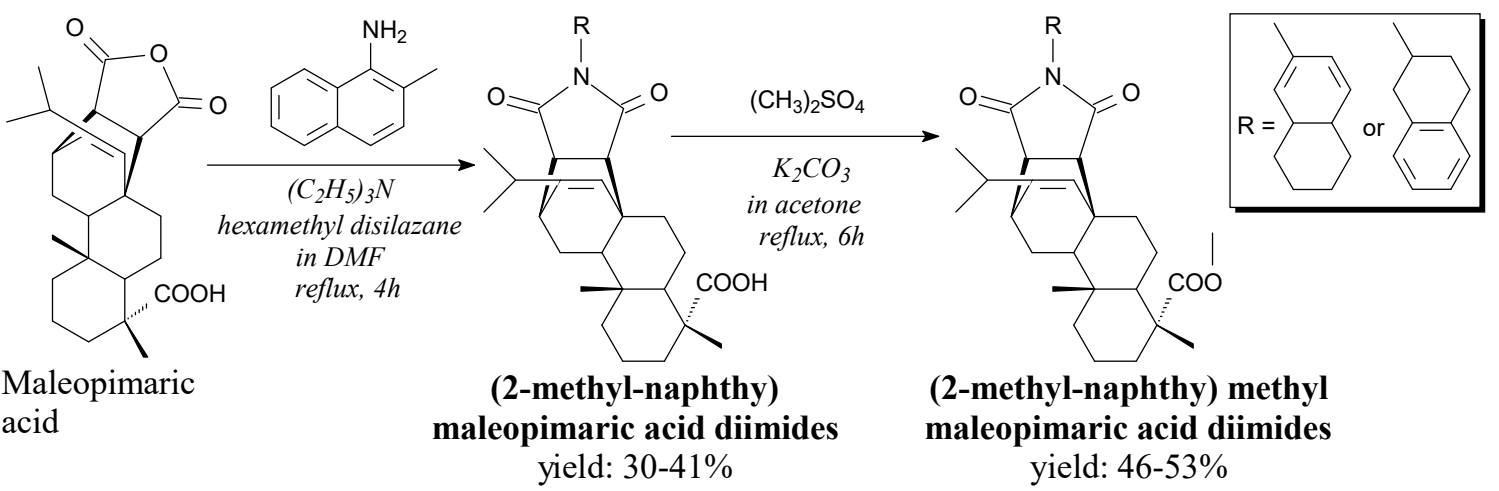

Scheme 39. Synthesis of N-(2-methyl-naphthyl)maleopimaric acid diimides.

Anticancer effects of various rosin derivatives, especially thioureas, were also investigated; they showed significantly cytotoxicity toward diverse human carcinoma cell lines [108].

Thiadiazole group-containing amides of dehydroabietic or acrylpimaric acids can be prepared from adequate rosin acid, thiosemicarbazide and an acyl chloride according to Scheme 40, and using such separation methods as filtration, vacuum drying, recrystallization and column chromatography [130]. They can be potentially applied as insecticides [130,190]. 


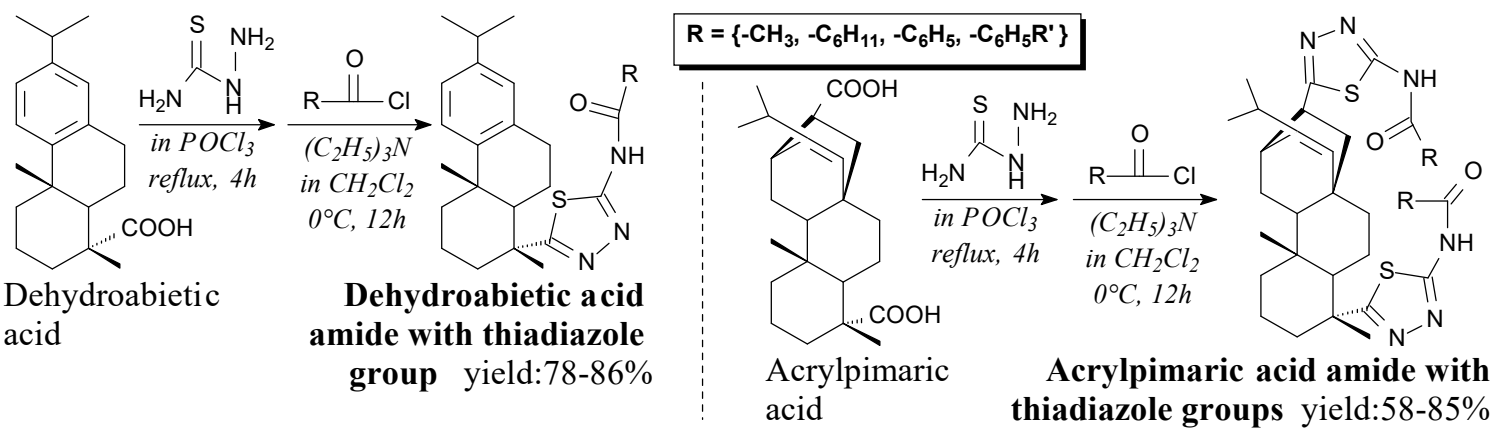

Scheme 40. Synthesis of rosin acid amides with thiadiazole groups.

Acrylpimaric acid-based aromatic diacylthioureas can be prepared from acrylpimaryl dichloride, potassium thiocyanate and aromatic amines according to Scheme 41, prior to vacuum evaporation and recrystallization [129]. They may be applied as botanical herbicides showing higher activity than similar dicarboxamide, dihydrazone and diimide compounds [129]. Moreover, some acrylpimaryl diimides possess antibacterial activities against Gram-positive Staphylococcus aureus and Gram-negative Escherichia coli [204]. Furthermore, some acrylpimaryl dicarboxamides show antibacterial properties against E. coli, whereas their activity against Gram-positive bacteria was significantly lower [205].

\section{Acrylpimaryl diacarboxamide compound yield: $58-85 \%$}

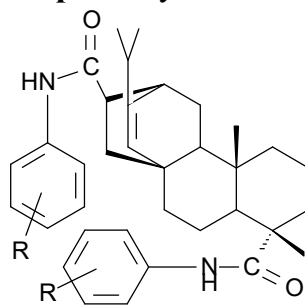

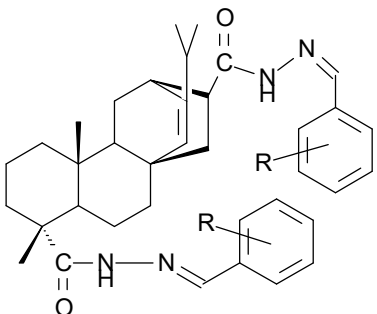

Acrylpimaryl dihydrazone compound yield: $45-60 \%$
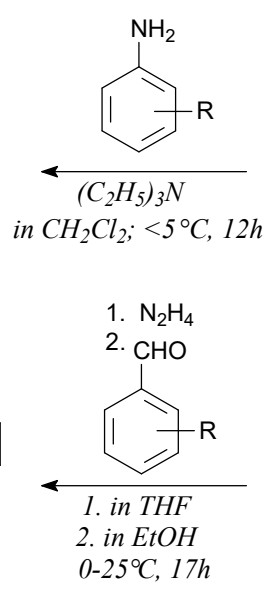

chloride

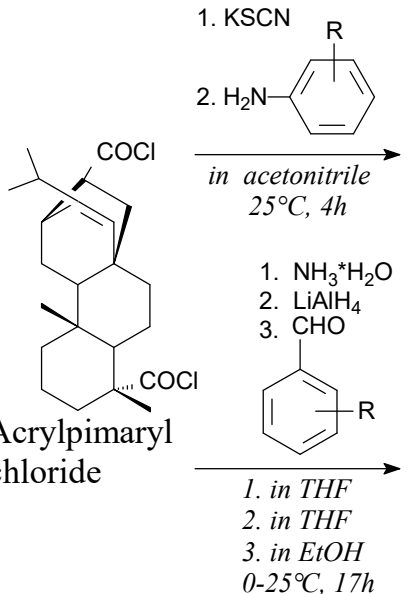

Acrylpimaryl
Acrylpimaryl diacylthiourea compound yield: $60-77 \%$

$$
\mathrm{O}
$$

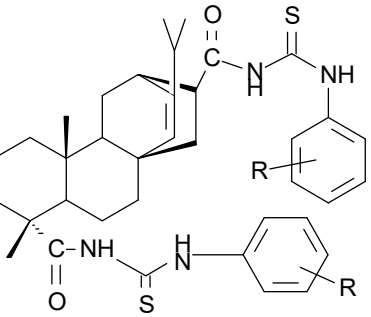

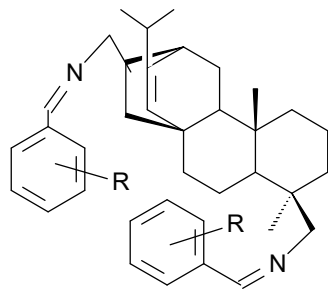

Acrylpimaryl diimide compound yield: $22-59 \%$

Scheme 41. Synthesis of acrylpimaric acid-based aromatic diacylthioureas, dicarboxamides, dihydrazones and diimides.

Solid acrylpimaryl quaternary ammonium salts can be synthesized from acrylpimaryl acid, oxalyl chloride, epichlorohydrin and volatile tertiary amines according to Scheme 41 and using such separation methods as vacuum distillation, extraction and recrystallization [189]. They show fungicidal activity and can be applied in wood preservation [189]. Very similar acrylpimaryl materials that can be applied as surfactants were also prepared [133]. Another fungicidal rosin-based materials can be prepared in similar way from rosin, epichlorohydrin and amines [134-136]. Maleopimaryl chloride is a yellowish solid. It can be prepared from maleopimaric acid and oxalyl (or thionyl) chloride, according to Scheme 30 or Scheme 42, prior to vacuum distillation and washing [104,105]. It can be used as an intermediate in preparation of surfactants [104] or fungicides [105]. 


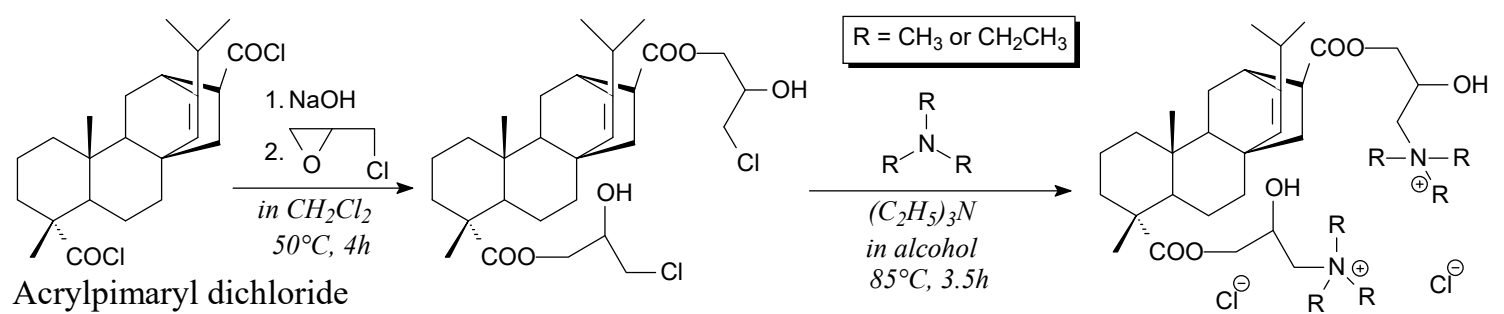

Acrylpimaryl quaternary ammonium salt yield: $71-82 \%$

Scheme 42. Synthesis of acrylpimaryl quaternary ammonium salts.

Maleated rosin-based dithiourea compounds are yellow solids (m.p. $162-216{ }^{\circ} \mathrm{C}$ ). They can be prepared from maleated rosin acyl chloride, hydrazine and substituted benzoyl isothiocyanates, according to Scheme 43, and using separation methods such as rotary evaporation, recrystallization and column chromatography [105]. They can be potentially used as fungicides [105].

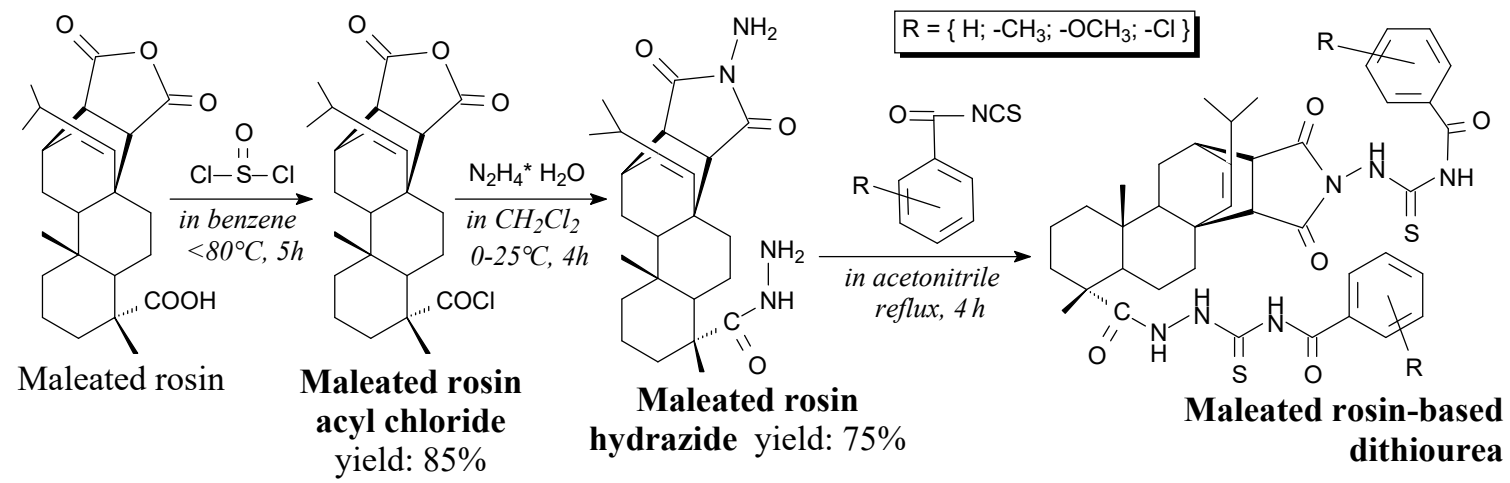

Scheme 43. Synthesis of maleated rosin-based dithiourea compounds.

Glucose dehydroabietate can be prepared from dehydroabietic acid and glucose according to Scheme 44 prior to vacuum distillation, filtration and washing [206]. Its potential application is as a surfactant in food industry [206].

Dehydroabietic<smiles>CC(C)c1ccc2c(c1)CCC1C(C)(C)CCCC21C(=O)O</smiles>

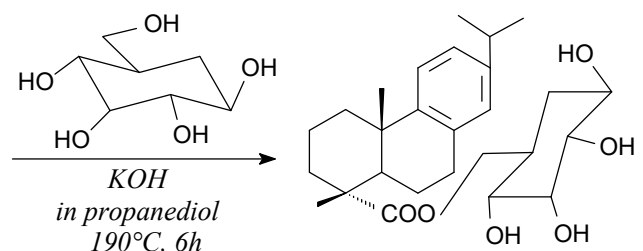

$190^{\circ} \mathrm{C}, 6 \mathrm{~h}$
Glucose dehydroabietate yield: $51 \%$

Scheme 44. Preparation of glucose dehydroabietate.

Acrylic rosin cyclic diamide is a solid. It can be prepared from acrylpimaric acid and diethylene triamine according to Scheme 45 prior to washing and drying [131]. It can be used as a fungicide for wood preservation [131].

Acrylpimaric acid

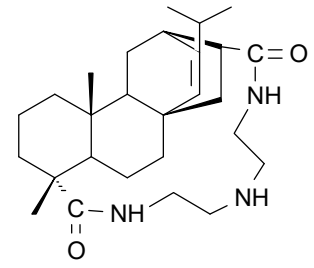

$\mathrm{O}$
Acrylic rosin cyclic diamide

Scheme 45. Preparation of acrylic rosin cyclic diamide. 


\subsubsection{Other Small/Medium Molecule Products}

Hydroabietic acid can be prepared from rosin and hydrogen using palladium/SBA-15 mesoporous silica catalyst, according to Scheme 46 [207]. This catalyst is more efficient than others [208,209] Its applications include oxidation-resistant solvent-borne tackifiers and coatings, a substrate for esterification with glycerol [210], additives for polyvinylidene difluoride binders for lithium titanium oxide anodes [76]. It can be used in high-performance liquid epoxy resins [83], for synthesis of high adhesion polyurethane acrylate [173]. It is noteworthy, that non-catalytic decarboxylation of rosin can take place at temperatures above $200{ }^{\circ} \mathrm{C}$, and the main product of such decomposition is norabieta-8,11,13-triene [211].
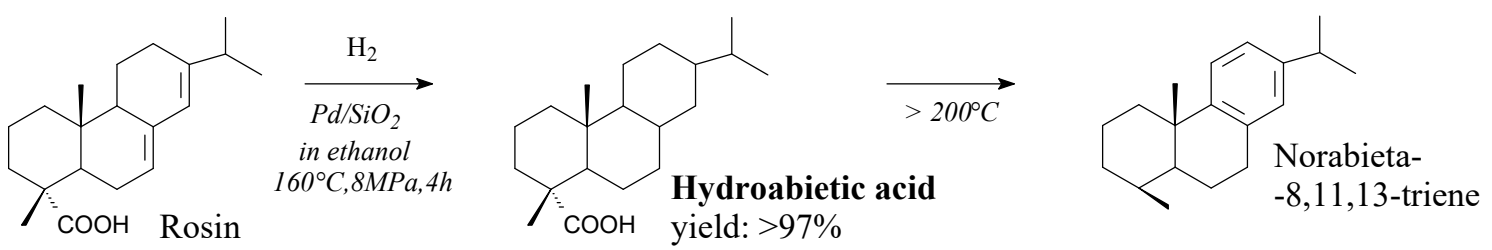

Scheme 46. Hydrogenation of rosin to hydroabietic acid.

Rosin-based standard-quality biodiesel can be prepared in a catalyst-free process from dark-grade rosin, heavy turpentine and supercritical methanol in supercritical $\mathrm{CO}_{2}$ as a green medium. Yields $>93 \%$ were obtained after $3 \mathrm{~h}$ at $340{ }^{\circ} \mathrm{C}$, under a pressure of $11 \mathrm{MPa}$ [212]. Yield of $>85 \%$ can be achieved using Pt/mesoporous aluminosilicate catalyst after $4 \mathrm{~h}$ at $300-350{ }^{\circ} \mathrm{C}, 5 \mathrm{MPa}$ [213]. A yield $>99 \%$ can be achieved using Ni/layered double hydroxide catalyst after $<2 \mathrm{~h}$ at $190^{\circ} \mathrm{C}, 5 \mathrm{MPa}$ [214]. Catalytic cracking of rosin is also possible to carry out using acid-activated montmorillonite [215].

Acrylpimaryl nitrile can be prepared from levopimaric acid and acrylonitrile according to Scheme 47, prior to extraction, filtration and precipitation [216,217]. It can be used in synthesis of diacrylpimaryl ketone and acrylpimaryl amidoxime [217].

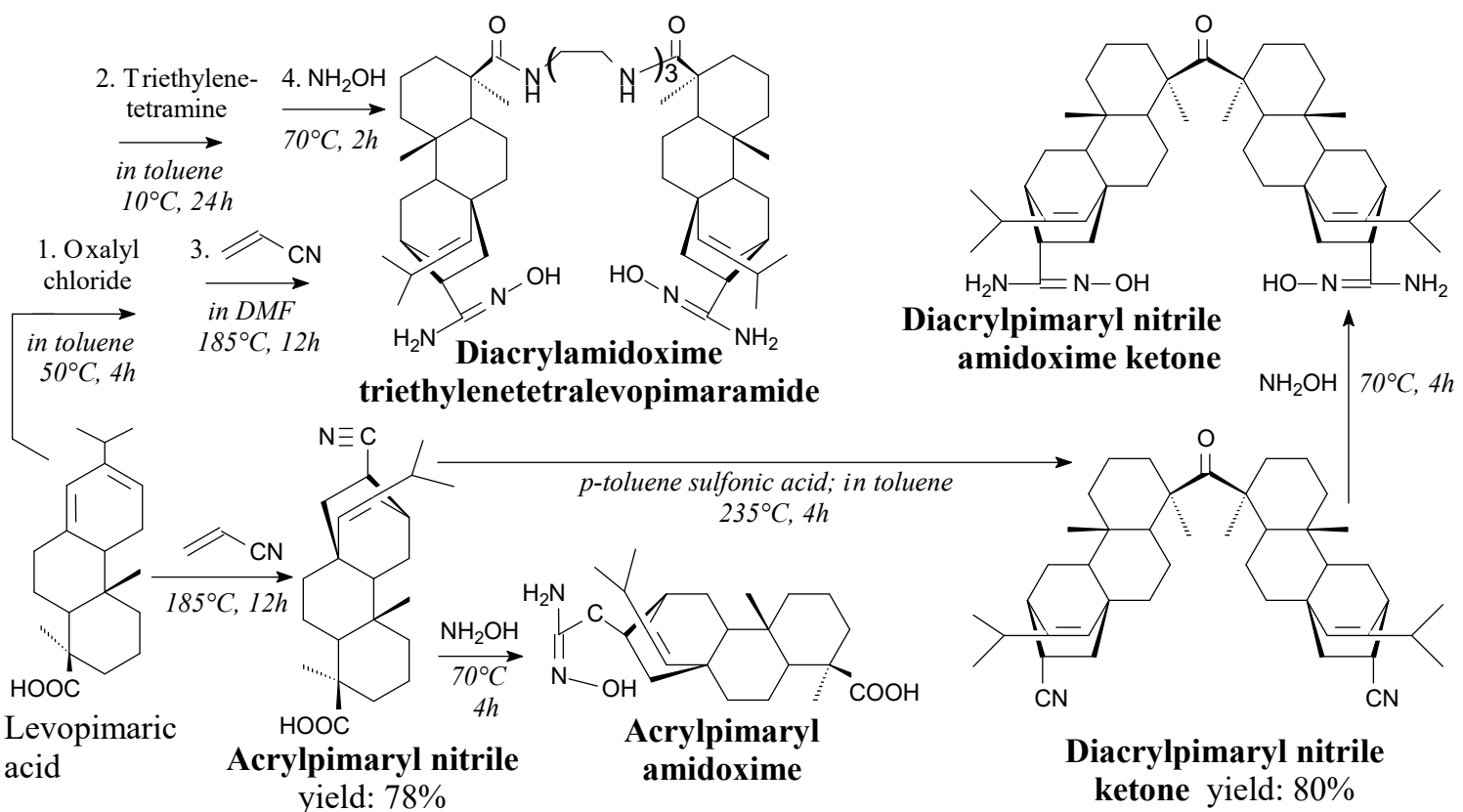

Scheme 47. Synthesis of acrylpimaryl nitrile and acrylpimaryl amidoximes.

Acrylpimaryl nitrile amidoximes can be prepared from adequate acrylpimaryl nitriles and hydroxylamine according to Scheme 47 , prior to precipitation, washing, filtration and drying $[217,218]$. 
They can be used to prepare bioactive thin films filled by magnetite nanoparticles for oil spill collecting [217] and thorium ions removal [218].

Rosin-oil dimer acids mixture can be prepared from rosin and industrial fatty oils according to Scheme 48, prior to washing and rotary evaporation [219]. It can be used for preparation of a liquid thermal stabilizer [219]. It is noteworthy, that dimerized rosin is usually produced separately and can be applied in acrylic adhesives $[220,221]$ to improve their wetting, adhesion and thermal stability [220].

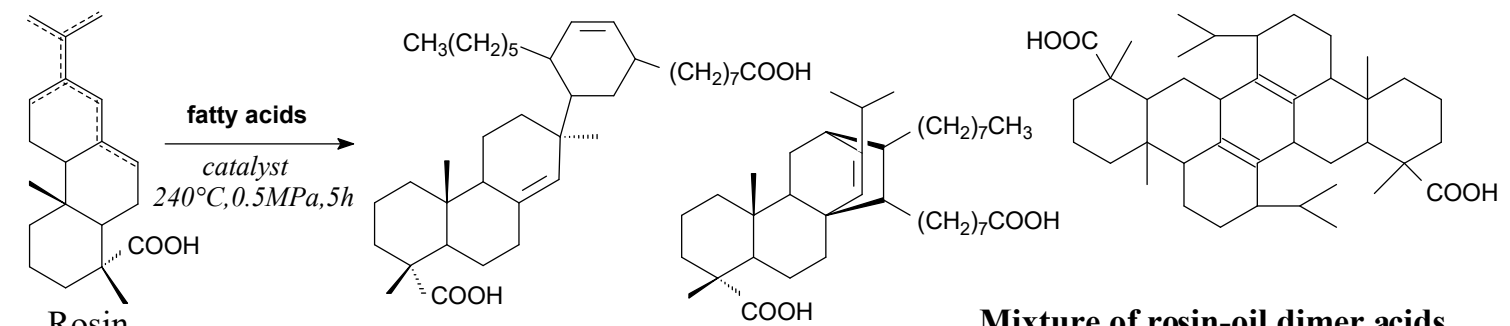

Rosin

Scheme 48. Preparation of rosin-oil dimer acids mixture.

Solid rosin-based chain extender for polyurethanes can be synthesized from rosin-maleimidodicarboxylic acid, thionyl chloride and ethylene glycol, according to Scheme 49, and using such separation methods as vacuum distillation, washing and evaporation [186]. Its application in shape memory polyurethanes improves shape recovery at $>1000 \%$ strain up to $96 \%$ [186].

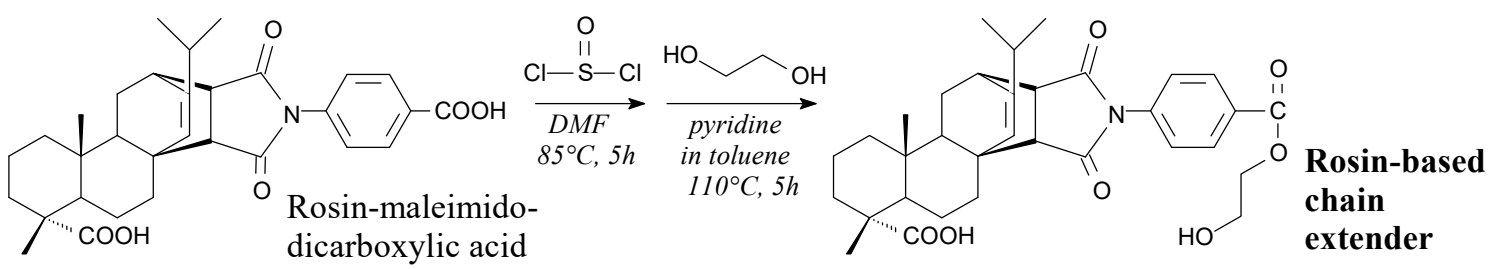

Scheme 49. Synthesis of rosin-based chain extender for polyurethanes.

Chiral thioureas and thiouronium salts containing dehydroabietyl groups are well characterized white or yellow solids [222]. They can be prepared from chiral amines (including dehydroabietylamine), carbon disulfide and butyl halides according to Scheme 50 and using such separation methods as filtration, washing, vacuum drying, evaporation and column chromatography [222]. They can be useful for the physical separation of racemic mixtures [222]. Moreover, rosin-derived thioureas can be used as enantioselective catalysts for many reactions [12]. In recent years these were: Michael addition [223,224], tandem Michael/cyclization sequence [225], asymmetric Michael/hemiketalization [226], asymmetric aza-Henry reaction [227], asymmetric tandem reaction [228], Mannich reaction [229,230], Friedel-Crafts alkylation [231], enantio- and diastereoselective asymmetric addition [232], as well as synthesis of chiral amines [233] or $N$-protected $\beta$-amino malonates [234]. In recent studies rosin-derived thioureas are dominant majority of all investigated rosin-derived catalysts. They are not explored further in the current article because they are the subject of a comprehensive review publication [12]. For now, reports on another rosin-based catalysts are rare [235-237].

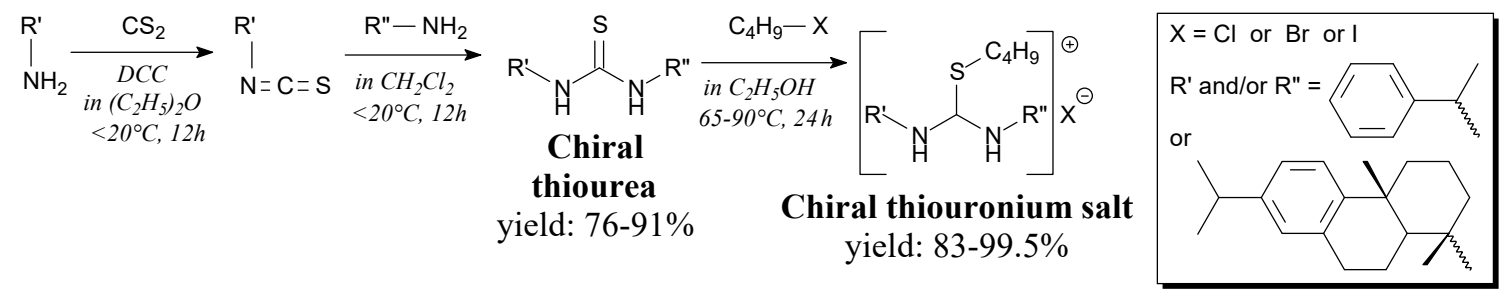

Scheme 50. Synthesis of chiral thioureas and their thiouronium salts. 
Optically pure rosin-based chiral alcohols and their phosphorus derivatizing agents are white solids. They can be synthesized from maleopimaric acid in two main ways according to Scheme 51 and using such separation methods as washing, filtration, drying, evaporation, and recrystallization [113]. They can be used in ${ }^{31} \mathrm{P}-\mathrm{NMR}$-based determination of enantiomeric excess in solutions containing chiral alcohols and amines [113].

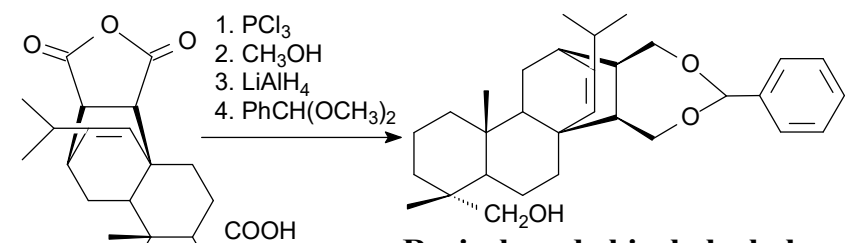

Rosin-based chiral alcohols yield: $53-65 \%$

Maleopimaric acid

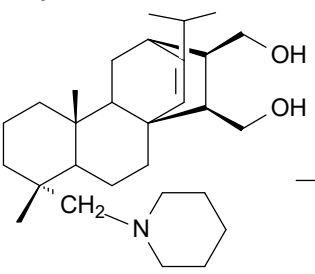

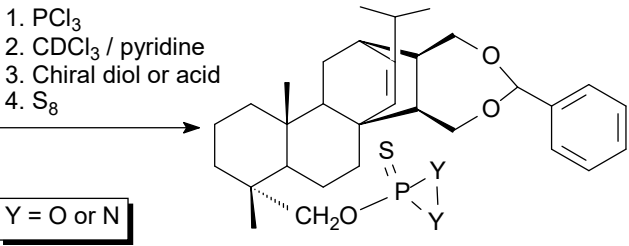

Rosin-based chiral phosphorus derivatizing agens

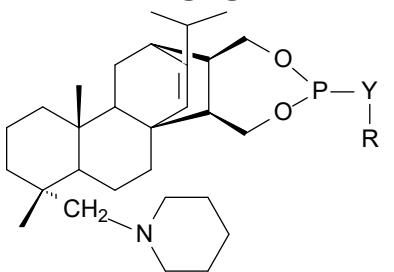

Scheme 51. Synthetic routes of rosin-based chiral alcohols and phosphorus derivatizing agents.

Rosin-based molecular glass photoresists can be prepared from maleopimaric acid, hydroxylamine, 2-diazo-1-naphthoquinone-4-sulfonyl chloride and unsaturated compounds: vinyl ethyl ether, or dihydropyran, or cyclohexyl vinyl ether, according to Scheme 52 and using such separation methods as filtration, washing and vacuum drying [114]. These materials can be applied in photolithography [114].

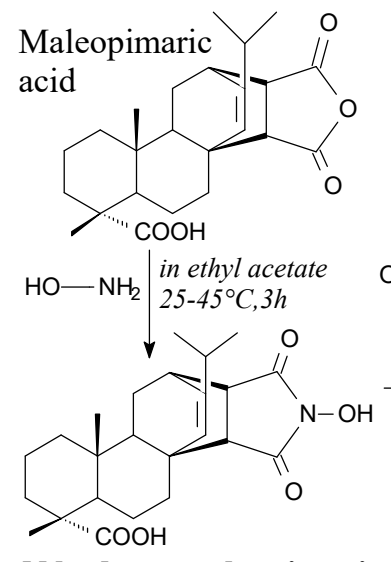

$\mathrm{N}$-hydroxymaleopimarimide (NHMPI) yield: $70 \%$

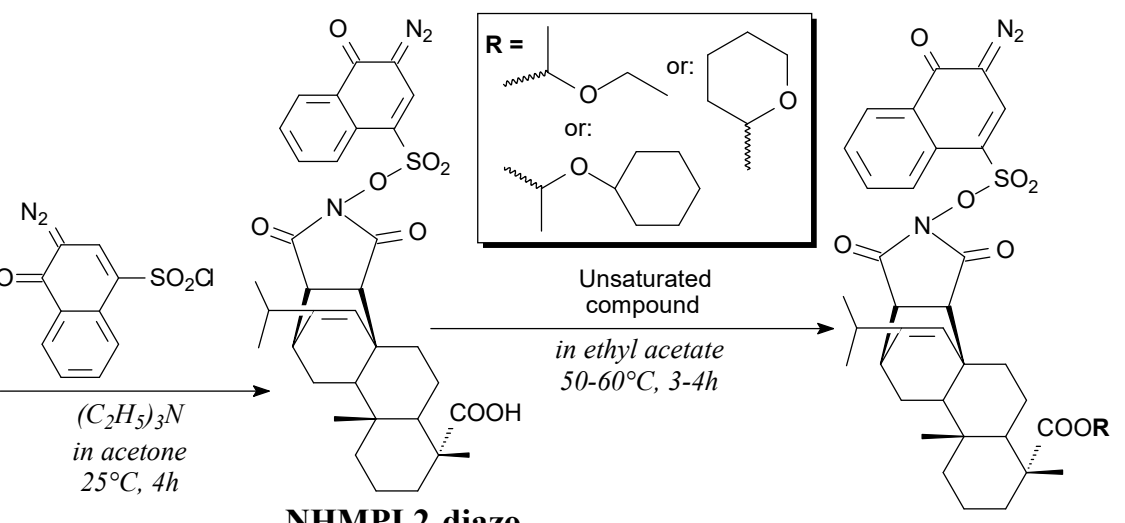

NHMPI 2-diazo-

1-naphthoquinone-

4-sulfonate yield: $94 \%$
Rosin-based molecular glass compound yield: $90 \%$

Scheme 52. Synthesis of rosin-based molecular glass compound.

\subsection{Macromolecular Compounds}

This section describes rosin-derived macromolecular compounds with repeated units typical of macromolecules. It contains polymers, oligomers, macroinitiators and polymer functionalized materials. Additionally, some small/medium molecule compounds, which are not presented in the previous section, but necessary to obtain appropriate macromolecules, are described here. Non-toxicity, natural origin, low price, rigid structure, hydrophobicity, excellent thermal properties, anticorrosive performance, mild biocidal properties and stickiness are the most attractive reasons to use rosin derivatives in the preparation of polymer materials. A disadvantage of these processes in comparison 
with petrochemical counterparts is the relatively lower reactivity of rosin derivatives resulting from the steric hinderance of the diterpene skeleton and the usually lower purity of rosin-based intermediates, as discussed in Section 3.2.1. As a result, rosin-based polymer materials are usually characterized by distinct polydispersity and molecular weights rather far from their theoretical values. Therefore, their TRL is lower than for small/medium molecule compounds of rosin. It is noteworthy, that compared to non-renewable counterparts, the use of rosin significantly increases the sustainability of preparation processes according to Green Chemistry rules, so there is still high demand for basic and applied research in this field.

\subsubsection{Polymers for Biomedical Applications}

Poly(ethylene glycol) rosin esters are oligomers, which can be prepared from rosin, polyethylene glycol and maleic anhydride, according to Scheme 53 prior to drying at $40-70{ }^{\circ} \mathrm{C}[81,238]$. Proposed applications include shells for controlled drug delivery [238,239] and dental films for periodontitis treatment [240]. Moreover, maleopimaric acid PEG esters can show carbon steel corrosion protection properties [241].

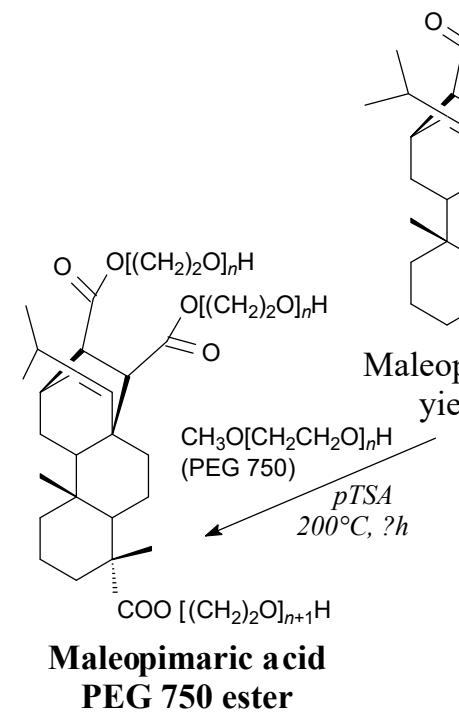

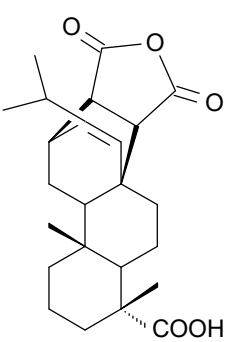

Maleopimaric acid yield: $42 \%$<smiles></smiles>

Levopimaric acid PEG 400 ester

$$
\mathrm{HO}\left(\mathrm{CH}_{2} \mathrm{CH}_{2}\right)_{9} \mathrm{H} \uparrow \mathrm{Zn}^{2+}
$$$$
\begin{array}{lll}
(\mathrm{PEG} 400) & 220^{\circ} \mathrm{C}, 5 \mathrm{~h}
\end{array}
$$

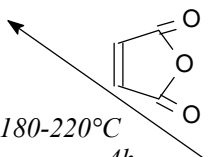

$4 h$

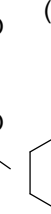

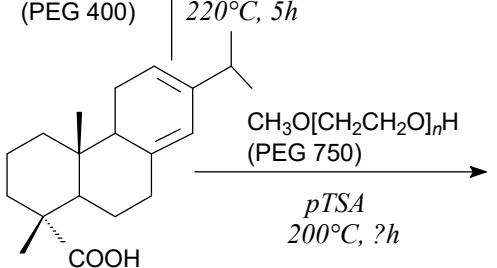

Levopimaric acid

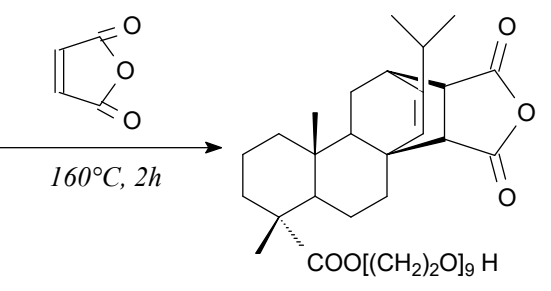

Maleopimaric acid PEG 400 ester

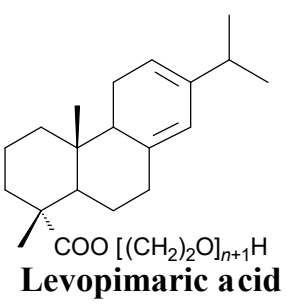

PEG 750 ester

Scheme 53. Synthesis of poly(ethylene glycol) rosin esters.

Block copolymer of dehydroabietyl ethyl methacrylate and ethylene glycol with disulfide group can be prepared via ATRP according to Scheme 54, prior to neutralization, evaporation and precipitation [168]. Potential applications include drug-delivery nanocarriers for cancer therapy [168].

Poly(ethylene glycol) with (bromoisobutyryl)ethyl disulfide group o

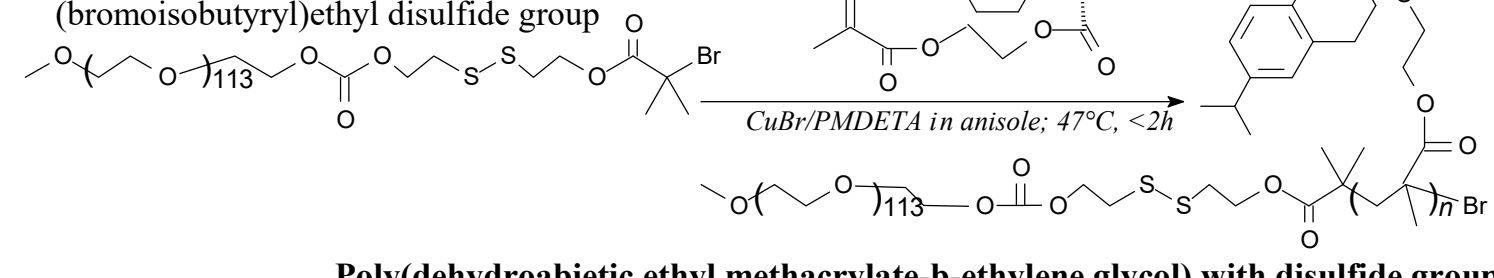

Poly(dehydroabietic ethyl methacrylate-b-ethylene glycol) with disulfide group $\left(\right.$ PEG $_{113}$-Ss-PMrosin 27$)$

Scheme 54. Preparation of block copolymer of dehydroabietyl ethyl methacrylate and ethylene glycol with disulfide group. 
The rosin derivative quaternized poly-(N,N-dimethylaminoethyl methacrylate) can be prepared via "living" reversible addition-fragmentation chain-transfer polymerization (RAFT) from dehydroabietic acid, 3-chloropropanol, N,N-dimethylaminoethyl methacrylate and cumyl dithiobenzoate as a RAFT transfer agent, according to Scheme 55, and using gel chromatography, precipitation and vacuum drying as separation techniques [242]. It can be used as amphipathic antibacterial agent in a wide variety of biomedical and general use applications [242].

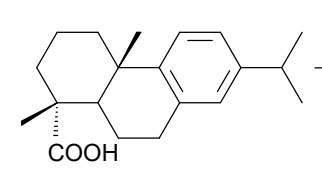

Dehydroabietic acid

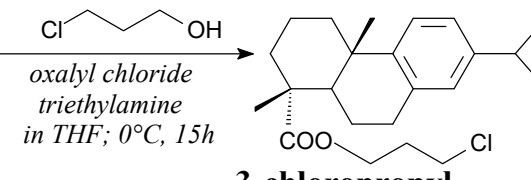

3-chloropropyl

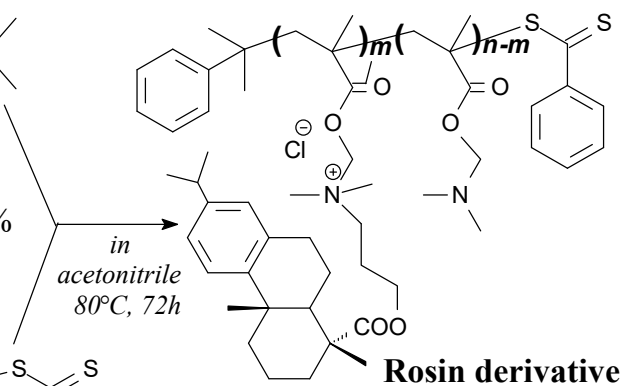

quaternized

poly-DMAEMA

$\mathrm{M}_{\mathrm{n}}=8300,14400,17600$,

$19300,19600,59800$

$N, N$-dimethylaminoethyl methacrylate (DMAEMA)

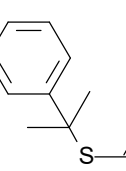

dehydroabietate yield: $65 \%$

$A I B N$
$60^{\circ} \mathrm{C}, 5 h$

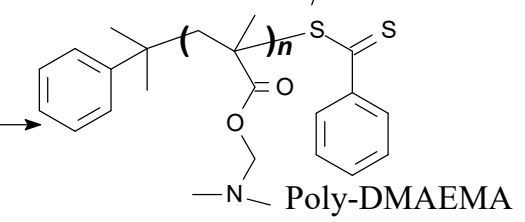

$M_{n}=5490,7500,1400$ or 41000

Scheme 55. Preparation of the rosin derivative quaternized poly(dimethylaminoethyl methacrylate).

\subsubsection{Elastomers}

Poly(dehydroabietic ethyl methacrylate- $\beta$ - $n$-butyl acrylate- $\beta$-dehydroabietic ethyl meth-acrylate) triblock copolymer can be prepared in ATRP polymerization from butyl acrylate, dehydroabietic hydroxyethyl acrylate and diethyl meso-2,5-dibromoadipate according to Scheme 56, prior to diluting, neutralization, evaporation, precipitation and vacuum drying [146]. Its application is sustainable thermoplastic elastomers [146].

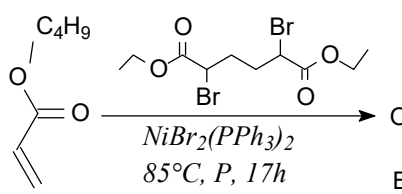

Butyl acrylate
Poly(n-butyl acrylate) macroinitiatior $>0$ yield: $58 \%$

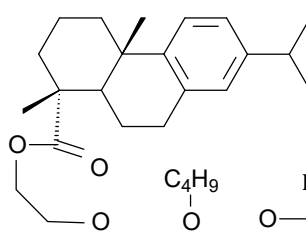

Poly(dehydroabietic ethyl methacrylate- $b$ -n-butyl acrylate- $b$ -dehydroabietic ethyl methacrylate) yield: $36 \%$

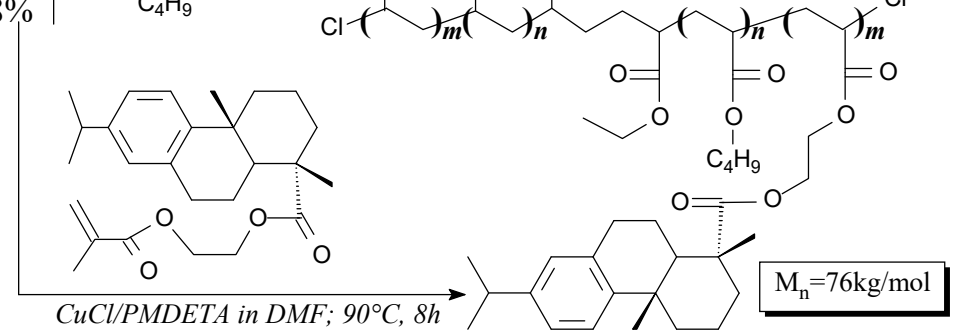

Scheme 56. Synthesis of rosin-based triblock copolymer.

Cellulose/rosin ATRP macroinitiators can be prepared from dehydroabietic acid, cellulose and 2-bromoisobutyryl bromide, according to Scheme 57, prior to drying at $40{ }^{\circ} \mathrm{C}$ [142]. It is used for the preparation of graft copolymers [142]. 


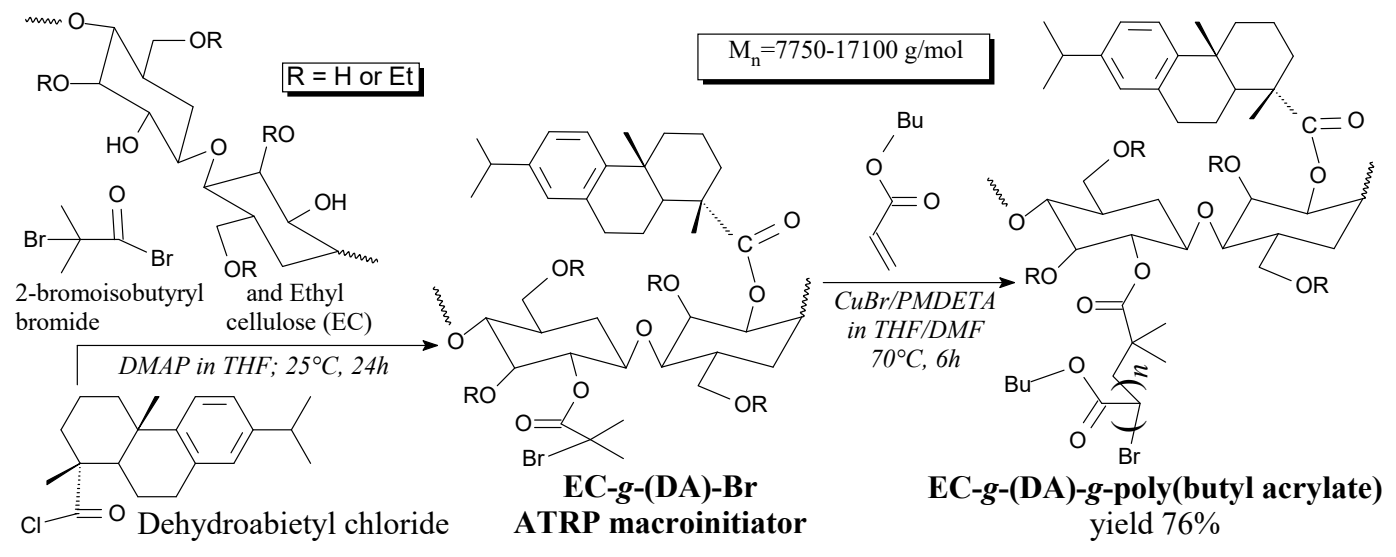

Scheme 57. Synthesis of graft copolymer of rosin-modified ethyl cellulose and butyl acrylate.

Rosin-acid-modified ethyl cellulose/butyl acrylate graft copolymer can be prepared in ATRP reaction from dehydroabietic acid, cellulose, 2-bromoisobutyryl bromide and butyl acrylate according to Scheme 57, prior to sorption of $\mathrm{CuBr}_{x}$ and precipitation in methanol. [142]. Potential applications include thermoplastic elastomers and coatings with UV absorption property [142].

Cellulose grafted by copolymer of rosin acid ethyl methacrylate and alkyl (meth)acrylate can be prepared via ATRP, according to Scheme 58, prior to sorption and precipitation in methanol [166]. Potential applications include "green" thermoplastic elastomers having significant hydrophobic, thermal and mechanical features [166].

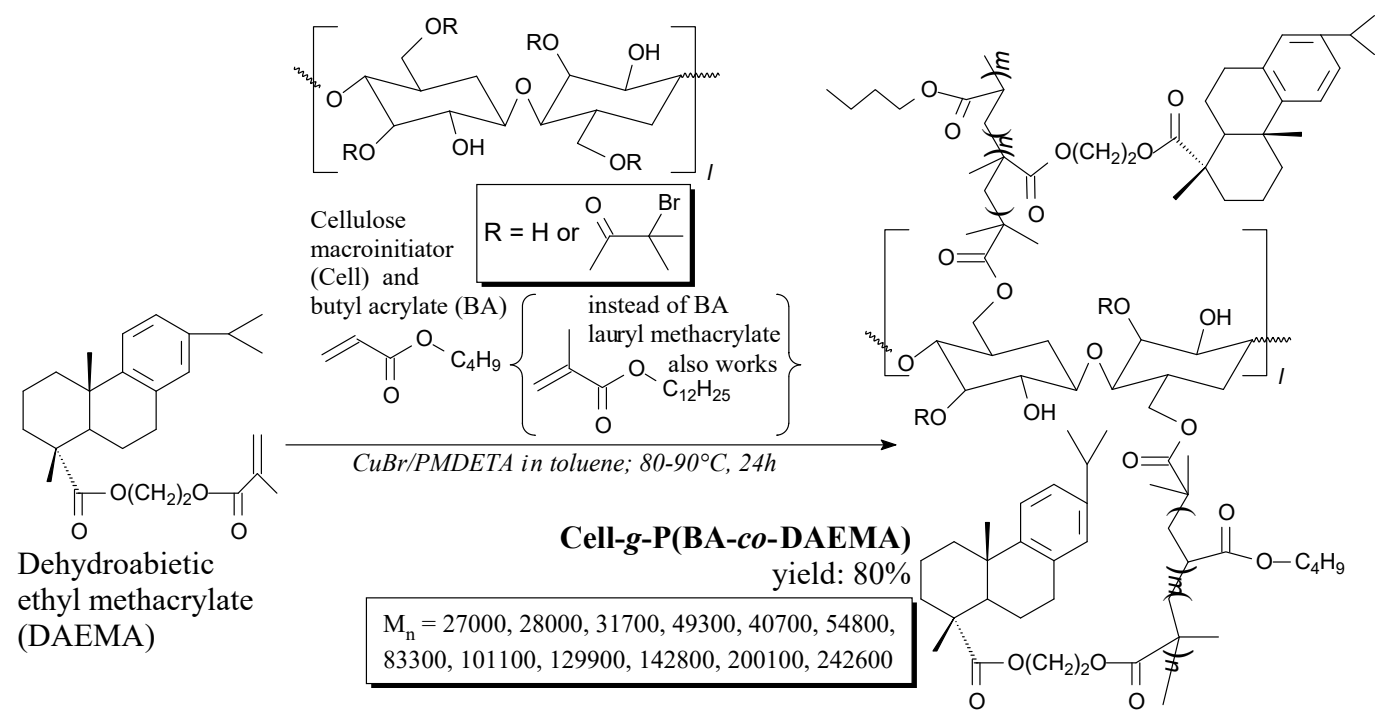

Scheme 58. Synthesis of graft copolymer of cellulose, rosin acid and butyl acrylate (or lauryl methacrylate).

Rosin alcohols are colorless solids, which can be prepared in several ways according to Scheme 59, and using such separation methods like evaporation, extraction, washing and drying $[243,244]$ [245]. They can be used in preparation of cross-linked structures with acrylamide and $N, N^{\prime}$-methylenebisacrylamide [243,244], as well as norbornene-based monomers [245].

Rosin-norbornene monomers, i.e., dehydroabietanyl norborn-5-ene-2-carboxylate and 4-((norborn-5-ene-2-carbonyl)oxy)butyl dehydroabietate, are viscous oily liquids [245]. They can be synthesized from dehydroabietic acid derivatives and norbornenecarboxylic acid according to Scheme 59, prior to evaporation, washing, drying and column chromatography [245]. Its application 
is polymerization, or block copolymerization with norbornene, via "living" ring-opening metathesis polymerization (ROMP) process [245,246].

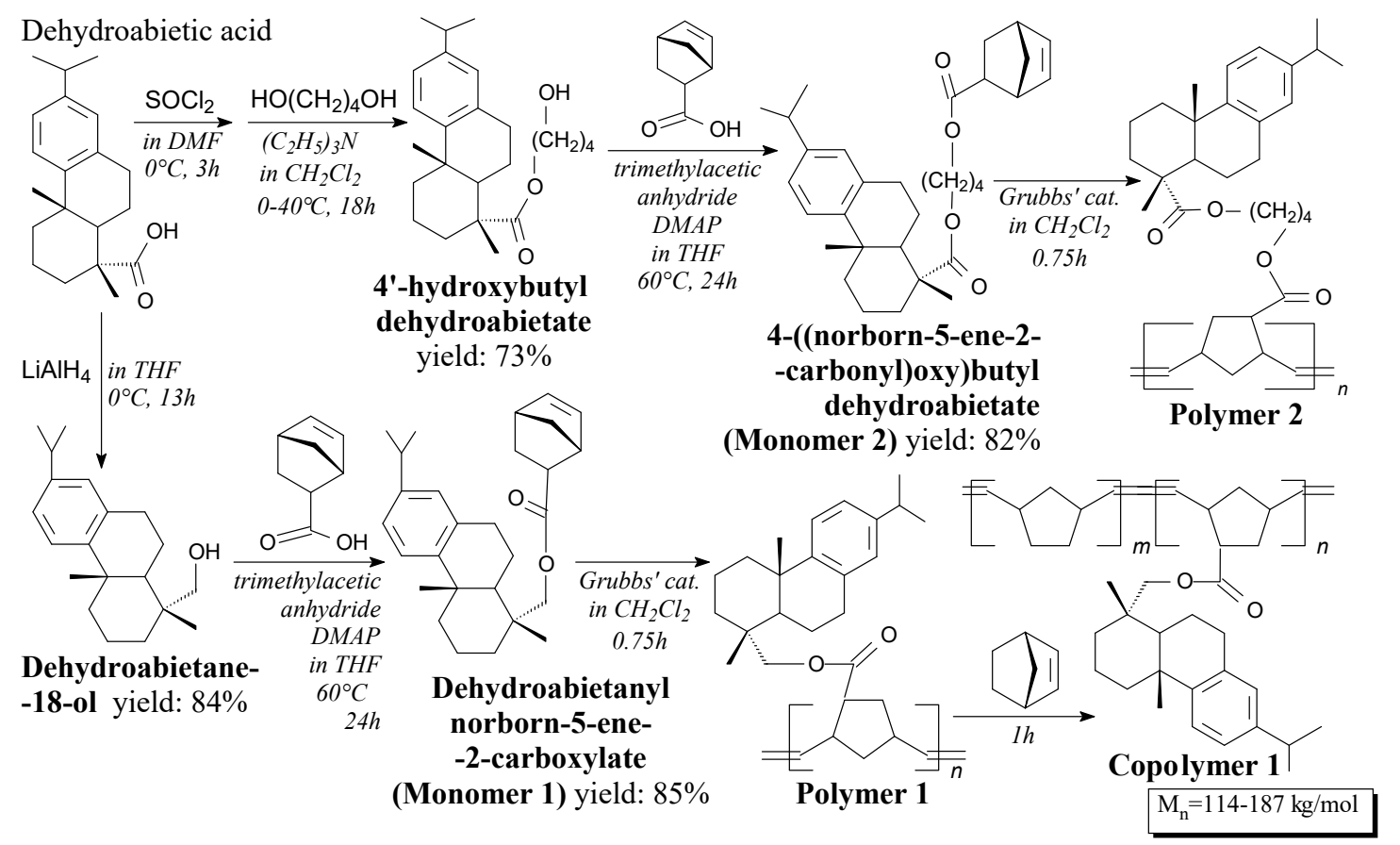

Scheme 59. Synthesis of rosin-norbornene monomers and polymerization of them.

Homopolymers of rosin-modified norbornene can be synthesized via ROMP process according to Scheme 59 [246]. Moreover, triblock and pentablock copolymers with norbornene segments can be prepared [246]. They can be applied as bio-based thermoplastic elastomers showing well-designed architecture and high elastic recovery $[245,246]$.

Rosin-based waterborne polyurethanes can be prepared from maleopimaric acid, diethylene glycol, polyether glycol, toluene diisocyanate, dimethylol propionic acid and trimethylamine according to Scheme 60, and using such separation methods as vacuum drying and rotary evaporation [111]. Such polymers can be also synthesized using fumaropimaric rosin instead of maleopimaric acid [109]. These materials exhibit excellent mechanical properties, thermal stability, water resistance, antimicrobial properties against Gram-negative Escherichia coli and Gram-positive Staphylococcus aureus [109,111] and an affinity for cellulose nanocrystals [112], which allows to apply them in various biomass-based polymer and composite materials.

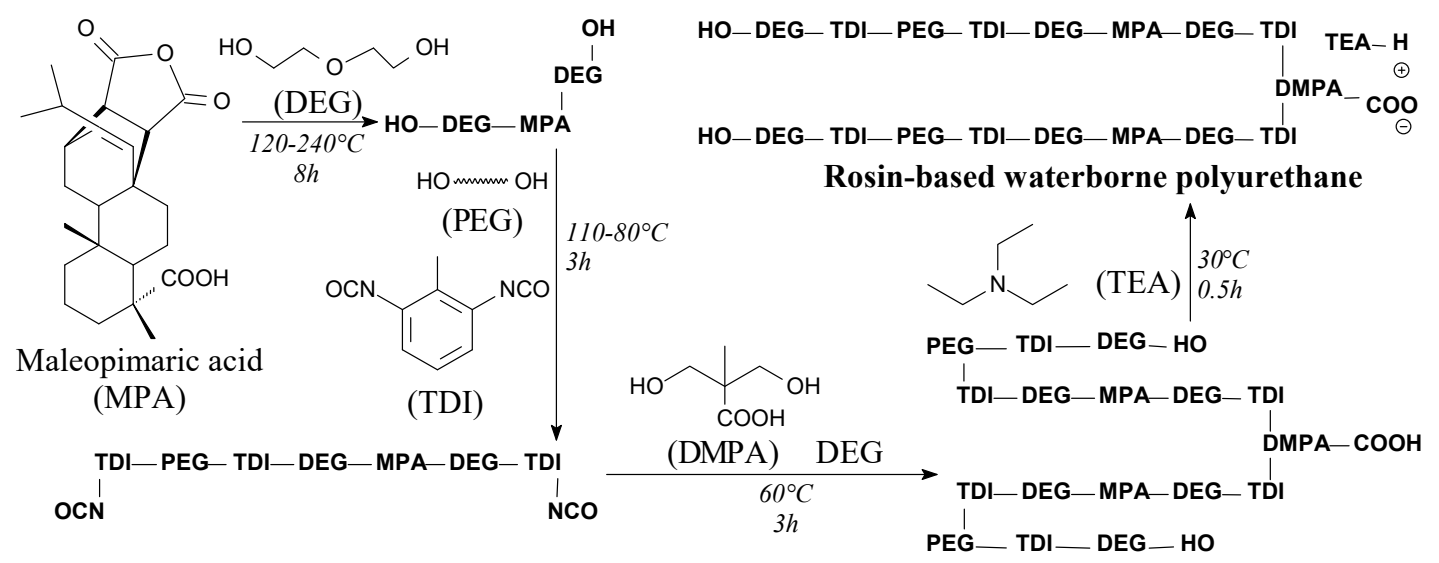

Scheme 60. Preparation of rosin-based waterborne polyurethane. 


\subsubsection{Coatings and Adhesives}

Rosin-modified poly(acrylic acid) is a solid. It can be prepared from poly(acrylic acid) and abietic acid according to Scheme 61, prior to washing and vacuum drying [247]. It can be applied as an excellent binder for silicon-graphite negative electrodes in lithium-ion batteries [247].

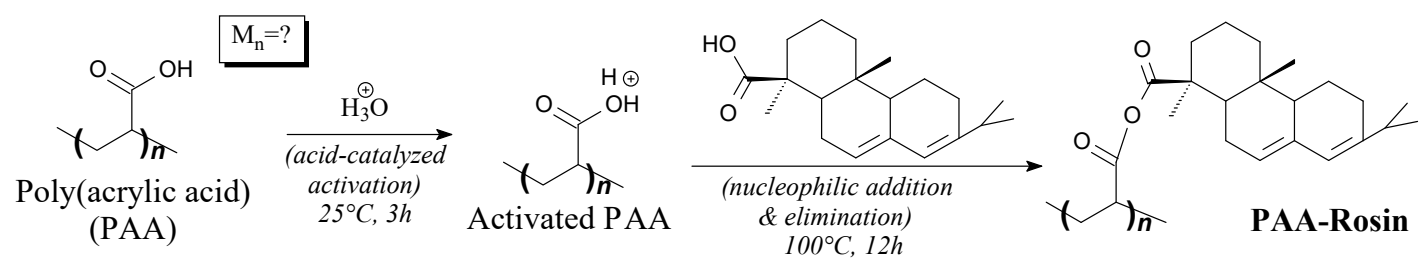

Scheme 61. Preparation of rosin-modified poly(acrylic acid).

$\mathrm{N}$-dehydroabietic acrylamide is a white solid. It can be synthesized from dehydroabietylamine and acryloyl chloride according to Scheme 62, prior to washing and vacuum distillation. It can be used as a bio-based acrylic monomer in compolymerization processes instead of rigid petroleum-based monomers [161].

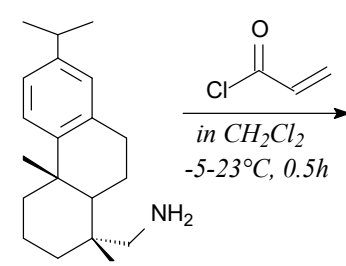

Dehydroabietylamine

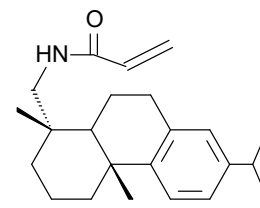

N-dehydroabietic acrylamide (DHAAM)

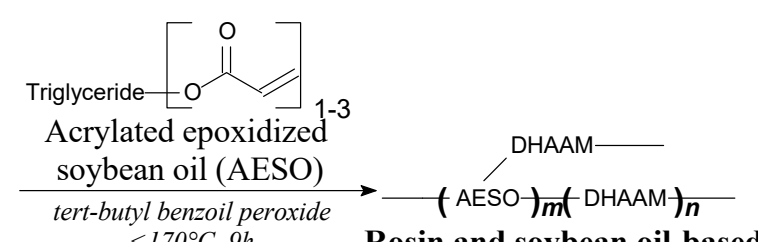

$<170^{\circ} \mathrm{C}, 9 \mathrm{~h}$
Rosin and soybean oil-based acrylic copolymer

Scheme 62. Preparation of rosin and plant oil-based acrylic copolymers.

Rosin and soybean oil-based acrylic copolymers can be prepared from $N$-dehydroabietic acrylamide and acrylated epoxidized soybean oil according to Scheme 62 [161]. They are characterized by considerable hydrophobicity and heat resistivity and also other properties comparable with similar petroleum-based materials [161].

Rosin and POSS-based non-isocyanate polyurethanes can be prepared from rosin-based cyclic carbonate, polyamine and cyclic carbonate-functionalized POSS according to Scheme 63 [200]. Their applications include coatings showing improved water tolerance, hardness and thermal stability [200].

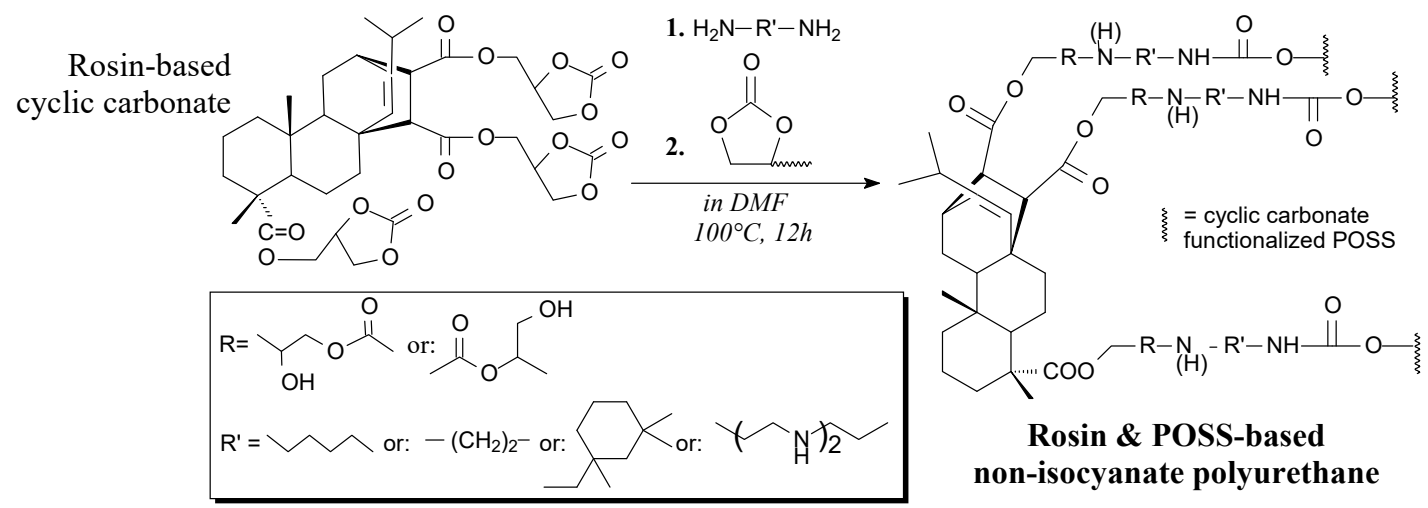

Scheme 63. Preparation of rosin \& POSS-based non-isocyanate polyurethane.

Rosin can be introduced as a chain extender into polyurethanes to obtain rosin-based urethane-amide hard segments, according to Scheme 64 [248]. A potential application of the prepared 
materials is as sealants for non-invasive disc regeneration surgery [248]. Physical mixtures of rosin and 1,4-butanediol were also investigated for this use [249].

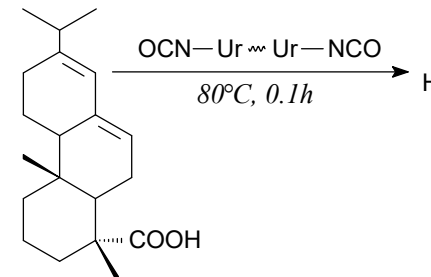

Rosin

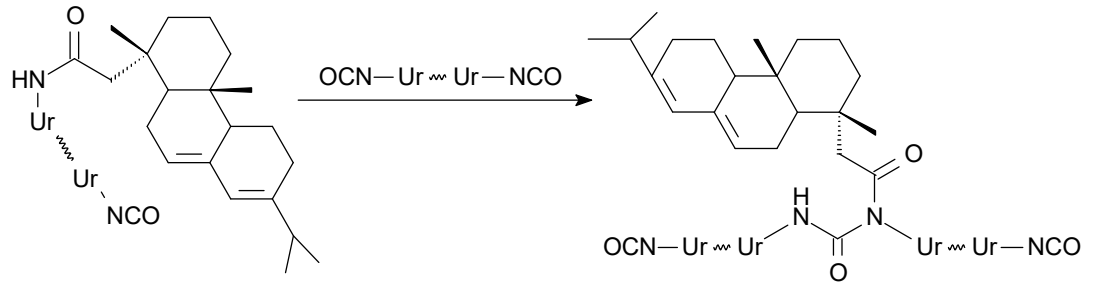

Urethane-amide hard segment

Scheme 64. Preparation of rosin-modified urethane-amide hard segments.

Maleopimaric acid-modified polyester polyol aqueous dispersion can be prepared from maleopimaric acid, adipic acid, isophtalic acid, 5-sulfoisophtalic acid, neopentyl glycol and trimethylolpropane, according to Scheme 65, prior to dissolving/dispersing in water and diethylene glycol monoethyl ether acetate as a cosolvent [91]. It can be applied in two-component waterborne polyurethane materials and coatings [110] showing improved thermal stability, hardness and resistances to ethanol and water [91,110].

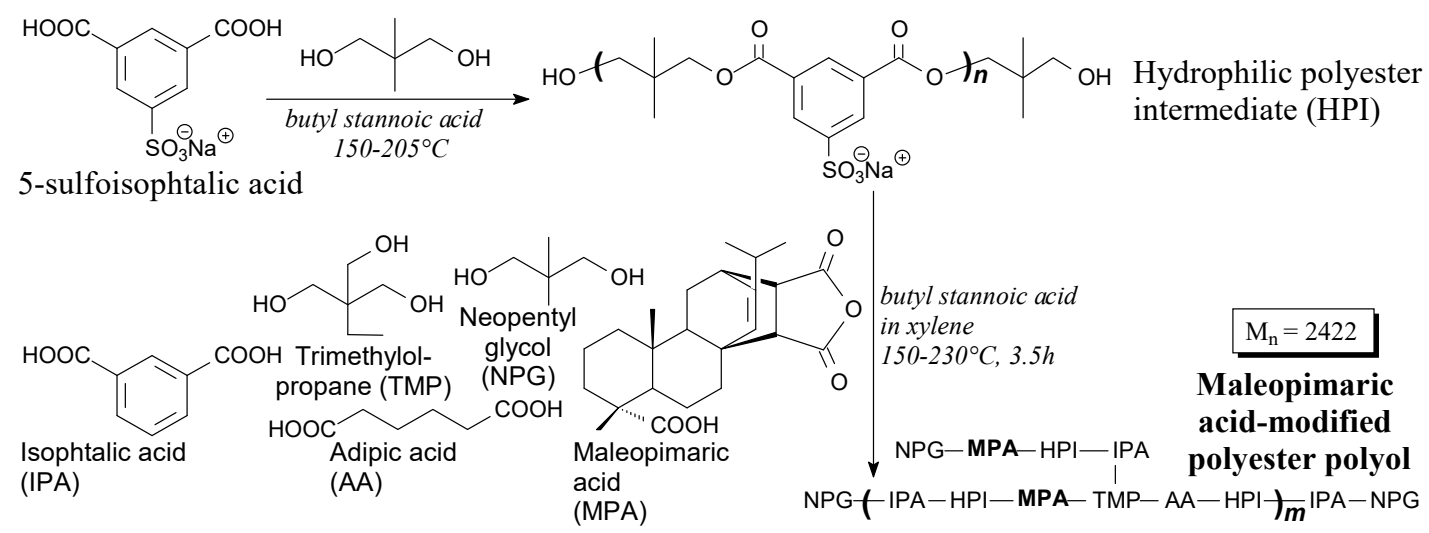

Scheme 65. Preparation of hydrophilic maleopimaric acid-modified poliester polyol.

\subsubsection{Surfactants}

Rosin-based comb-like polymeric surfactants can be prepared from rosin glycidyl methacrylate and methacrylate polyethylene glycol ester according to Scheme 66, prior to vacuum drying, precipitation, dialysis and freezing [175]. Their application include preparation of pymetrozine water suspension concentrates [175].

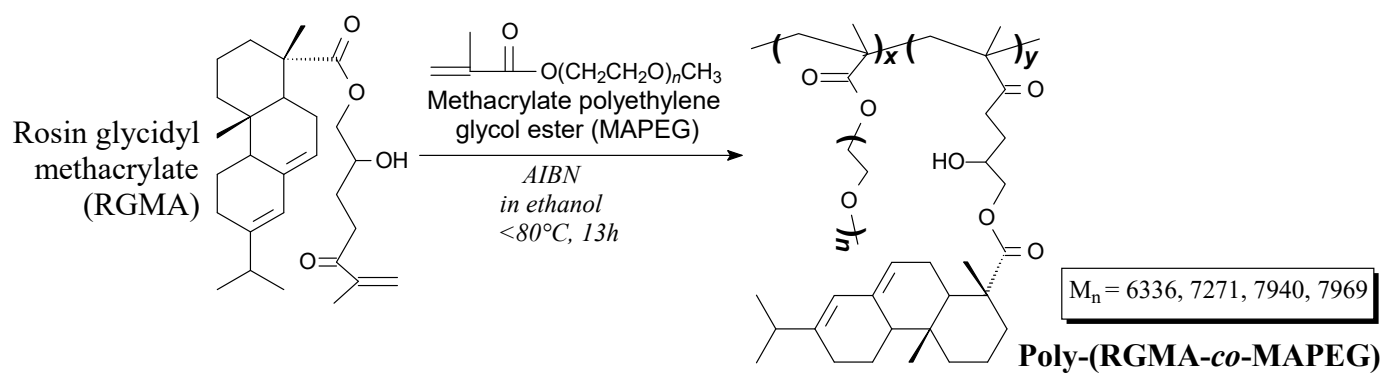

Scheme 66. Preparation of comb-like surfactants.

Polyesters of acrylated rosin and polyethylene glycols can be prepared according to Scheme 67 [125]. They can be used as surfactants in preparation of stable emulsions [125]. 


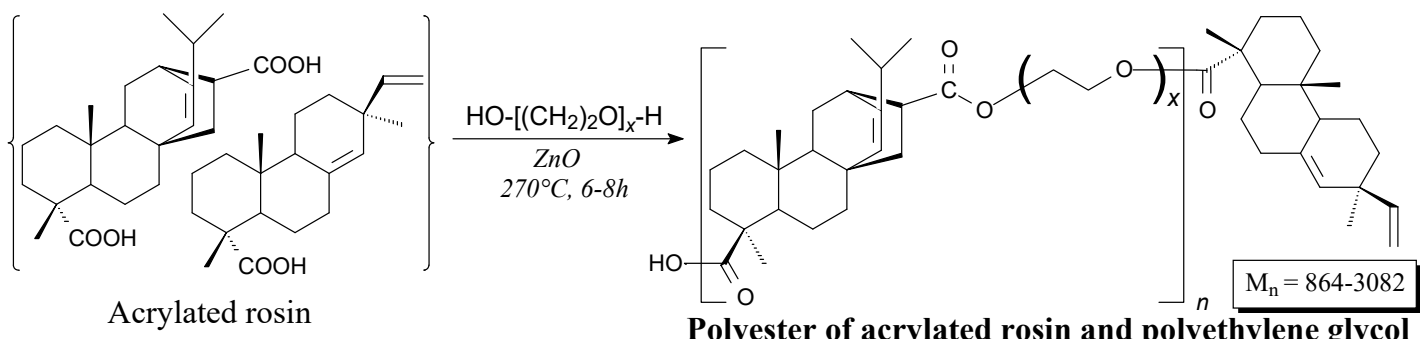

Scheme 67. Preparation of acrylated rosin/polyethylene glycol polyester.

Rosin imide polyethers are light brown solids. They can be prepared from rosin, poly(ethylene glycol) and polyamines according to Scheme 68, and using such separation methods as washing, drying, precipitation and filtration $[250,251]$. They can be applied as petroleum crude oil sludge dispersants [250].

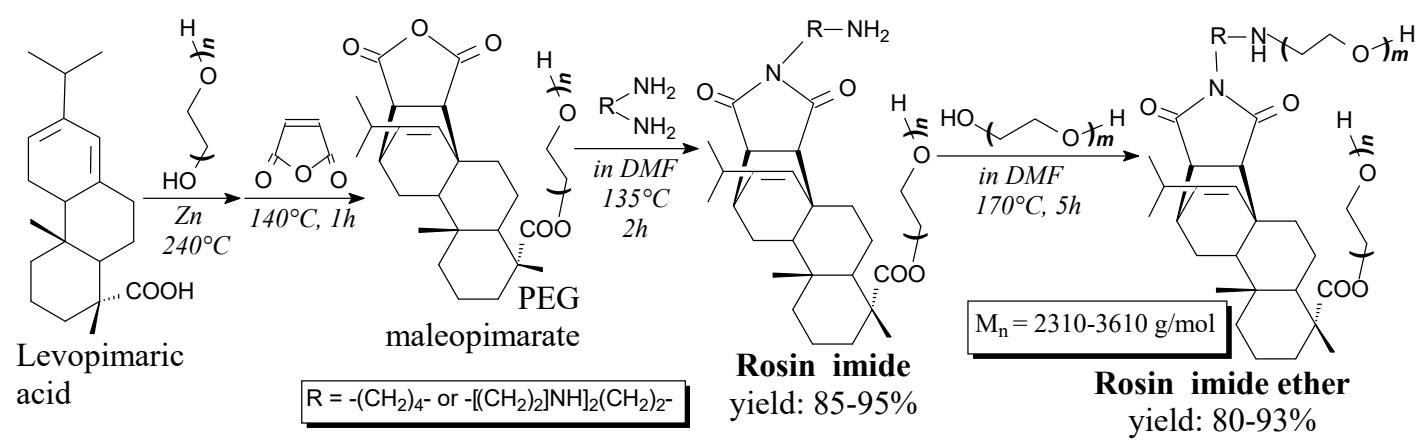

Scheme 68. Preparation of non-ionic rosin imide polyethers.

\subsubsection{Sorbents}

Rosin-poly(acrylamide) star copolymers can be prepared according to Scheme 69, prior to Soxhlet extraction using acetone and drying [243,244,252]. They can be used for wastewater treatment $[243,244,252]$ and as a matrix for $\mathrm{Fe}_{3} \mathrm{O}_{4}$ nanoparticles [253].

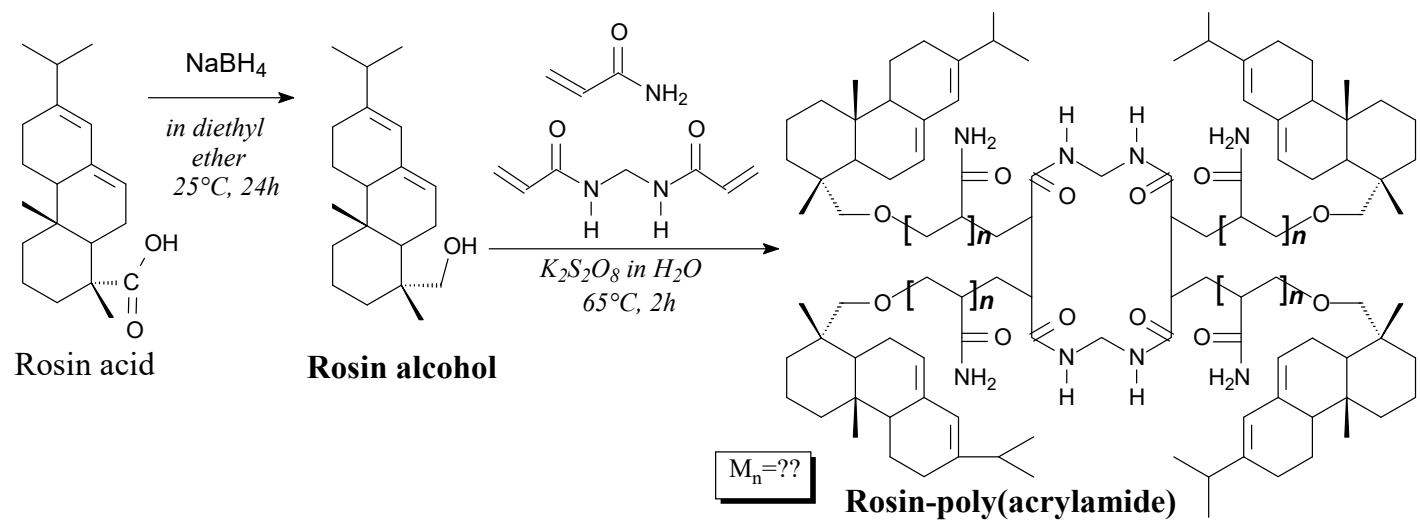

Scheme 69. Synthesis of rosin alcohol and rosin-poly(acrylamide) star copolymer.

Linear rosin-modified cationic poly(acrylamide) can be prepared from dehydroabietyl chloride, bromopropan-1-ol, methyldiallylamine, acrylamide and diallyl dimethyl ammonium chloride in a few-step process, according to Scheme 70, followed by operations such as filtration, washing, drying and recrystallization [149]. Its utilization may be in flocculation processes [149]. 


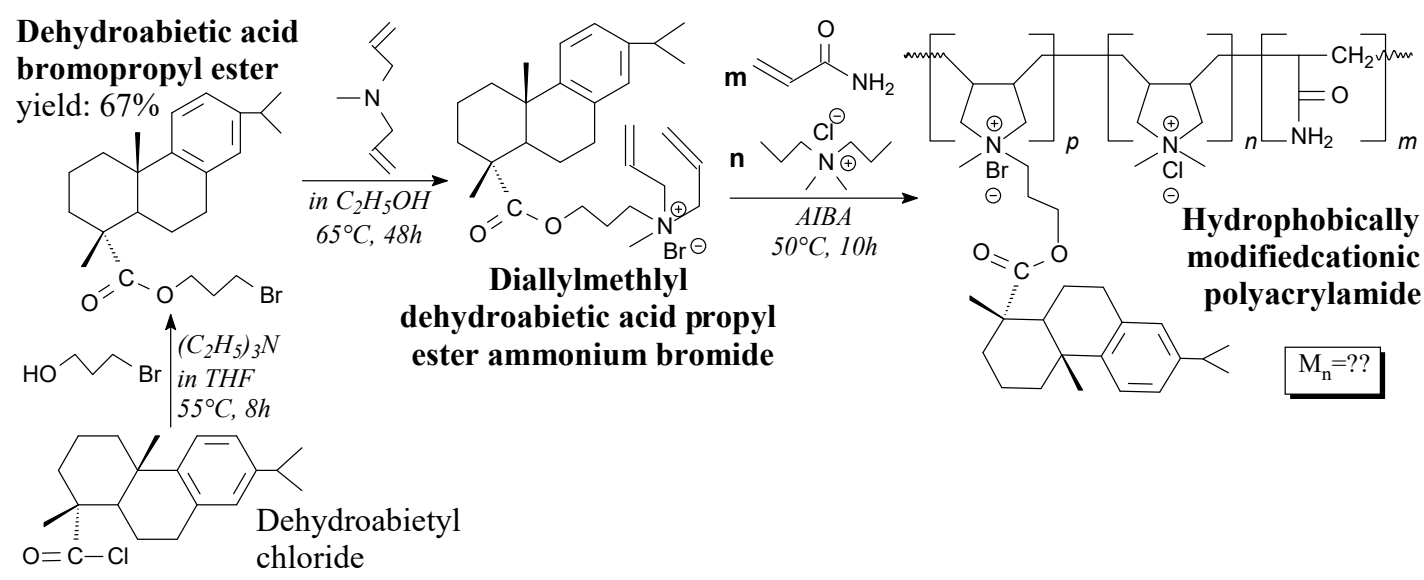

Scheme 70. Preparation of linear rosin-poly(acrylamide) copolymer.

Rosin tetraethylenepentamine amide is a solid. It can be prepared from maleopimaric acid and tetraethylenepentamine according to Scheme 71, prior to precipitation, washing and lyophilization [115]. It creates nano-micelles in aqueous solutions and can act as a sorbent and sinking agent in metal ions removal [115].

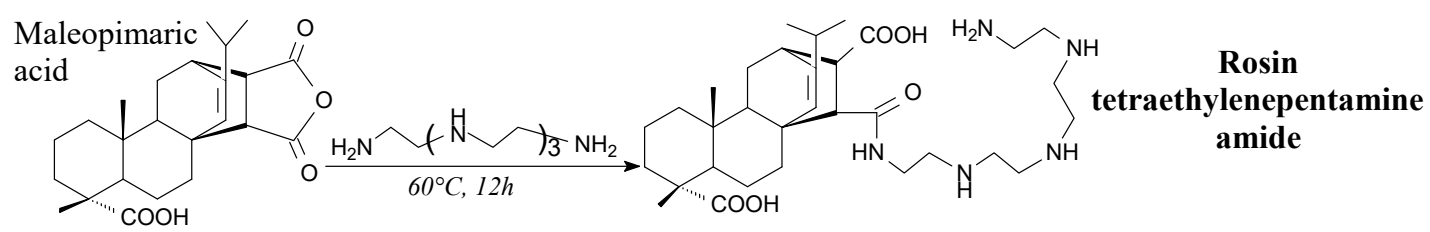

Scheme 71. Preparation of rosin-tetraethylenepentamine amide.

\subsubsection{Organosilicons}

Rosin glycidyl ester is a brown, viscous liquid. It can be synthesized from rosin and epichlorohydrin according to Scheme 72 without further purification [254]. It can be used for preparation of cross-linking agent for silicone rubber [254].

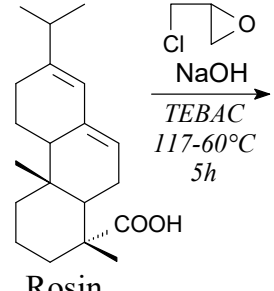

Rosin<smiles>CC(C)C1=CC2=CCC3C(C)(C(C)C)CCCC3(C)C2CC1</smiles><smiles>CCC1CO1</smiles>

Rosin glycidyl ester yield: $92 \%$

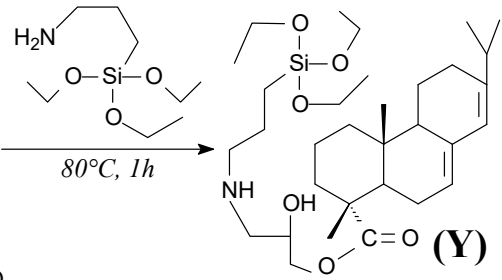

Rosin-modified aminopropyltrietoxysilane yield: $100 \%$

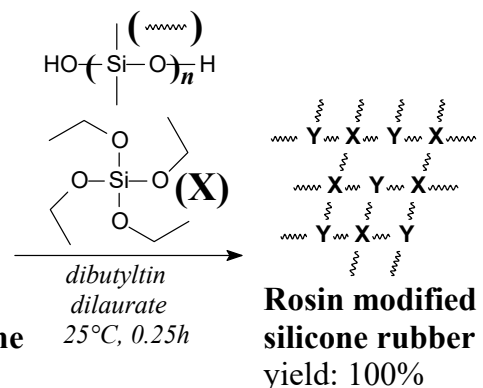

yield: $100 \%$

Scheme 72. Preparation of rosin-modified room-temperature-vulcanized silicone rubber.

Rosin-modified room-temperature-vulcanized silicone rubber can be prepared from rosin glycidyl ester, aminopropyltrietoxysilane, tetraetoxysilane and hydroxyl-terminated polydimetoxysilane according to Scheme 72 [254]. Rosin-modified silicones shows significantly better thermal and mechanical properties in comparison with unmodified silicone [254-256].

Maleated rosin-modified vinyl fluorosilicone resin can be prepared from maleopimaric acid and siloxanes according to Scheme 73 prior to vacuum evaporation [116]. It can be used in preparation of fluorosilicone rubber, having improved mechanical and thermal properties in comparison with unmodified sample [116]. 


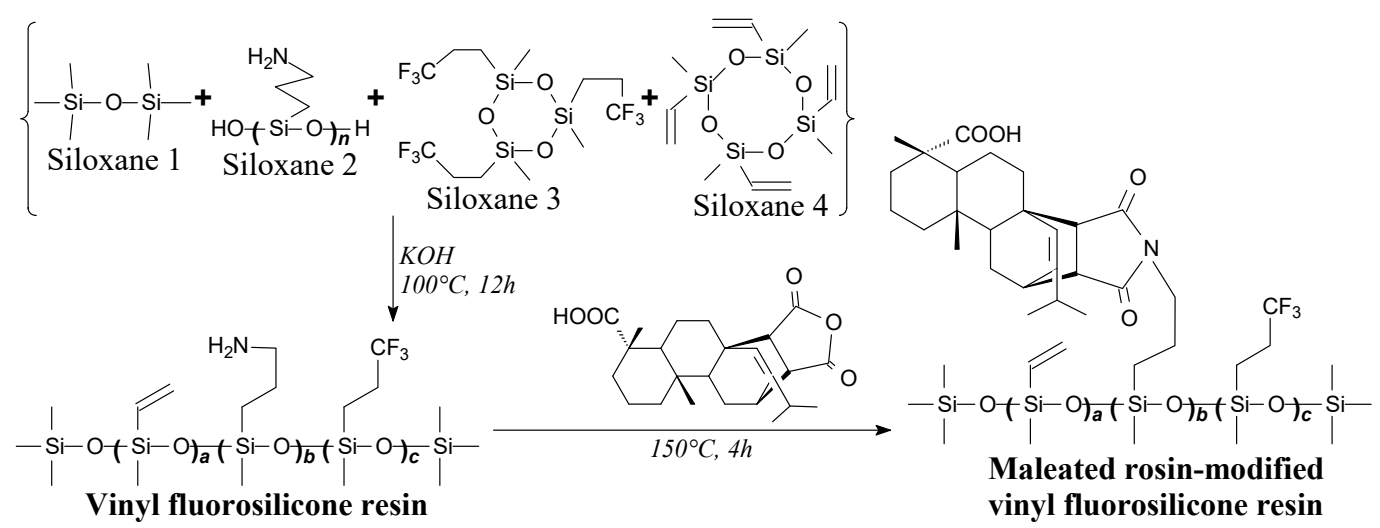

Scheme 73. Preparation of maleated rosin-modified vinyl fluorosilicone resin.

\subsubsection{Polysaccharides}

Superhydrophobic wood can be prepared using maleated rosin, aluminum chloride and tetrabutyltitanate according to Scheme 74 [119]. Such a hydrophobic material is appreciated in construction. Related starch-rosin materials have been also prepared [120].

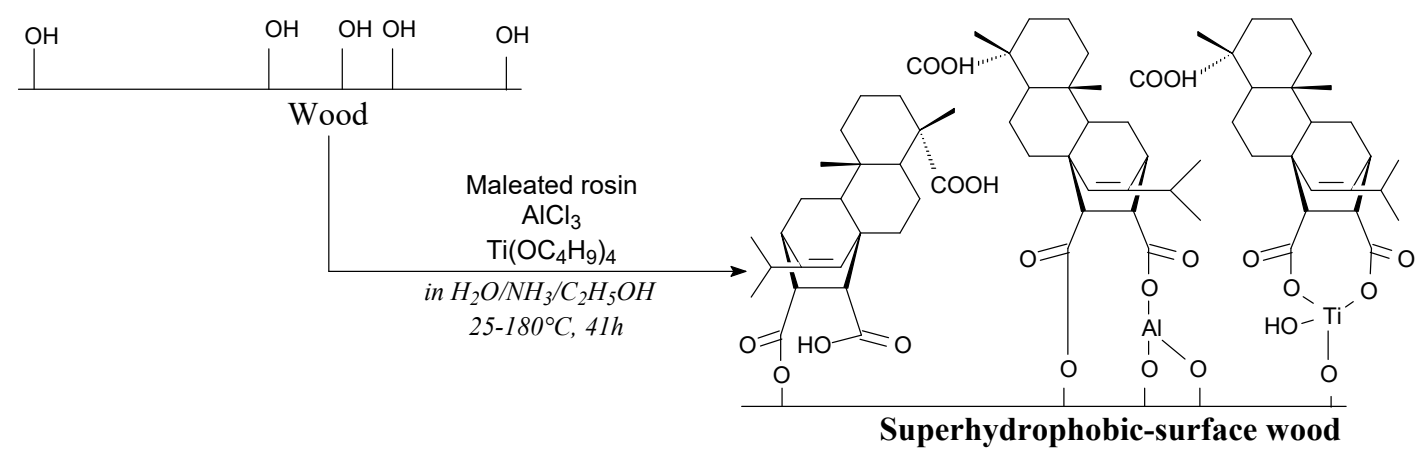

Scheme 74. Preparation of rosin-impregnated superhydrophobic wood.

Rosin-esterified starch biopolymer can be prepared according to Scheme 75, prior to filtration, precipitation, washing and drying $[257,258]$. Rosin decreases solubility and swelling of starch, which potentially allows to use this polymer in food and biomedical materials [257].

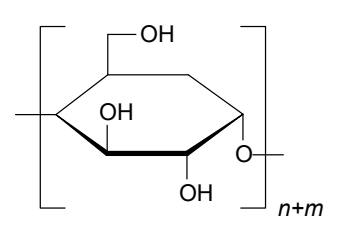

Starch

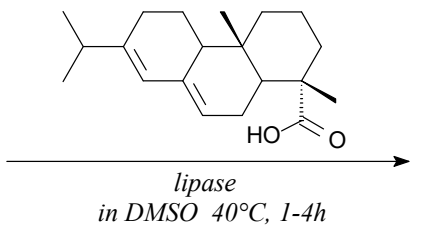

Degree of substitution:

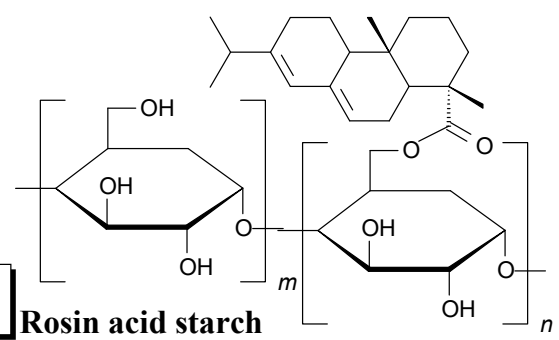

Rosin acid starch

Scheme 75. Preparation of rosin-esterified starch.

Cellulose nanofibers and nanocrystals surface-modified by rosin can be prepared according to Scheme 76 , prior to washing in ethanol $[259,260]$. They can be used as antibacterial reinforcements in bio-based package films [260]. In similar way hemp fibers can be modified by tall oil rosin acids in order to improve the reinforcement adhesion to an epoxy matrix [261]. 


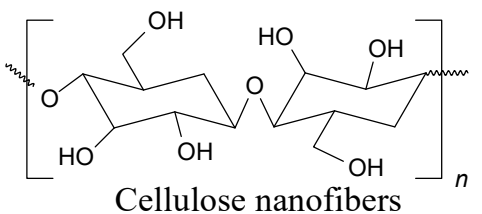

Cellulose nanofibers

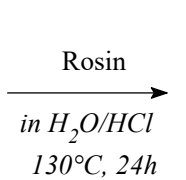

$130^{\circ} \mathrm{C}, 24 \mathrm{~h}$

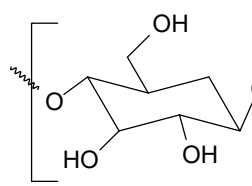

Rosin modified cellulose nanofibers

Scheme 76. Preparation of rosin-modified cellulose nanofibers.

Chitosan grafted by rosin acrylate is a solid. It can be prepared from chitosan and rosin acid hydroxyethyl acrylate according to Scheme 77 prior to precipitation, filtration, washing and drying [172]. It can be potentially used in controlled release applications [172].

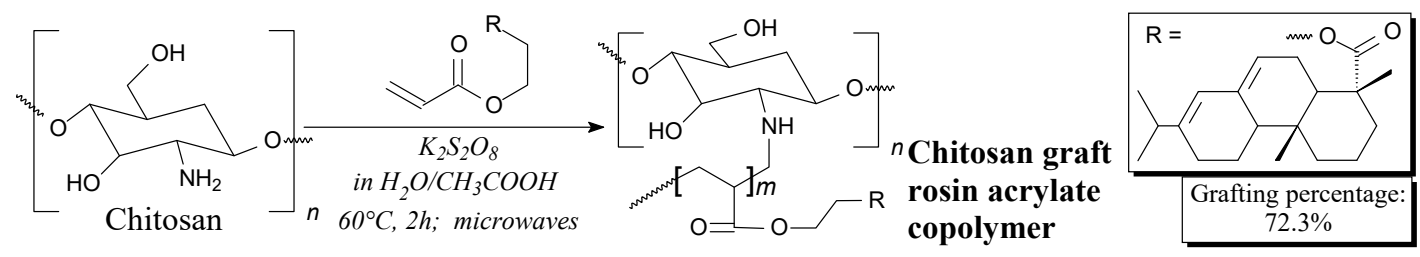

Scheme 77. Preparation of chitosan graft rosin acrylate copolymer.

\subsubsection{Other Materials}

Dehydroabietic acid-glycerol carbonate product can be prepared from dehydroabietic acid and glycerin carbonates according to Scheme 78 [262]. It can be applied in xerographic tonners [262].

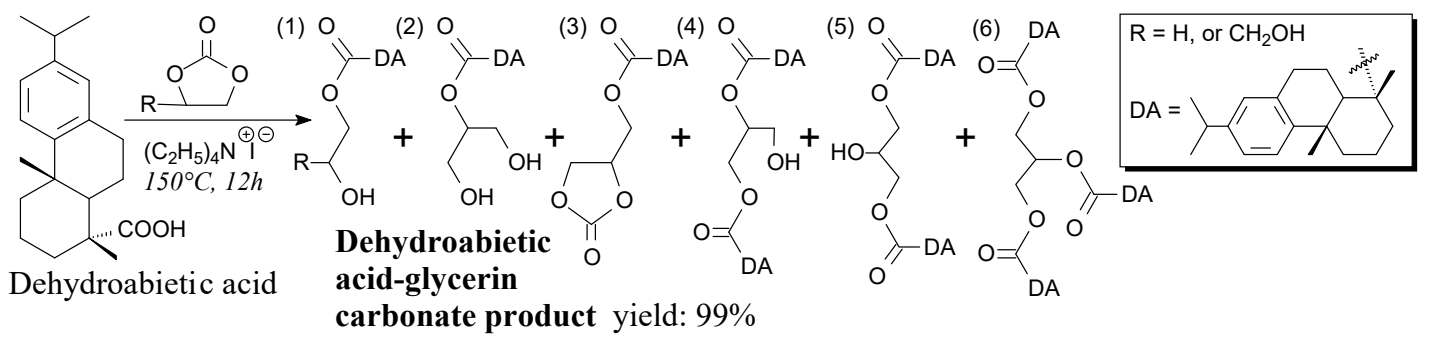

Scheme 78. Preparation of rosin-glycerin carbonate xerographic toner.

Rosin-polyphthalate resin is a glossy light yellow solid. It can be prepared from maleopimaric acid, and phthalic anhydride-glycerol polyester according to Scheme 79 prior to vacuum drying [117]. Its application is an environmentally-friendly phenol-free printing ink [117].

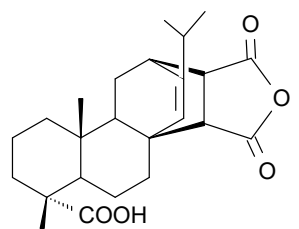

Maleopimaric acid
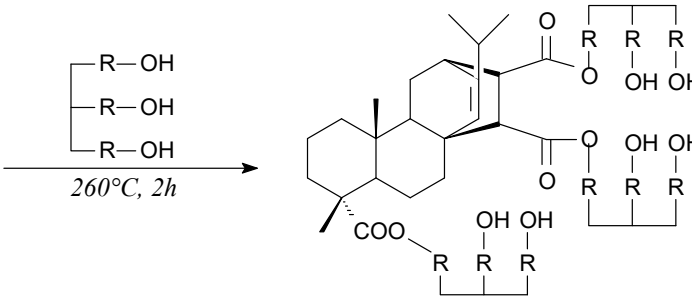

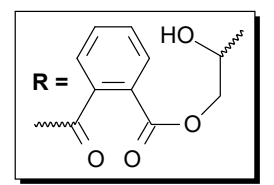

Rosin-based phenol-free resin

Scheme 79. Preparation of rosin-based phenol-free resin.

Rosin propargyl ester is a white, transparent liquid. It can be synthesized from rosin chloride and propargyl alcohol according to Scheme 80, prior to washing and column chromatography [147]. It can be used to prepare caprolactone graft copolymers [147].

Rosin ester containing poly ( $\alpha$-azide- $\varepsilon$-caprolactone) can be prepared from rosin propargyl ester, $\alpha$-chloro- $\varepsilon$-caprolactone and sodium azide according to Scheme 80 , and using such separation methods 
as centrifugation and vacuum drying [147]. This biodegradable copolymer shows properties similar to poly(methyl acrylate) [263]. Similar polymers with quaternary ammonium groups showing antimicrobial properties can be also prepared [264].

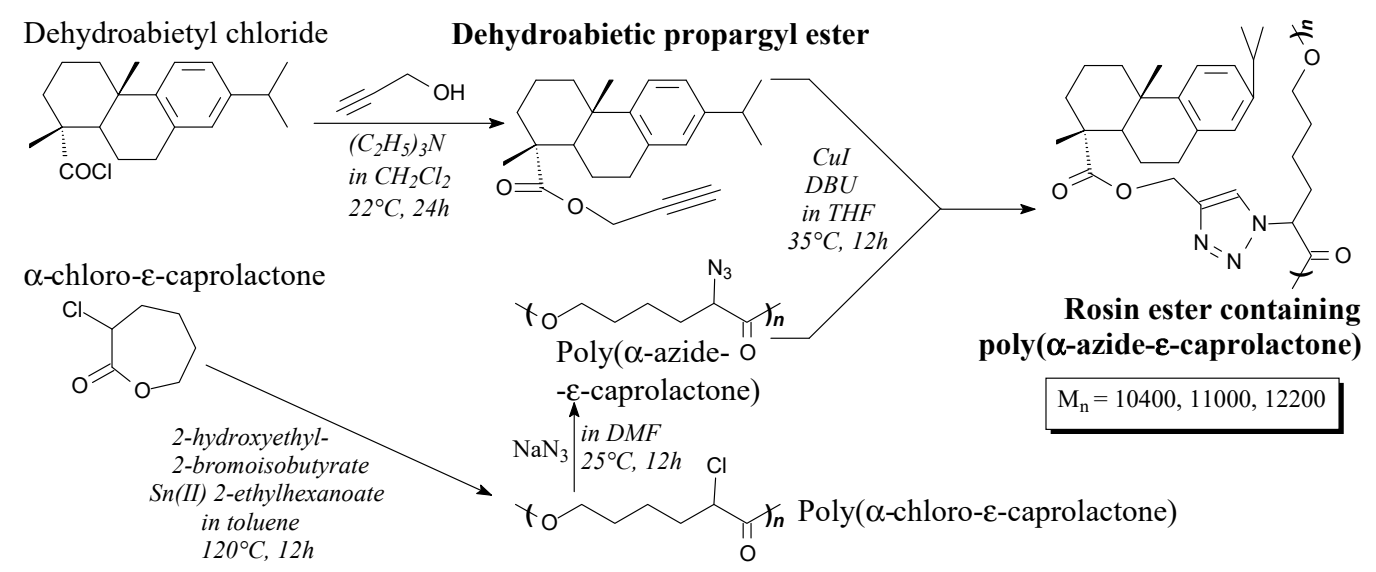

Scheme 80. Preparation of rosin ester containing poly( $\alpha$-azide- $\varepsilon$-caprolactone).

Acrylic rosin methacryl diester can be prepared from acrylic rosin and 2-hydroxyethyl methacrylate according to Scheme 81, prior to rotary evaporation and vacuum drying [124]. It can be used as acrylic monomer or resin [124].

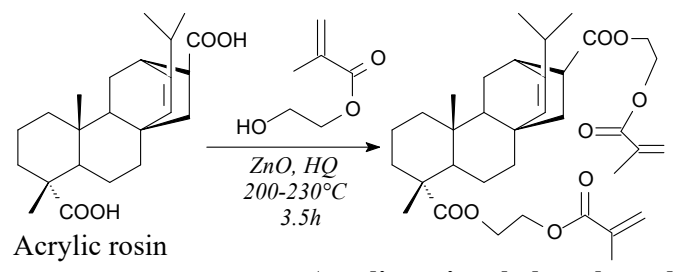

Acrylic rosin ethyl methacryl diester yield: $92 \%$

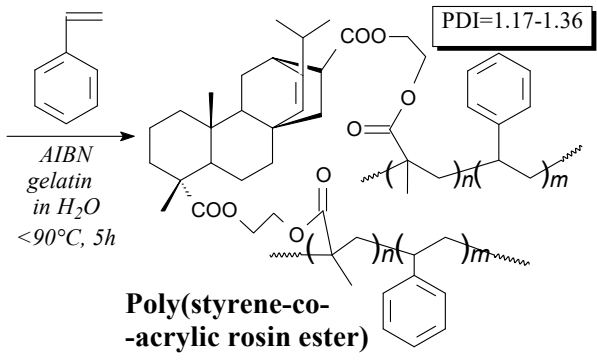

-acrylic rosin ester)

Scheme 81. Preparation of styrene and acrylic rosin ester copolymer.

Poly(styrene-co-acrylic rosin ester) can be prepared via suspension polymerization of acrylic rosin methacryl ester and styrene according to Scheme 81, prior to washing, filtration and vacuum drying [124]. Its application is microspheres [124].

Rosin-tung oil Diels-Alder adduct is a yellowish solid. It can be prepared from levopimaric acid and tung oil according to Scheme 82 , prior to precipitation and drying $[265,266]$. Its application is a filler, tackifier and adhesion promoter in polyurethane [265] and UV-curable adhesives [266].

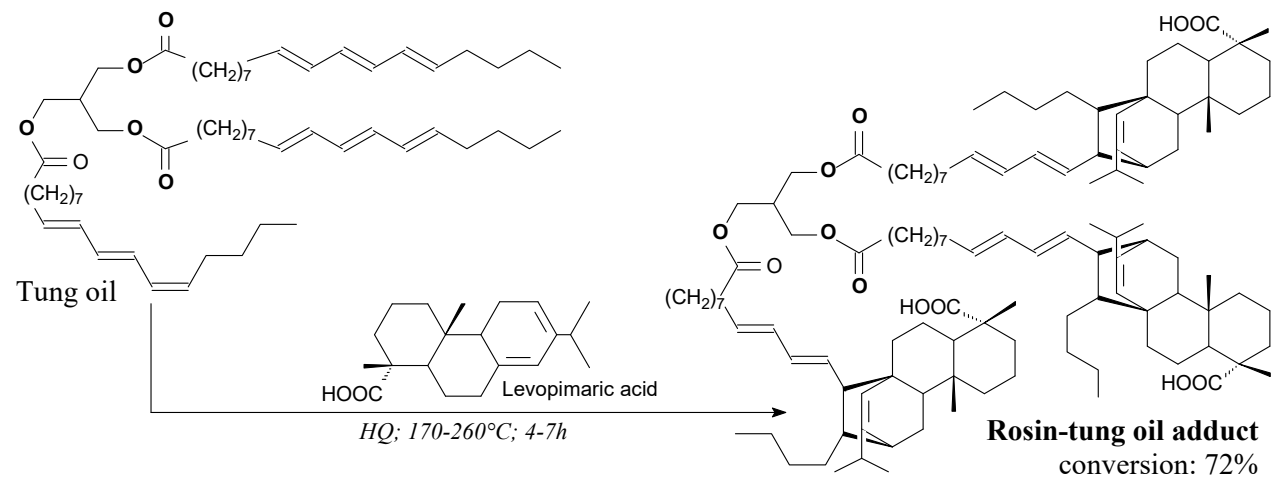

Scheme 82. Preparation of idealized rosin-tung oil Diels-Alder adduct. 
Acrylic-vinyl copolymer with rosin moieties is a slightly yellow solid. It can be prepared from rosin ethyl methacrylate, styrene and divinylbenzene according to Scheme 83, prior to washing, filtration and drying [267]. Its application is polymer microspheres for adsorption and separation [267].

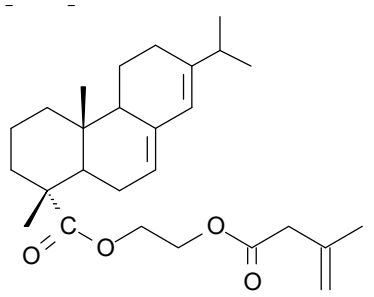

Rosin ethyl methacryalte

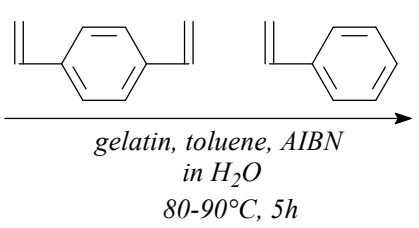

Acrylic-vinyl microspheres with rosin moieties

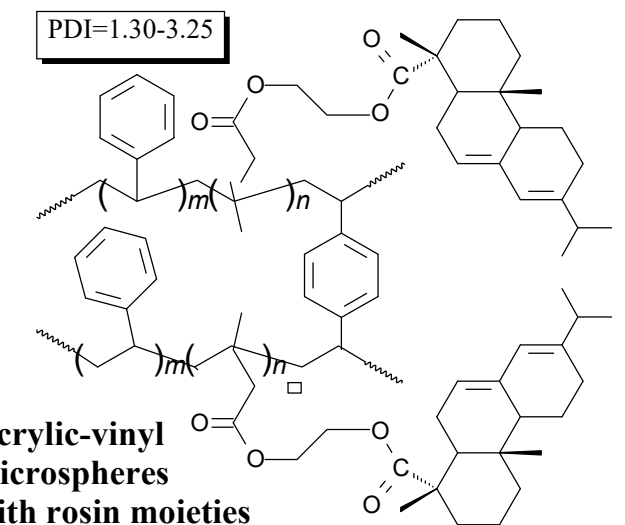

Scheme 83. Preparation of acrylic-vinyl copolymer with rosin moieties.

Rosin/lignin grafted copolymers can be prepared from lignin and dehydroabietic acid derivatives in two ways: simple grafting or ATRP polymerization, according to Scheme 84 and using such separation methods as precipitation, filtration, washing and vacuum drying [169]. These materials are characterized by strongly increased hydrophobicity compared to raw lignin [169].
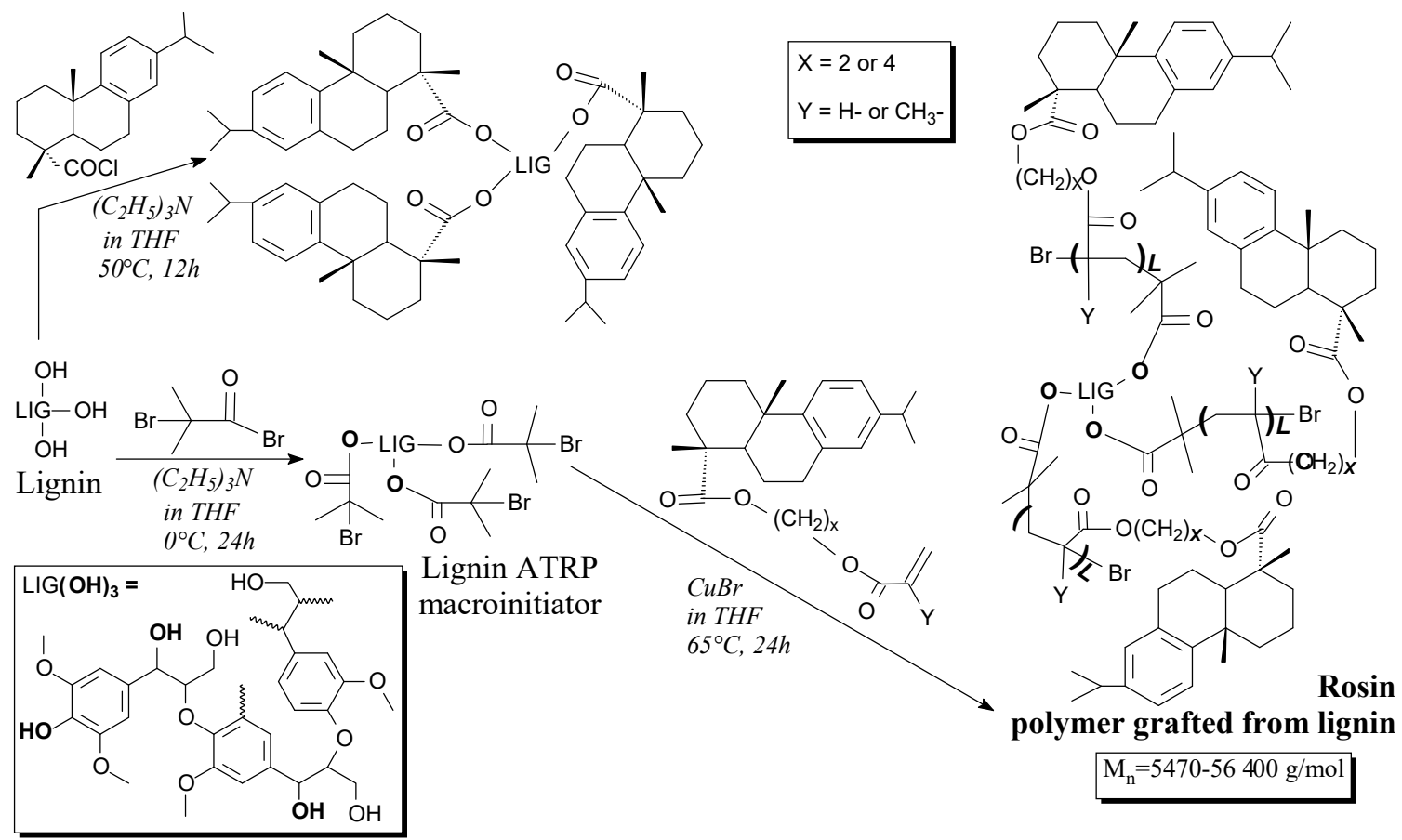

$\mathrm{M}_{\mathrm{n}}=5470-56400 \mathrm{~g} / \mathrm{mol}$

Scheme 84. Preparation of lignin materials hydrophobized by rosin.

Rosin-caprolactone diblock copolymers can be prepared from dehydroabietic ethyl methacrylate, $\varepsilon$-caprolactone and 2-hydroxyethyl 2-bromoisobutyrate according to Scheme 85 prior to precipitation and washing [170]. They can be applied in areas designed for simultaneously bio-based and biodegradable materials [170].

Acrylpimaric acid hydroxyethyl polyesters are light yellow solids. They can be prepared via polycondensation of corresponding acrylpimaric diols according to Scheme 86 prior to grinding, 
washing and drying [138]. Such polymers can be potentially applied in the modern electrical and electronic industries, especially for the environmentally friendly green products [138].

Furthermore, rosin can be pyrolized in order to prepare a matrix for silver nanoparticles to apply as antibacterial filler for wooden furniture or air filter for indoors [268], a catalyst carrier with potential application as counter electrode for dye-sensitized solar cells [269], a coating for bentonite particles and support for $\mathrm{Fe}_{2} \mathrm{O}_{3}$ nanoparticles for chromium ions adsorption [270], and activated carbons [271,272].

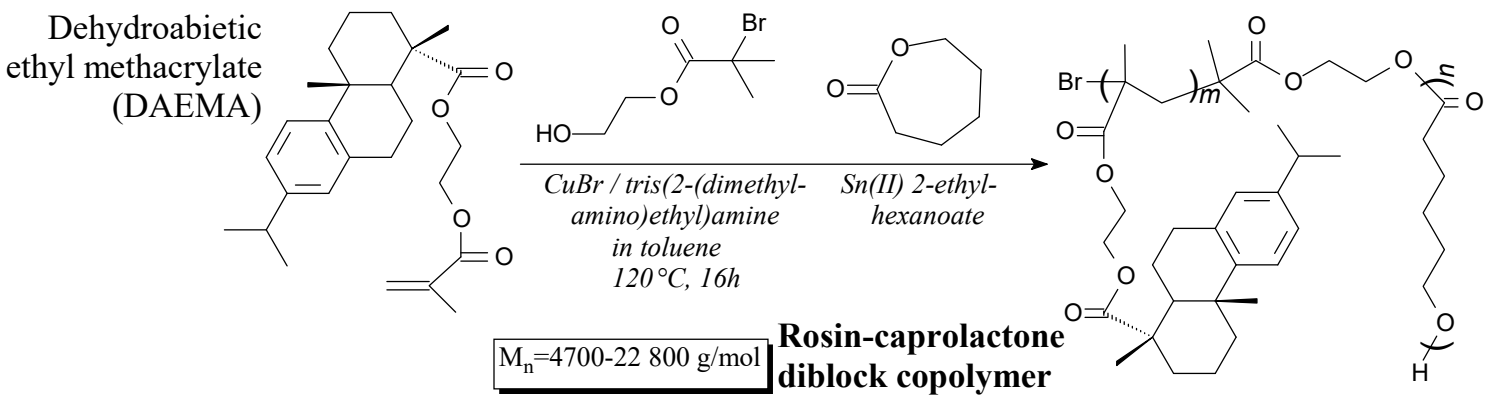

Scheme 85. Preparation of rosin-caprolactone diblock copolymer.

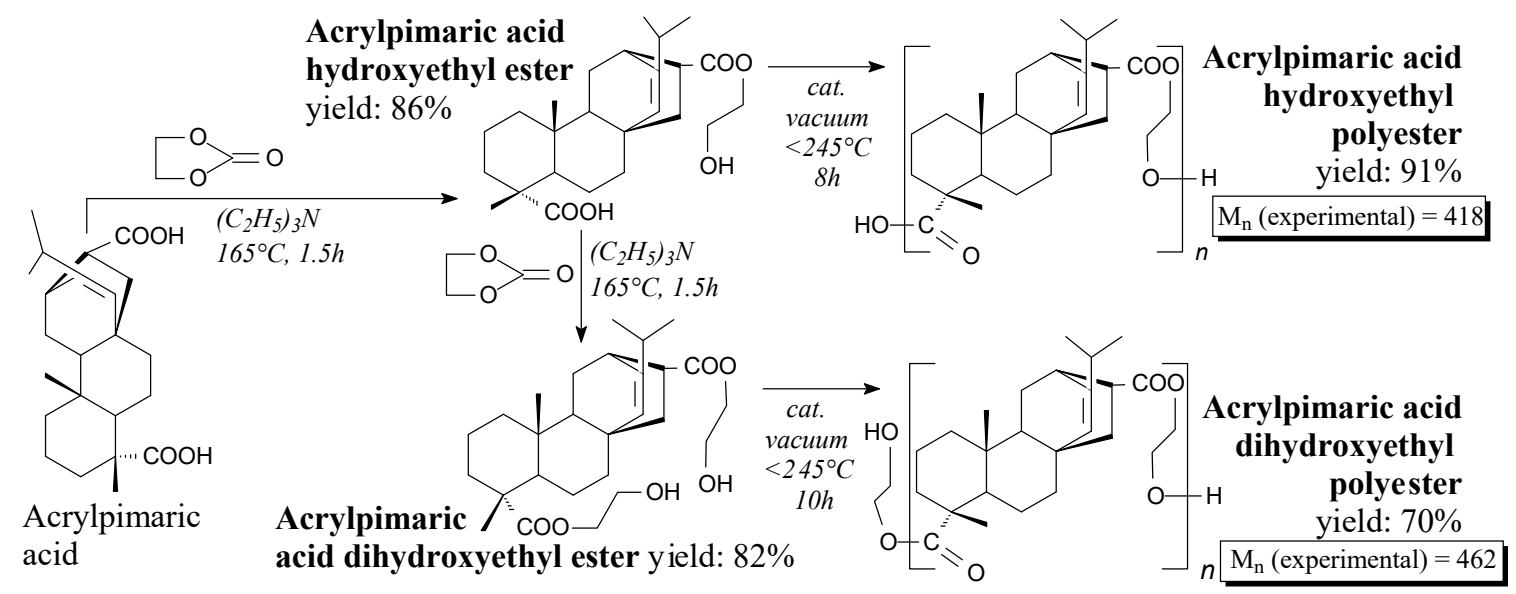

Scheme 86. Preparation of acrylpimaric acid hydroxyethyl polyester.

\section{Conclusions}

Rosin is a highly modifiable raw material for both low molecular weight products and polymers. Its natural origin is accompanied with low price and a diterpene chemical nature, which is ready to introduce useful reactive chemical groups, and it exhibits a stiff constitution improving many thermal, physical, mechanical and functional properties of the final materials. In recent years rosin-based chemicals have attracted growing interest. They offer great opportunities to produce useful products: resins, curing agents, surfactants, medicines, biocides, materials for biomedical application, elastomers, coatings, adhesives, sorbents and catalysts.

Taking into consideration the declared properties of the prepared chemicals they seem to be competitive alternatives to existing products on the market. This review presents well over 100 reproducible recipes. Sadly, some of the publications do not contain complete data, which makes it difficult to repeat the syntheses. According to our subjective opinion, the following information should be provided (or obvious) for a recipe to be considered as complete: product name, product morphology, substrate(s) names, reaction scheme, catalyst, media, temperature, pressure, time, yield and separation techniques. Figure 3 shows the number of complete and incomplete recipes in the individual parts of this review. Interestingly, the highest number of complete recipes (both absolute and relative) can be found among hardeners, resins and monomers, and also biologically active compounds. The most common missing parameter is yield. A large number of incomplete recipes in macromolecular 
compounds section may result from the fact that polymerizations are often carried out in order to achieve appropriate material properties, not specific yields. The summary presented in Figure 3 shows that resins, monomers, hardeners and biologically active compounds are the most completely described rosin-based chemicals in the recent decade, which makes them the most promising subjects for scaling-up and commercialization. However, this does not change the fact that rosin chemistry is able to deliver a serious amount of new environmentally-friendly solutions in many fields of science, medicine and engineering. The current review confirms this, and encourages further intensive research on rosin in the near future.

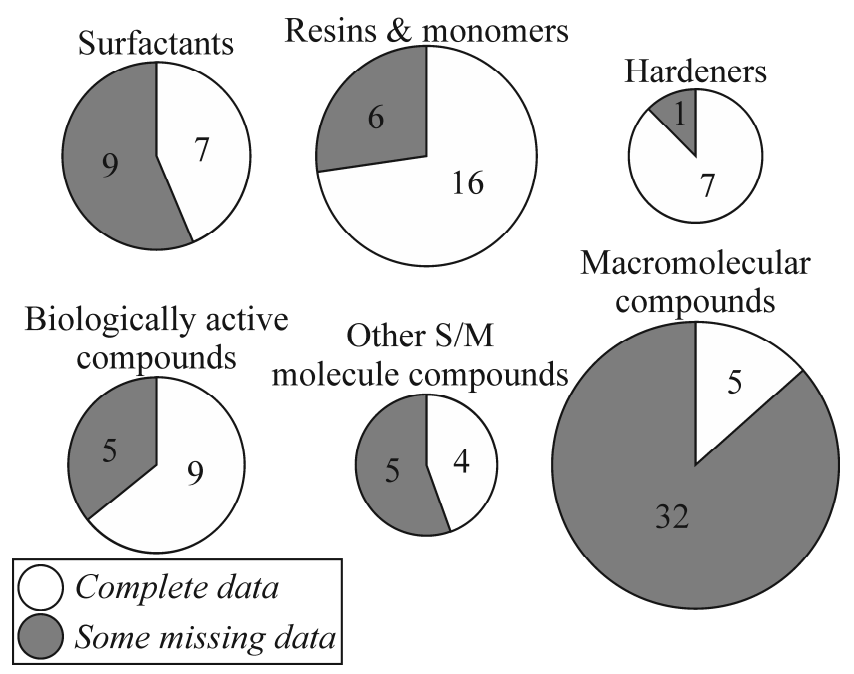

Figure 3. Number of complete and incomplete recipes presented in this review.

Funding: This work was financially supported by National Centre for Research and Development (project no. LIDER/7/0045/L-8/16/NCBR/2017).

Conflicts of Interest: The authors declare no conflict of interest.

\section{Abbreviations}

$\begin{array}{ll}\text { AA } & \text { adipic acid; } \\ \text { AIBA } & 2,2^{\prime} \text {-azobis(2-methylpropionamidine) dihydrochloride; } \\ \text { AIBN } & 2,2^{\prime} \text {-azobisisobutyronitrile; } \\ \text { ATRP } & \text { atom transfer radical polymerization; } \\ \text { BA } & \text { butyl acrylate; } \\ \text { Bu } & \text { butyl group; } \\ \text { Cat. } & \text { catalyst; } \\ \text { DA } & \text { dehydroabietic acid; } \\ \text { DBU } & 1,8 \text {-diazabicyclo[5.4.0]undec-7-ene; } \\ \text { DCC } & \text { N,N'-dicyclohexylcarbodiimide; } \\ \text { DDPD } & \text { dehydroabietyl phosphate diester; } \\ \text { DMAP } & \text { 4-dimethylaminopyridine; } \\ \text { DMF } & \text { dimethylformamide; } \\ \text { DMSO } & \text { dimethyl sulfoxide; } \\ \text { EC } & \text { ethyl cellulose; } \\ \text { EEW } & \text { epoxy equivalent weight; } \\ \text { Et } & \text { ethyl group; } \\ \text { HDMA Cl } & \text { hexadecyltrimethylammonium chloride; } \\ \text { HDTMAB } & \text { hexadecyl trimethyl ammonium bromide; } \\ \text { HPI } & \text { hydrophilic polyester intermediate; } \\ \text { HPLC } & \text { high-performance liquid chromatography; } \\ \text { HQ } & \text { hydroquinone; }\end{array}$




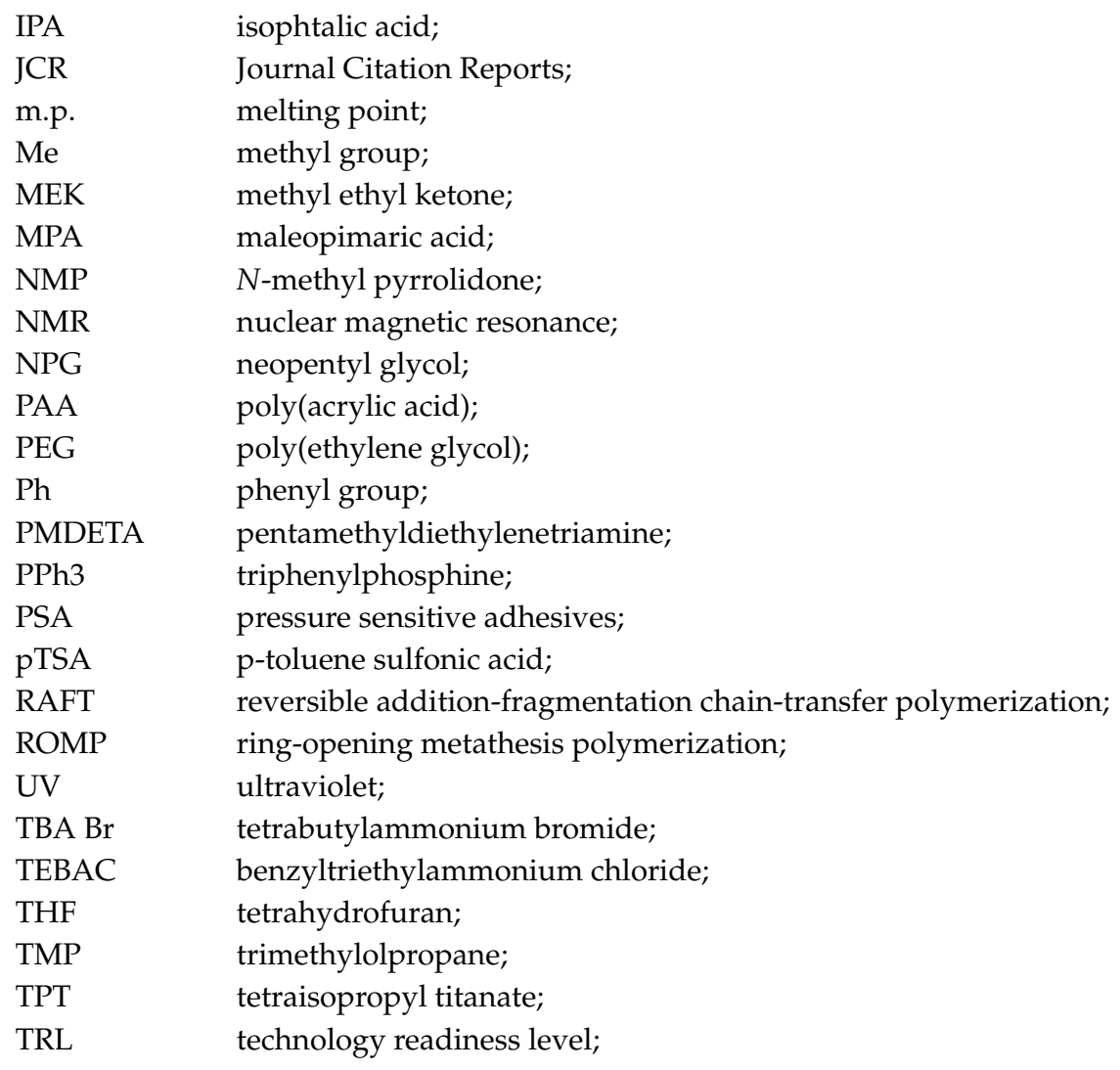

\section{References}

1. Silvestre, A.J.D.; Gandini, A. Chapter 4-Rosin: Major sources, properties and applications. In Monomers, Polymers and Composites from Renewable Resources; Elsevier: Amsterdam, The Netherlands, 2008; pp. 67-88, ISBN 978-0-08-045316-3.

2. Ma, S.; Li, T.; Liu, X.; Zhu, J. Research progress on bio-based thermosetting resins. Polym. Int. 2016, 65, 164-173. [CrossRef]

3. Ding, C.; Matharu, A.S. Recent developments on biobased curing agents: A review of their preparation and use. ACS Sustain. Chem. Eng. 2014, 2, 2217-2236. [CrossRef]

4. Wilbon, P.A.; Chu, F.; Tang, C. Progress in renewable polymers from natural terpenes, terpenoids, and rosin. Macromol. Rapid Commun. 2013, 34, 8-37. [CrossRef]

5. Kumar, S.; Samal, S.K.; Mohanty, S.; Nayak, S.K. Recent development of biobased epoxy resins: A review. Polym. Plast. Technol. 2018, 57, 133-155. [CrossRef]

6. Kumar, S.; Krishnan, S.; Mohanty, S.; Nayak, S.K. Synthesis and characterization of petroleum and biobased epoxy resins: A review. Polym. Int. 2018, 67, 815-839. [CrossRef]

7. Wang, Z.; Yuan, L.; Tang, C. Sustainable elastomers from renewable biomass. Acc. Chem. Res. 2017, 50, 1762-1773. [CrossRef]

8. Baroncini, E.A.; Yadav, S.K.; Palmese, G.R.; Stanzione, J.F. Recent advances in bio-based epoxy resins and bio-based epoxy curing agents. J. Appl. Polym. Sci. 2016, 133, 44103. [CrossRef]

9. Zia, K.M.; Noreen, A.; Zuber, M.; Tabasum, S.; Mujahid, M. Recent developments and future prospects on bio-based polyesters derived from renewable resources: A review. Int. J. Biol. Macromol. 2016, 82, 1028-1040. [CrossRef] [PubMed]

10. Gandini, A.; Lacerda, T.M. From monomers to polymers from renewable resources: Recent advances. Prog. Polym. Sci. 2015, 48, 1-39. [CrossRef]

11. Parthiban, A. Monomers and polymers derived from renewable or partially renewable resources. In Synthesis and Applications of Copolymers; Wiley-Blackwell: Hoboken, NJ, USA, 2014; pp. 101-124, ISBN 978-1-118-86016-8.

12. Narayanaperumal, S.; Rivera, D.G.; Silva, R.C.; Paixão, M.W. Terpene-derived bifunctional thioureas in asymmetric organocatalysis. ChemCatChem 2013, 5, 2756-2773. [CrossRef] 
13. Yadav, B.K.; Gidwani, B.; Vyas, A. Rosin: Recent advances and potential applications in novel drug delivery system. J. Bioact. Compat. Polym. 2016, 31, 111-126. [CrossRef]

14. Lu, Y.J.; Xu, R.S.; Zhao, Z.D.; Zhang, P.H.; Wang, M.X. Recent progress on derivation and chemical modification of rosin acids. Adv. Mater. Res. 2013, 785-786, 1111-1116. [CrossRef]

15. Robinson, V.; Bergfeld, W.F.; Belsito, D.V.; Klaassen, C.D.; Marks, J.G., Jr.; Shank, R.C.; Slaga, T.J.; Snyder, P.W.; Alan Andersen, F. Amended safety assessment of tall oil acid, sodium tallate, potassium tallate, and ammonium tallate. Int. J. Toxicol. 2009, 28, 252S-258S. [CrossRef]

16. Illing, H.P.A.; Malmfors, T.; Rodenburg, L. Skin sensitization and possible groupings for 'read across' for rosin based substances. Regul. Toxicol. Pharm. 2009, 54, 234-241. [CrossRef]

17. Botham, P.A.; Lees, D.; Illing, H.P.A.; Malmfors, T. On the skin sensitisation potential of rosin and oxidised rosin. Regul. Toxicol. Pharm. 2008, 52, 257-263. [CrossRef]

18. Błażek, K.; Datta, J. Renewable natural resources as green alternative substrates to obtain bio-based non-isocyanate polyurethanes-review. Crit. Rev. Environ. Sci. Technol. 2019, 1-39. [CrossRef]

19. Auvergne, R.; Caillol, S.; David, G.; Boutevin, B.; Pascault, J.-P. Biobased thermosetting epoxy: Present and future. Chem. Rev. 2014, 114, 1082-1115. [CrossRef]

20. Yadav, S.K.; Schmalbach, K.M.; Kinaci, E.; Stanzione, J.F.; Palmese, G.R. Recent advances in plant-based vinyl ester resins and reactive diluents. Eur. Polym. J. 2018, 98, 199-215. [CrossRef]

21. Liu, X.; Zhu, J. Chapter 19: Bio-based epoxies and composites as environmentally friendly alterinative materials. In Thermosets, 2nd ed.; Elsevier: Amsterdam, Holland, 2018; ISBN 978-0-08-101021-1.

22. Global Rosin Market-World Rosin Market Size, Trends, Analysis and Segment Forecasts to 2022-Rosin Industry Research, Outlook, Application, Product, Share, Growth, Key Opportunities, Dynamics, Analysis, Rosin Report-Grand View Research, Inc. Available online: https://www.grandviewresearch.com/industryanalysis/rosin-market (accessed on 29 May 2018).

23. La Colophane et Son Avenir Dans le Domaine du Sudoe. Available online: https://docplayer.net/21677781Chemical-division-what-is-rosin-rosin-rosin-is-a-solid-form-of-natural-solid-form-of-natural-resinobtained-from-conifers-and-mainly-pine-trees.html (accessed on 7 January 2019).

24. Chen, G.F. Developments in the field of rosin chemistry and its implications in coatings. Prog. Org. Coat. 1992, 20, 139-167. [CrossRef]

25. Mckeon, L.; Regan, F.; Burns, B.; Leonard, R. Determination of resin acid composition in rosin samples using cyclodextrin-modified capillary electrophoresis. J. Sep. Sci. 2014, 37, 2791-2796. [CrossRef]

26. Nguyen, T.T.H.; Li, S.; Li, J.; Liang, T. Micro-distribution and fixation of a rosin-based micronized-copper preservative in poplar wood. Int. Biodeter. Biodegr. 2013, 83, 63-70. [CrossRef]

27. Nguyen, T.T.H.; Li, S.; Li, J. The combined effects of copper sulfate and rosin sizing agent treatment on some physical and mechanical properties of poplar wood. Constr. Build. Mater. 2013, 40, 33-39. [CrossRef]

28. Hien, N.T.T.; Li, J.; Li, S. Effects of water-borne rosin on the fixation and decay resistance of copper-based preservative treated wood. Bioresources 2012, 7, 3573-3584.

29. Cavallaro, G.; Lazzara, G.; Milioto, S.; Parisi, F.; Ruisi, F. Nanocomposites based on esterified colophony and halloysite clay nanotubes as consolidants for waterlogged archaeological woods. Cellulose 2017, 24, 3367-3376. [CrossRef]

30. Han, Z.; Fina, A.; Malucelli, G. Thermal shielding performances of nano-structured intumescent coatings containing organo-modified layered double hydroxides. Prog. Org. Coat. 2015, 78, 504-510. [CrossRef]

31. Gaillard, Y.; Girard, M.; Monge, G.; Burr, A.; Ceretti, E.D.; Felder, E. Superplastic behavior of rosin/beeswax blends at room temperature. J. Appl. Polym. Sci. 2013, 128, 2713-2719. [CrossRef]

32. Bellotti, N.; del Amo, B.; Romagnoli, R. Quaternary ammonium "tannate" for antifouling coatings. Ind. Eng. Chem. Res. 2012, 51, 16626-16632. [CrossRef]

33. Pinori, E.; Berglin, M.; Brive, L.M.; Hulander, M.; Dahlström, M.; Elwing, H. Multi-seasonal barnacle (Balanus improvisus) protection achieved by trace amounts of a macrocyclic lactone (ivermectin) included in rosin-based coatings. Biofouling 2011, 27, 941-953. [CrossRef]

34. Gutierrez, J.; Tercjak, A. Natural gum rosin thin films nanopatterned by poly(styrene)-blockpoly(4-vinylpiridine) block copolymer. RSC Adv. 2014, 4, 32024-32030. [CrossRef]

35. Narayanan, M.; Loganathan, S.; Valapa, R.B.; Thomas, S.; Varghese, T.O. UV protective poly(lactic acid)/rosin films for sustainable packaging. Int. J. Biol. Macromol. 2017, 99, 37-45. [CrossRef] 
36. Yousaf, B.; Liu, G.; Abbas, Q.; Wang, R.; Ullah, H.; Mian, M.M.; Amina; Rashid, A. Enhanced removal of hexavalent chromium from aqueous media using a highly stable and magnetically separable rosin-biochar-coated TiO2@C nanocomposite. RSC Adv. 2018, 8, 25983-25996. [CrossRef]

37. Ma, C.; Zhang, W.; Zhang, G.; Qian, P.Y. Environmentally friendly antifouling coatings based on biodegradable polymer and natural antifoulant. ACS Sustain. Chem. Eng. 2017, 5, 6304-6309. [CrossRef]

38. Dong, Y.; Yan, Y.; Wang, K.; Li, J.; Zhang, S.; Xia, C.; Shi, S.Q.; Cai, L. Improvement of water resistance, dimensional stability, and mechanical properties of poplar wood by rosin impregnation. Eur. J. Wood Prod. 2016, 74, 177-184. [CrossRef]

39. Kim, S.-J.; Lee, B.-R.; Oh, E.-S. Application of a bio-derivative, rosin, as a binder additive for lithium titanium oxide electrodes in lithium-ion batteries. J. Power Sources 2015, 273, 608-612. [CrossRef]

40. Makhutov, N.A.; Ushakov, B.N.; Vasil'ev, I.E. Strength assessment and defect detection in welded pipeline seams by means of brittle tensosensitive coatings. Russ. Eng. Res. 2011, 31, 123-127. [CrossRef]

41. Zhang, Z.; Du, J.; Zhang, D.; Sun, H.; Yin, L.; Ma, L.; Chen, J.; Ma, D.; Cheng, H.-M.; Ren, W. Rosin-enabled ultraclean and damage-free transfer of graphene for large-area flexible organic light-emitting diodes. Nat. Commun. 2017, 8, 14560. [CrossRef] [PubMed]

42. Yu, X.; Bian, P.; Xue, Y.; Qian, X.; Yu, H.; Chen, W.; Hu, X.; Wang, P.; Wu, D.; Duan, Q.; et al. Combination of microsized mineral particles and rosin as a basis for converting cellulosic fibers into "sticky" superhydrophobic paper. Carbohydr. Polym. 2017, 174, 95-102. [CrossRef]

43. Singh, V.; Joshi, S.; Malviya, T. Carboxymethyl cellulose-rosin gum hybrid nanoparticles: An efficient drug carrier. Int. J. Biol. Macromol. 2018, 112, 390-398. [CrossRef]

44. Varshosaz, J.; Javanmard, S.H.; Soghrati, S.; Behdadfar, B. Magnetic chondroitin targeted nanoparticles for dual targeting of montelukast in prevention of in-stent restenosis. RSC Adv. 2016, 6, 12337-12347. [CrossRef]

45. Pomin, S.P.; Lima, I.A.d.; Pezarini, R.R.; Cavalcanti, O.A. Evaluation of rosin gum and EudragitßRS PO as a functional film coating material. AAPS PharmSciTech 2017, 18, 2854-2861. [CrossRef]

46. Moustafa, H.; El Kissi, N.; Abou-Kandil, A.I.; Abdel-Aziz, M.S.; Dufresne, A. PLA/PBAT bionanocomposites with antimicrobial natural rosin for green packaging. ACS Appl. Mater. Interfaces 2017, 9, 20132-20141. [CrossRef]

47. Nirmala, R.; Woo-il, B.; Navamathavan, R.; Kim, H.Y.; Park, S.-J. Preparation and characterizations of rosin based thin films and fibers. J. Nanosci. Nanotechnol. 2015, 15, 4653-4659. [CrossRef] [PubMed]

48. Nirmala, R.; Woo-il, B.; Navamathavan, R.; Kalpana, D.; Lee, Y.S.; Kim, H.Y. Influence of antimicrobial additives on the formation of rosin nanofibers via electrospinning. Colloid Surf. B 2013, 104, 262-267. [CrossRef] [PubMed]

49. Nirmala, R.; Baek, W.; Navamathavan, R.; Kim, T.W.; Kalpana, D.; Park, M.; Kim, H.Y.; Park, S.-J. Bactericidal efficacy of electrospun rosin/poly( $\varepsilon$-caprolactone) nanofibers. Macromol. Res. 2014, 22, 139-145. [CrossRef]

50. Nirmala, R.; Kalpana, D.; Navamathavan, R.; Park, M.; Kim, H.Y.; Park, S.-J. Antimicrobial activity of electrospun polyurethane nanofibers containing composite materials. Korean J. Chem. Eng. 2014, 31, 855-860. [CrossRef]

51. Bayer, I.S.; Tiwari, M.K.; Megaridis, C.M. Biocompatible poly(vinylidene fluoride)/cyanoacrylate composite coatings with tunable hydrophobicity and bonding strength. Appl. Phys. Lett. 2008, 93, 173902. [CrossRef]

52. Sharma, L.; Singh, C. Composite film developed from the blends of sesame protein isolate and gum rosin and their properties thereof. Polym. Compos. 2018, 39, 1480-1487. [CrossRef]

53. Park, J.Y.; Lee, Y.K.; Lee, D.-S.; Yoo, J.-E.; Shin, M.-S.; Yamabe, N.; Kim, S.-N.; Lee, S.; Kim, K.H.; Lee, H.-J.; et al. Abietic acid isolated from pine resin (Resina Pini) enhances angiogenesis in HUVECs and accelerates cutaneous wound healing in mice. J. Ethnopharmacol. 2017, 203, 279-287. [CrossRef]

54. Sakamoto, K.; Suzuki, Y.; Yamamura, H.; Ohya, S.; Muraki, K.; Imaizumi, Y. Molecular mechanisms underlying pimaric acid-induced modulation of voltage-gated K+ channels. J. Pharmacol. Sci. 2017, 133, 223-231. [CrossRef]

55. Kim, N.-H.; Son, Y.; Jeong, S.-O.; Hur, J.M.; Bang, H.S.; Lee, K.-N.; Kim, E.-C.; Chung, H.-T.; Pae, H.-O. Tetrahydroabietic acid, a reduced abietic acid, inhibits the production of inflammatory mediators in raw264.7 macrophages activated with lipopolysaccharide. J. Clin. Biochem. Nutr. 2010, 46, 119-125. [CrossRef]

56. Filippov, L.O.; Foucaud, Y.; Filippova, I.V.; Badawi, M. New reagent formulations for selective flotation of scheelite from a skarn ore with complex calcium minerals gangue. Miner. Eng. 2018, 123, 85-94. [CrossRef] 
57. Peng, H.; Shan, X.; Kang, J.; Ling, X.; Wang, D. Influence of rotary disk configurations on droplets characteristics in molten slag granulation for waste heat recovery. Appl. Therm. Eng. 2018, 135, $269-279$. [CrossRef]

58. Huang, F.; Li, H.; Yi, Z.; Wang, Z.; Xie, Y. The rheological properties of self-compacting concrete containing superplasticizer and air-entraining agent. Constr. Build. Mater. 2018, 166, 833-838. [CrossRef]

59. Patel, V.K.; Rawat, N. Physico-mechanical properties of sustainable Sagwan-teak wood flour/polyester composites with/without gum rosin. Sustain. Mater. Technol. 2017, 13, 1-8. [CrossRef]

60. Li, X.; Ge, S.; Yang, J.; Chang, R.; Liang, C.; Xiong, L.; Zhao, M.; Li, M.; Sun, Q. Synthesis and study the properties of StNPs/gum nanoparticles for salvianolic acid B-oral delivery system. Food Chem. 2017, 229, 111-119. [CrossRef]

61. Domene-López, D.; Guillén, M.M.; Martin-Gullon, I.; García-Quesada, J.C.; Montalbán, M.G. Study of the behavior of biodegradable starch/polyvinyl alcohol/rosin blends. Carbohydr. Polym. 2018, 202, 299-305. [CrossRef]

62. Kato, H.; Nakamura, A.; Matsubara, K. Dynamics and role of rosin acid molecules for preparation of well-dispersed CaCO3 colloidal suspensions. J. Nanopart. Res. 2012, 14, 950. [CrossRef]

63. Sifontes, Á.B.; Gutierrez, B.; Mónaco, A.; Yanez, A.; Díaz, Y.; Méndez, F.J.; Llovera, L.; Cañizales, E.; Brito, J.L. Preparation of functionalized porous nano- $\gamma-\mathrm{Al} 2 \mathrm{O} 3$ powders employing colophony extract. Biotechnol. Rep. 2014, 4, 21-29. [CrossRef]

64. Huang, X.; Qian, X.; Li, J.; Lou, S.; Shen, J. Starch/rosin complexes for improving the interaction of mineral filler particles with cellulosic fibers. Carbohydr. Polym. 2015, 117, 78-82. [CrossRef]

65. Soltes, J.; Zinkel, D.F. Chemistry of rosin. In Naval Stores: Production, Chemistry, Utilization; Pulp Chemicals Association: New York, NY, USA, 1989; ISBN 978-0-685-30903-2.

66. Nakamura, Y.; Sakai, Y.; Imamura, K.; Ito, K.; Fujii, S.; Urahama, Y. Effects of the compatibility of a polyacrylic block copolymer/tackifier blend on the phase structure and tack of a pressure-sensitive adhesive. J. Appl. Polym. Sci. 2012, 123, 2883-2893. [CrossRef]

67. Zhang, M.; Luo, Z.; Zhang, J.; Chen, S.; Zhou, Y. Effects of a novel phosphorus-nitrogen flame retardant on rosin-based rigid polyurethane foams. Polym. Degrad. Stab. 2015, 120, 427-434. [CrossRef]

68. Ding, K.; John, A.; Shin, J.; Lee, Y.; Quinn, T.; Tolman, W.B.; Hillmyer, M.A. High-performance pressuresensitive adhesives from renewable triblock copolymers. Biomacromolecules 2015, 16, 2537-2539. [CrossRef]

69. Ahn, B.K.; Sung, J.; Kim, N.; Kraft, S.; Sun, X.S. UV-curable pressure-sensitive adhesives derived from functionalized soybean oils and rosin ester. Polym. Int. 2013, 62, 1293-1301. [CrossRef]

70. Arrieta, M.P.; Samper, M.D.; Jiménez-López, M.; Aldas, M.; López, J. Combined effect of linseed oil and gum rosin as natural additives for PVC. Ind. Crop Prod. 2017, 99, 196-204. [CrossRef]

71. Guo, P.; Danish, M.; Du, P.; Kong, Z.; Guan, R. Viscoelastic and adhesive properties of polystyrenehydrogenated (3,4-polyisoprene and 1,4-polyisoprene)-polystyrene and polymethyl methacrylate-polybutyl acrylate-polymethyl methacrylate-based HMPSA. J. Adhes. Sci. Technol. 2014, 28, 417-433. [CrossRef]

72. Lee, S.; Lee, K.; Kim, Y.-W.; Shin, J. Preparation and characterization of a renewable pressure-sensitive adhesive system derived from $\varepsilon$-decalactone, l-lactide, epoxidized soybean oil, and rosin ester. ACS Sustain. Chem. Eng. 2015, 3, 2309-2320. [CrossRef]

73. Zhang, K.; Shang, S.; Sun, P.; Shen, M.; Wang, D. Hydrogenated rosin ester latexes/waterborne polyacrylate blends for pressure-sensitive adhesives. J. Appl. Polym. Sci. 2016, 133, 42965. [CrossRef]

74. Gao, L.; Zheng, G.; Zhou, Y.; Hu, L.; Feng, G. Thermal performances and fire behaviors of rosin-based rigid polyurethane foam nanocomposites. J. Therm. Anal. Calorim. 2015, 119, 411-424. [CrossRef]

75. Gao, L.; Zheng, G.; Zhou, Y.; Hu, L.; Feng, G.; Zhang, M. Synergistic effect of expandable graphite, diethyl ethylphosphonate and organically-modified layered double hydroxide on flame retardancy and fire behavior of polyisocyanurate-polyurethane foam nanocomposite. Polym. Degrad. Stab. 2014, 101, 92-101. [CrossRef]

76. Lee, H.J.; Choi, I.; Kim, K.; Kim, H.S.; Choi, W.M.; Oh, E.S. Performance of various rosin-derivatives as binder additives for lithium titanium oxide anodes. J. Electroanal. Chem. 2016, 782, 241-244. [CrossRef]

77. Moyano, M.A.; París, R.; Martín-Martínez, J.M. Assessment of the compatibility in hot melts by using different thermoanalytical methods. Ethylene/n-butyl acrylate (EBA) hot melts containing tackifiers of different nature. J. Therm. Anal. Calorim. 2017, 129, 1495-1503. [CrossRef] 
78. Moyano, M.A.; París, R.; Martín-Martínez, J.M. Changes in compatibility, tack and viscoelastic properties of ethylene n-butyl acrylate (EBA) copolymer-pentaerythritol rosin ester blend by adding microcrystalline wax, Fischer-Tropsch wax and mixture of waxes. Int. J. Adhes. Adhes. 2016, 65, 47-53. [CrossRef]

79. Yamamura, K.; Shitajima, K.; Fujii, S.; Nakamura, Y.; Hamada, Y.; Hagiwara, S.; Kishi, H.; Urahama, Y.; Sasaki, M. Temperature dependence of tack and pulse NMR analysis of polystyrene block copolymer/tackifier system. J. Adhes. Sci. Technol. 2013, 27, 2727-2740. [CrossRef]

80. Chu, H.-H.; Chiang, W.-L.; Chuang, K.S. Viscoelastic and adhesive properties of PMMA-b-PtBA with tackifier. Int. J. Adhes. Adhes. 2012, 38, 89-94. [CrossRef]

81. Atta, A.M.; Al-Lohedan, H.A. Influence of nonionic rosin surfactants on surface activity of silica particles and stability of oil in water emulsions. J. Surfactant. Deterg. 2014, 17, 1043-1053. [CrossRef]

82. Liu, X.; Xin, W.; Zhang, J. Rosin-based acid anhydrides as alternatives to petrochemical curing agents. Green Chem. 2009, 11, 1018-1025. [CrossRef]

83. Liu, X.Q.; Huang, W.; Jiang, Y.H.; Zhu, J.; Zhang, C.Z. Preparation of a bio-based epoxy with comparable properties to those of petroleum-based counterparts. Express Polym. Lett. 2012, 6, 293-298. [CrossRef]

84. Liu, X.; Zhang, J. High-performance biobased epoxy derived from rosin. Polym. Int. 2010, 59, 607-609. [CrossRef]

85. Li, P.; Wang, T.; Lei, F.; Tang, P.; Tan, X.; Liu, Z.; Shen, L. Rosin-based molecularly imprinted polymers as the stationary phase in high-performance liquid chromatography for selective separation of berberine hydrochloride. Polym. Int. 2014, 63, 1699-1706. [CrossRef]

86. Yu, C.L.; Zhang, F.A.; Gong, Q.H. Preparation of maleic rosin-based macromonomer and copolymerization with styrene and methyl methacrylate. Adv. Mater. Res. 2011, 236-238, 728-731. [CrossRef]

87. Li, X.; Li, M.; Li, J.; Lei, F.; Su, X.; Liu, M.; Li, P.; Tan, X. Synthesis and characterization of molecularly imprinted polymers with modified rosin as a cross-linker and selective SPE-HPLC detection of basic orange II in foods. Anal. Methods 2014, 6, 6397-6406. [CrossRef]

88. Ma, Q.; Liu, X.; Zhang, R.; Zhu, J.; Jiang, Y. Synthesis and properties of full bio-based thermosetting resins from rosin acid and soybean oil: The role of rosin acid derivatives. Green Chem. 2013, 15, 1300-1310. [CrossRef]

89. Lu, Y.; Zhao, Z.; Bi, L.; Chen, Y.; Wang, J.; Xu, S. Synthesis of a multifunctional hard monomer from rosin: the relationship of allyl structure in maleopimarate and UV-curing property. Sci. Rep. 2018, 8, 2399. [CrossRef]

90. Wang, J.; Yu, J.; Liu, Y.; Chen, Y.; Wang, C.; Tang, C.; Chu, F. Synthesis and characterization of a novel rosin-based monomer: Free-radical polymerization and epoxy curing. Green Mater. 2013, 1, 105-113. [CrossRef]

91. Si, H.; Liu, H.; Shang, S.; Song, J.; Liao, S.; Wang, D.; Song, Z. Maleopimaric acid-modified two-component waterborne polyurethane for coating applications. J. Appl. Polym. Sci. 2016, 133, 43292. [CrossRef]

92. Li, R.; Zhang, P.; Liu, T.; Muhunthan, B.; Xin, J.; Zhang, J. Use of hempseed-oil-derived polyacid and rosin-derived anhydride acid as cocuring agents for epoxy materials. ACS Sustain. Chem. Eng. 2018, 6, 4016-4025. [CrossRef]

93. Zhang, X.; Wu, Y.; Wei, J.; Tong, J.; Yi, X. Curing kinetics and mechanical properties of bio-based composite using rosin-sourced anhydrides as curing agent for hot-melt prepreg. Sci. China Technol. Sci. 2017, 60, 1318-1331. [CrossRef]

94. Liu, X.; Xin, W.; Zhang, J. Rosin-derived imide-diacids as epoxy curing agents for enhanced performance. Bioresour. Technol. 2010, 101, 2520-2524. [CrossRef]

95. Mustata, F.; Tudorachi, N.; Bicu, I. Thermosetting resins obtained via sequential photo and thermal crosslinking of epoxy resins. Curing kinetics, thermal properties and morphology. Compos. Part B 2013, 55, 470-478. [CrossRef]

96. Li, S.; Zou, T.; Liu, X.; Tao, M. Synthesis and characterization of benzoxazine monomers from rosin and their thermal polymerization. Des. Monomers Polym. 2014, 17, 40-46. [CrossRef]

97. Wang, H.; Liu, X.; Liu, B.; Zhang, J.; Xian, M. Synthesis of rosin-based flexible anhydride-type curing agents and properties of the cured epoxy. Polym. Int. 2009, 58, 1435-1441. [CrossRef]

98. Jaswal, S.; Gaur, B. Structure-property correlation study of bio-based multifunctional vinyl ester resin in presence of methacrylated lignin model compounds. Polym. Sci. Ser. B 2015, 57, 417-433. [CrossRef]

99. Qin, J.; Liu, H.; Zhang, P.; Wolcott, M.; Zhang, J. Use of eugenol and rosin as feedstocks for biobased epoxy resins and study of curing and performance properties. Polym. Int. 2014, 63, 760-765. [CrossRef] 
100. Zhai, Z.; Yan, X.; Song, Z.; Shang, S.; Rao, X. Annular and threadlike wormlike micelles formed by a bio-based surfactant containing an extremely large hydrophobic group. Soft Matter 2018, 14, 499-507. [CrossRef]

101. Lin, H.; Yang, M.; Tian, C.; Han, C.; Song, J.; Duan, J.; Jiang, J. Design of diversified self-assembly systems based on a natural rosin-based tertiary amine for doxorubicin delivery and excellent emulsification. Colloid Surf. B 2018, 165, 191-198. [CrossRef]

102. Zhai, Z.; Yan, X.; Xu, J.; Song, Z.; Shang, S.; Rao, X. Phase behavior and aggregation in a catanionic system dominated by an anionic surfactant containing a large rigid group. Chem. Eur. J. 2018, 24, 9033-9040. [CrossRef]

103. Li, J.; Zhang, G.; Shang, T.; Zhu, J. Synthesis, characterization and application of a dispersant based on rosin for coal-water slurry. Int. J. Min. Sci. Technol. 2014, 24, 695-699. [CrossRef]

104. Atta, M.A.; El-Mahdy, A.G.; Dyab, K.F.A.; Allohedan, A.H. Application of highly surface active cationic surfactants based on rosin as corrosion inhibitor for tubing steel during acidization of petroleum oil and gas wells. Int. J. Electrochem. Sci. 2013, 8, 9629-9643.

105. Lin, G.-S.; Dong, S.-Q.; Duan, W.-G.; Cen, B.; Xu, X.-T.; Yang, Z.-Q. Synthesis and biological activities of maleated rosin-based dithiourea compounds. Holzforschung 2013, 68, 549-554. [CrossRef]

106. Yao, G.; Ye, M.; Huang, R.; Li, Y.; Zhu, Y.; Pan, Y.; Liao, Z.-X.; Wang, H. Synthesis and antitumor activity evaluation of maleopimaric acid N-aryl imide atropisomers. Bioorg. Med. Chem. Lett. 2013, 23, 6755-6758. [CrossRef]

107. Wang, H.; Wang, H.; Zhou, G. Synthesis of rosin-based imidoamine-type curing agents and curing behavior with epoxy resin. Polym. Int. 2011, 60, 557-563. [CrossRef]

108. Xing, Y.; Zhang, W.; Song, J.; Zhang, Y.; Jiang, X.; Wang, R. Anticancer effects of a novel class rosin-derivatives with different mechanisms. Bioorg. Med. Chem. Lett. 2013, 23, 3868-3872. [CrossRef]

109. Xu, X.; Song, Z.; Shang, S.; Cui, S.; Rao, X. Synthesis and properties of novel rosin-based water-borne polyurethane. Polym. Int. 2011, 60, 1521-1526. [CrossRef]

110. Si, H.; Liu, H.; Shang, S.; Song, J.; Liao, S.; Wang, D.; Song, Z. Preparation and properties of maleopimaric acid-based polyester polyol dispersion for two-component waterborne polyurethane coating. Prog. Org. Coat. 2016, 90, 309-316. [CrossRef]

111. Xu, X.; Shang, S.; Song, Z.; Cui, S.; Wang, H.; Wang, D. Preparation and characterization of rosin-based waterborne polyurethane from maleopimaric acid polyester polyol. Bioresources 2011, 6, 2460-2470.

112. Liu, H.; Cui, S.; Shang, S.; Wang, D.; Song, J. Properties of rosin-based waterborne polyurethanes/cellulose nanocrystals composites. Carbohydr. Polym. 2013, 96, 510-515. [CrossRef]

113. Wu, Q.; Yao, G.; Zhang, Y.; Wang, H.; Yang, L.; Zhu, Y.; Pan, Y. In situ synthesis of rosin derived chiral derivatizing agents for 31P NMR assays of amine and alcohol enantiomers. Chem. Res. Chin. Univ. 2013, 29, 894-899. [CrossRef]

114. Yu, J.; Xu, N.; Liu, Z.; Wang, L. Novel one-component positive-tone chemically amplified i-line molecular glass photoresists. ACS Appl. Mater. Interfaces 2012, 4, 2591-2596. [CrossRef]

115. Tan, W.-X.; Lin, Z.-T.; Bu, H.-T.; Tian, Y.; Jiang, G.-B. Nano-micelles based on a rosin derivative as potent sorbents and sinking agents with high absorption capabilities for the removal of metal ions. RSC Adv. 2012, 2, 7279-7289. [CrossRef]

116. Xu, T.; Liu, H.; Song, J.; Shang, S.; Song, Z.; Zou, K.; Yang, C. Synthesis and characterization of maleated rosin-modified fluorosilicone resin and its fluorosilicone rubber. J. Appl. Polym. Sci. 2015, 132, 41888. [CrossRef]

117. Ha, Y.B.; Jin, M.Y.; Oh, S.S.; Ryu, D.H. Synthesis of an environmentally friendly phenol-free resin for printing ink. Bull. Korean Chem. Soc. 2012, 33, 3413-3416. [CrossRef]

118. Yang, M.; Chen, X.; Li, J.; Lin, H.; Zhang, S.; Han, C. Preparation of wood with better water-resistance properties by a one-step impregnation of maleic rosin. J. Adhes. Sci. Technol. 2018, 1-13. [CrossRef]

119. Yang, M.; Chen, X.; Lin, H.; Han, C.; Zhang, S. A simple fabrication of superhydrophobic wood surface by natural rosin based compound via impregnation at room temperature. Eur. J. Wood Prod. 2018, 76, 1417-1425. [CrossRef]

120. Li, H.; Lin, R.; He, J.; Long, H.; Liao, W.; Chen, Q. Effect of pretreatment on the enzymatic synthesis of rosin acid starch. New J. Chem. 2016, 40, 2856-2862. [CrossRef]

121. Tudorachi, N.; Mustaţă, F.; Bicu, I. Thermal decomposition of some Diels-Alder adducts of resin acids: study of kinetics process. J. Anal. Appl. Pyrol. 2012, 98, 106-114. [CrossRef] 
122. Deng, L.; Ha, C.; Sun, C.; Zhou, B.; Yu, J.; Shen, M.; Mo, J. Properties of bio-based epoxy resins from rosin with different flexible chains. Ind. Eng. Chem. Res. 2013, 52, 13233-13240. [CrossRef]

123. Mandal, M.; Borgohain, P.; Begum, P.; Deka, R.C.; Maji, T.K. Property enhancement and DFT study of wood polymer composites using rosin derivatives as co-monomers. New J. Chem. 2018, 42, 2260-2269. [CrossRef]

124. Yu, C.; Wang, X.; Chen, C.; Zhang, F. Preparation of polystyrene microspheres using rosin-acrylic acid diester as a cross-linking agent. Ind. Eng. Chem. Res. 2014, 53, 2244-2250. [CrossRef]

125. Yan, X.; Zhai, Z.; Song, Z.; Shang, S.; Rao, X. Synthesis and properties of polyester-based polymeric surfactants from diterpenic rosin. Ind. Crop. Prod. 2017, 108, 371-378. [CrossRef]

126. Li, T.; Liu, X.; Jiang, Y.; Ma, S.; Zhu, J. Bio-based shape memory epoxy resin synthesized from rosin acid. Iran. Polym. J. 2016, 25, 957-965. [CrossRef]

127. Deng, L.; Shen, M.; Yu, J.; Wu, K.; Ha, C. Preparation, characterization, and flame retardancy of novel rosin-based siloxane epoxy resins. Ind. Eng. Chem. Res. 2012, 51, 8178-8184. [CrossRef]

128. Lin, H.X.; Yang, M.S.; Li, J.; Chen, X.Y.; Jiang, J.X.; Han, C.R. A novel bola-type rosin-based functional surfactant and its synergistic effect with natural surfactant saponin. J. Surfactant. Deterg. 2017, 20, 1205-1212. [CrossRef]

129. Gao, Y.; Li, L.; Chen, H.; Li, J.; Song, Z.; Shang, S.; Song, J.; Wang, Z.; Xiao, G. High value-added application of rosin as a potential renewable source for the synthesis of acrylopimaric acid-based botanical herbicides. Ind. Crop. Prod. 2015, 78, 131-140. [CrossRef]

130. Gao, Y.; Li, J.; Song, Z.; Song, J.; Shang, S.; Xiao, G.; Wang, Z.; Rao, X. Turning renewable resources into value-added products: Development of rosin-based insecticide candidates. Ind. Crop Prod. 2015, 76, 660-671. [CrossRef]

131. Li, J.; Li, S.; Li, S.; Wang, J.; Liu, D. Synthesis of a rosin amide and its inhibition of wood decay fungi. Adv. Mater. Res. 2010, 113-116, 2232-2236. [CrossRef]

132. Liu, G.; Chen, C.; Wu, G.; Kong, Z. Preparation and antimicrobial activity of rosin-based carbamate group-containing quaternary ammonium salt derivatives. Bioresources 2013, 8, 4218-4226. [CrossRef]

133. Chen, Z.; Li, S.; Tian, B.; Liang, T.; Jin, Y. Synthesis and characterization of a rosin gemini surfactant. Mater. Sci. Forum 2011, 685, 285-290. [CrossRef]

134. Liang, T.; Li, S.; Li, S.; Zhang, L. Synthesis of N-(3-rosin acyloxy-2-hydroxyl) propyl-N,N diethanolamine and its anti-fungal activity. Adv. Mater. Res. 2011, 280, 124-127. [CrossRef]

135. Jin, Y.; Li, S.; Liang, T.; Chen, Z. Synthesis of quaternary ammonium salt from rosin and its inhibition to some wood decay fungi. Mater. Sci. Forum 2011, 685, 291-297. [CrossRef]

136. Li, S.; Wang, J.; Li, S.; Chen, Z.; Tian, B.; Wang, D. Synthesis and characterization of bisN-(3-rosin acyloxy-2-hydroxyl) propyl-N,N dimethylamine. Adv. Mater. Res. 2010, 113-116, 2197-2200. [CrossRef]

137. Li, M.; Zhang, J.; Huang, K.; Li, S.; Jiang, J.; Xia, J. Mixed calcium and zinc salts of dicarboxylic acids derived from rosin and dipentene: preparation and thermal stabilization for PVC. RSC Adv. 2014, 4, 63576-63585. [CrossRef]

138. Mustata, F.; Bicu, I. A novel route for synthesizing esters and polyesters from the Diels-Alder adduct of levopimaric acid and acrylic acid. Eur. Polym. J. 2010, 46, 1316-1327. [CrossRef]

139. Mustata, F.R.; Tudorachi, N.; Bicu, I. Biobased epoxy matrix from diglycidyl ether of bisphenol A and epoxidized corn oil, cross-linked with Diels-Alder adduct of levopimaric acid with acrylic acid. Ind. Eng. Chem. Res. 2013, 52, 17099-17110. [CrossRef]

140. Li, J.; Lin, H.X.; Chen, X.Y.; Zhu, J.R.; Yang, M.S.; Yang, J.; Han, C.R. Self-assembled structures and excellent surface properties of a novel anionic phosphate diester surfactant derived from natural rosin acids. J. Colloid Interface Sci. 2017, 486, 67-74. [CrossRef] [PubMed]

141. Gu, W.; Wang, S. Synthesis and antimicrobial activities of novel $1 \mathrm{H}$-dibenzo[a,c]carbazoles from dehydroabietic acid. Eur. J. Med. Chem. 2010, 45, 4692-4696. [CrossRef]

142. Lu, C.; Yu, J.; Wang, C.; Wang, J.; Chu, F. Fabrication of UV-absorbent cellulose-rosin based thermoplastic elastomer via "graft from" ATRP. Carbohydr. Polym. 2018, 188, 128-135. [CrossRef]

143. Li, W.; Xie, D.; Song, B.; Feng, L.; Pei, X.; Cui, Z. Synthesis and characterization of ordered mesoporous silica using rosin-based gemini surfactants. J. Mater. Sci. 2018, 53, 2434-2442. [CrossRef]

144. Zhang, H.; Yang, Y.; Shen, M.; Shang, S.; Song, J.; Jiang, J.; Song, Z. Soybean oil-based thermoset reinforced with rosin-based monomer. Iran. Polym. J. 2018, 27, 405-411. [CrossRef] 
145. Zheng, Y.; Yao, K.; Lee, J.; Chandler, D.; Wang, J.; Wang, C.; Chu, F.; Tang, C. Well-defined renewable polymers derived from gum rosin. Macromolecules 2010, 43, 5922-5924. [CrossRef]

146. Ding, W.; Wang, S.; Yao, K.; Ganewatta, M.S.; Tang, C.; Robertson, M.L. Physical Behavior of Triblock Copolymer Thermoplastic Elastomers Containing Sustainable Rosin-Derived Polymethacrylate End Blocks. ACS Sustain. Chem. Eng. 2017, 5, 11470-11480. [CrossRef]

147. Yao, K.; Wang, J.; Zhang, W.; Lee, J.S.; Wang, C.; Chu, F.; He, X.; Tang, C. Degradable rosin-ester-caprolactone graft copolymers. Biomacromolecules 2011, 12, 2171-2177. [CrossRef]

148. Yu, J.; Liu, Y.P.; Wang, C.P.; Chen, Y.; Wang, J.F.; Chu, F.X. Preparation and characterization of novel naturally renewable resin acid based monomer. Adv. Mater. Res. 2013, 712-715, 139-146. [CrossRef]

149. Zhang, H.; Jiang, J.; Shang, S.; Song, Z.; Song, J. Novel, rosin-based, hydrophobically modified cationic polyacrylamide for kaolin suspension flocculation. J. Appl. Polym. Sci. 2018, 135, 46637. [CrossRef]

150. Gu, W.; Qiao, C.; Wang, S.-F.; Hao, Y.; Miao, T.-T. Synthesis and biological evaluation of novel N-substituted $1 \mathrm{H}$-dibenzo[a,c]carbazole derivatives of dehydroabietic acid as potential antimicrobial agents. Bioorg. Med. Chem. Lett. 2014, 24, 328-331. [CrossRef] [PubMed]

151. Luo, D.; Ni, Q.; Ji, A.; Gu, W.; Wu, J.; Jiang, C. Dehydroabietic acid derivative QC4 induces gastric cancer cell death via oncosis and apoptosis. BioMed Res. Int. 2016, 2016, 2581061. [CrossRef]

152. Gowda, R.; Madhunapantula, S.V.; Kuzu, O.F.; Sharma, A.; Robertson, G.P. Targeting multiple key signaling pathways in melanoma using leelamine. Mol. Cancer Ther. 2014, 13, 1679-1689. [CrossRef] [PubMed]

153. Kuzu, O.F.; Gowda, R.; Sharma, A.; Robertson, G.P. Leelamine mediates cancer cell death through inhibition of intracellular cholesterol transport. Mol. Cancer Ther. 2014, 13, 1690-1703. [CrossRef] [PubMed]

154. Gowda, R.; Madhunapantula, S.V.; Sharma, A.; Kuzu, O.F.; Robertson, G.P. Nanolipolee-007, a novel nanoparticle-based drug containing leelamine for the treatment of melanoma. Mol. Cancer Ther. 2014, 13, 2328-2340. [CrossRef]

155. Singh, K.B.; Ji, X.; Singh, S.V. Therapeutic potential of leelamine, a novel inhibitor of androgen receptor and castration-resistant prostate cancer. Mol. Cancer Ther. 2018, 17, 2079-2090. [CrossRef] [PubMed]

156. Li, C.; Liu, X.; Zhu, J.; Zhang, C.; Guo, J. Synthesis, characterization of a rosin-based epoxy monomer and its comparison with a petroleum-based counterpart. J. Macromol. Sci. A 2013, 50, 321-329. [CrossRef]

157. Liu, X.; Zhang, R.; Li, T.; Zhu, P.; Zhuang, Q. Novel Fully Biobased Benzoxazines from Rosin: Synthesis and Properties. ACS Sustainable Chem. Eng. 2017, 5, 10682-10692. [CrossRef]

158. Wang, P.; Chen, S.X.; Zhao, Z.D.; Wang, Z.; Fan, G. Synthesis of ordered porous SiO2 with pores on the border between the micropore and mesopore regions using rosin-based quaternary ammonium salt. RSC Adv. 2015, 5, 11223-11228. [CrossRef]

159. Song, F.; Wang, P.; Chen, S.; Wang, Z.; Fan, G. Ordered lamellar supermicroporous titania templating by rosin-derived quaternary ammonium salt. PLoS ONE 2017, 12, e0180178. [CrossRef] [PubMed]

160. Liu, Y.; Li, C.; Dai, J.; Jiang, Y.; Liu, X.; Zhu, J. Synthesis of multifunctional monomers from rosin for the properties enhancement of soybean-oil based thermosets. Sci. China Technol. Sci. 2017, 60, 1332-1338. [CrossRef]

161. Yang, Y.; Shen, M.; Huang, X.; Zhang, H.; Shang, S.; Song, J. Synthesis and performance of a thermosetting resin: Acrylated epoxidized soybean oil curing with a rosin-based acrylamide. J. Appl. Polym. Sci. 2017, 134, 44545. [CrossRef]

162. Huo, L.; Wang, D.; Liu, H.; Jia, P.; Gao, J. Cytoxicity, dynamic and thermal properties of bio-based rosin-epoxy resin/ castor oil polyurethane/ carbon nanotubes bio-nanocomposites. J. Biomater. Sci. Polym. Ed. 2016, 27, 1100-1114. [CrossRef] [PubMed]

163. El-Ghazawy, R.A.; El-Saeed, A.M.; Al-Shafey, H.I.; Abdul-Raheim, A.-R.M.; El-Sockary, M.A. Rosin based epoxy coating: Synthesis, identification and characterization. Eur. Polym. J. 2015, 69, 403-415. [CrossRef]

164. Brocas, A.-L.; Llevot, A.; Mantzaridis, C.; Cendejas, G.; Auvergne, R.; Caillol, S.; Carlotti, S.; Cramail, H. Epoxidized rosin acids as co-precursors for epoxy resins. Des. Monomers Polym. 2014, 17, 301-310. [CrossRef]

165. Mantzaridis, C.; Brocas, A.-L.; Llevot, A.; Cendejas, G.; Auvergne, R.; Caillol, S.; Carlotti, S.; Cramail, H. Rosin acid oligomers as precursors of DGEBA-free epoxy resins. Green Chem. 2013, 15, 3091-3098. [CrossRef]

166. Liu, Y.; Yao, K.; Chen, X.; Wang, J.; Wang, Z.; Ploehn, H.J.; Wang, C.; Chu, F.; Tang, C. Sustainable thermoplastic elastomers derived from renewable cellulose, rosin and fatty acids. Polym. Chem. 2014, 5, 3170-3181. [CrossRef] 
167. Wang, J.; Yuan, L.; Wang, Z.; Rahman, M.A.; Huang, Y.; Zhu, T.; Wang, R.; Cheng, J.; Wang, C.; Chu, F.; et al. Photoinduced metal-free atom transfer radical polymerization of biomass-based monomers. Macromolecules 2016, 49, 7709-7717. [CrossRef]

168. An, S.Y.; Hong, S.H.; Tang, C.; Oh, J.K. Rosin-based block copolymer intracellular delivery nanocarriers with reduction-responsive sheddable coronas for cancer therapy. Polym. Chem. 2016, 7, 4751-4760. [CrossRef]

169. Wang, J.; Yao, K.; Korich, A.L.; Li, S.; Ma, S.; Ploehn, H.J.; Iovine, P.M.; Wang, C.; Chu, F.; Tang, C. Combining renewable gum rosin and lignin: Towards hydrophobic polymer composites by controlled polymerization. J. Polym. Sci. A 2011, 49, 3728-3738. [CrossRef]

170. Wilbon, P.A.; Zheng, Y.; Yao, K.; Tang, C. Renewable rosin acid-degradable caprolactone block copolymers by atom transfer radical polymerization and ring-opening polymerization. Macromolecules 2010, 43, 8747-8754. [CrossRef]

171. Wang, J.-F.; Lin, M.-T.; Wang, C.-P.; Chu, F.-X. Study on the synthesis, characterization, and kinetic of bulk polymerization of disproportionated rosin ( $\beta$-acryloxyl ethyl) ester. J. Appl. Polym. Sci. 2009, 113, 3757-3765. [CrossRef]

172. Duan, W.; Chen, C.; Jiang, L.; Li, G.H. Preparation and characterization of the graft copolymer of chitosan with poly[rosin-(2-acryloyloxy)ethyl ester]. Carbohydr. Polym. 2008, 73, 582-586. [CrossRef] [PubMed]

173. Liu, B.; Nie, J.; He, Y. From rosin to high adhesive polyurethane acrylate: Synthesis and properties. Int. J. Adhes. Adhes. 2016, 66, 99-103. [CrossRef]

174. Do, H.-S.; Park, J.-H.; Kim, H.-J. Synthesis and characteristics of photoactive-hydrogenated rosin epoxy methacrylate for pressure sensitive adhesives. J. Appl. Polym. Sci. 2009, 111, 1172-1176. [CrossRef]

175. Yan, X.; Zhai, Z.; Song, Z.; Shang, S.; Rao, X. Synthesis of comb-like polymeric surfactants with a tricyclic rigid core and their use as dispersants in pymetrozine water suspension concentrates. RSC Adv. 2017, 7, 55741-55747. [CrossRef]

176. Do, H.-S.; Park, J.-H.; Kim, H.-J. UV-curing behavior and adhesion performance of polymeric photoinitiators blended with hydrogenated rosin epoxy methacrylate for UV-crosslinkable acrylic pressure sensitive adhesives. Eur. Polym. J. 2008, 44, 3871-3882. [CrossRef]

177. Lu, Y.; Zhao, Z.; Chen, Y.; Wang, J.; Xu, S.; Gu, Y. Synthesis of allyl acrylpimarate by microwave irradiation and phase-transfer catalytic reaction and its UV-curing reactions as a new monomer. Prog. Org. Coat. 2017, 109, 9-21. [CrossRef]

178. Li, T.; Liu, X.; Jiang, Y.; Ma, S.; Zhu, J. Synthesis of epoxy curing agents containing different ring structures and properties investigation of the cured resins. J. Appl. Polym. Sci. 2016, 133, 44219. [CrossRef]

179. Qin, J.; Chen, X.; Yu, J.; Wang, Y.; Tian, Y.; Wu, S. Nonisothermal crystallization kinetics of isotactic polypropylene containing nucleating agent and dispersant. J. Appl. Polym. Sci. 2010, 117, 1047-1054. [CrossRef]

180. Wang, J.; Dou, Q. Crystallization behavior and optical and mechanical properties of isotactic polypropylene nucleated with rosin-based nucleating agents. Polym. Int. 2008, 57, 233-239. [CrossRef]

181. Lu, Y.; Wang, M.; Zhao, Z.; Chen, Y.; Xu, S.; Wang, J.; Bi, L. Facile synthesis of allyl resinate monomer in an aqueous solution under microwave irradiation. J. Chem. Sci. 2015, 127, 1183-1190. [CrossRef]

182. Lu, Y.; Zhao, Z.; Gu, Y.; Chen, Y.; Bi, L. Synthesis of rosin allyl ester and its UV-curing characteristics. Polym. J. 2011, 43, 869-873. [CrossRef]

183. Wang, H.; Liu, B.; Liu, X.; Zhang, J.; Xian, M. Synthesis of biobased epoxy and curing agents using rosin and the study of cure reactions. Green Chem. 2008, 10, 1190-1196. [CrossRef]

184. Wang, H.; He, C.; Pan, Y.; Yao, G.; Wu, Q.; Deng, H. Synthesis and amines enantiomeric recognition ability of binaphthyl-appended 22-crown-6 ethers derived from rosin acid. J. Incl. Phenom. Macrocycl. Chem. 2012, 73, 177-183. [CrossRef]

185. Mustata, F.R.; Tudorachi, N. Epoxy resins cross-linked with rosin adduct derivatives. Cross-linking and thermal behaviors. Ind. Eng. Chem. Res. 2010, 49, 12414-12422. [CrossRef]

186. Zhang, L.; Jiang, Y.; Xiong, Z.; Liu, X.; Na, H.; Zhang, R.; Zhu, J. Highly recoverable rosin-based shape memory polyurethanes. J. Mater. Chem. A 2013, 1, 3263-3267. [CrossRef]

187. Pietrzak, K.; Kirpluks, M.; Cabulis, U.; Ryszkowska, J. Effect of the addition of tall oil-based polyols on the thermal and mechanical properties of ureaurethane elastomers. Polym. Degrad. Stab. 2014, 108, 201-211. [CrossRef] 
188. Zhan, S.H.; Jiang, X.H.; Li, J.; Meng, Z.; Chen, L.L.; Han, C.R. Controlled synthesis of hydroxyapatite using a novel natural rosin-based surfactant. Nano 2017, 12, 1750098. [CrossRef]

189. Liang, T.; Zhang, Y.; Li, S.; Nguyen, T.T.H. Synthesis, characterization, and bioactivity of rosin quaternary ammonium salt derivatives. Bioresources 2013, 8, 735-742. [CrossRef]

190. Li, J.; Gao, Y.; Shang, S.; Rao, X.; Song, J.; Wang, Z. Synthesis and quantitative structure-activity relationship (QSAR) studies of novel rosin-based diamide insecticides. RSC Adv. 2014, 4, 58190-58199. [CrossRef]

191. Atta, A.; El-Mahdy, G.; Al-Lohedan, H.; Al-Hussain, S.; Atta, A.M.; El-Mahdy, G.A.; Al-Lohedan, H.A.; Al-Hussain, S.A. Synthesis of environmentally friendly highly dispersed magnetite nanoparticles based on rosin cationic surfactants as thin film coatings of steel. Int. J. Mol. Sci. 2014, 15, 6974-6989. [CrossRef] [PubMed]

192. Atta, A.M.; El-Saeed, A.M.; El-Mahdy, G.M.; Al-Lohedan, H.A. Application of magnetite nano-hybrid epoxy as protective marine coatings for steel. RSC Adv. 2015, 5, 101923-101931. [CrossRef]

193. Ishtikhar, M.; Rahisuddin; Khan, M.V.; Khan, R.H. Anti-aggregation property of thymoquinone induced by copper-nanoparticles: A biophysical approach. Int. J. Biol. Macromol. 2016, 93, 1174-1182. [CrossRef] [PubMed]

194. Ishtikhar, M.; Chandel, T.I.; Ahmad, A.; Ali, M.S.; Al-lohadan, H.A.; Atta, A.M.; Khan, R.H. Rosin surfactant QRMAE can be utilized as an amorphous aggregate inducer: a case study of mammalian serum albumin. PLoS ONE 2015, 10, e0139027. [CrossRef] [PubMed]

195. Ishtikhar, M.; Usmani, S.S.; Gull, N.; Badr, G.; Mahmoud, M.H.; Khan, R.H. Inhibitory effect of copper nanoparticles on rosin modified surfactant induced aggregation of lysozyme. Int. J. Biol. Macromol. 2015, 78, 379-388. [CrossRef]

196. Wang, H.; Nguyen, T.T.H.; Li, S.; Liang, T.; Zhang, Y.; Li, J. Quantitative structure-activity relationship of antifungal activity of rosin derivatives. Bioorg. Med. Chem. Lett. 2015, 25, 347-354. [CrossRef]

197. Chen, Z.; Li, S.; Tian, B.; Liang, T.; Jin, Y. Synthesis of a rosin gemini surfactant and its properties. Environ. Eng. Sci. 2011, 29, 606-610. [CrossRef]

198. Wang, P.; Zhao, Z.D.; He, L.Z.; Bi, L.W.; Chen, Y.X. Fabrication of mesoporous ZrO2 by using rosin-based quaternary ammonium salt. Adv. Mater. Res. 2011, 239-242, 3257-3261. [CrossRef]

199. Deng, W.; Zhang, Y.; Zhong, Y.; Peng, J. Synthesis and thermodynamic properties of rosin-based cationic gemini surfactants. J. Surfactant. Deterg. 2014, 17, 453-458. [CrossRef]

200. Liu, G.; Wu, G.; Chen, J.; Kong, Z. Synthesis, modification and properties of rosin-based non-isocyanate polyurethanes coatings. Prog. Org. Coat. 2016, 101, 461-467. [CrossRef]

201. Wang, H.; Tian, X.; Yang, D.; Pan, Y.; Wu, Q.; He, C. Synthesis and enantiomeric recognition ability of 22-crown-6 ethers derived from rosin acid and BINOL. Tetrahedron Asymmetry 2011, 22, 381-386. [CrossRef]

202. Nong, W.J.; Chen, X.P.; Liang, J.Z.; Wang, L.L.; Tong, Z.F.; Huang, K.L.; Wu, R.; Xie, Q.R.; Jia, Y.H.; Li, K.X. Isolation and characterization of abietic acid. Adv. Mater. Res. 2014, 887-888, 551-556. [CrossRef]

203. Zhang, G.; Jiang, C.; Wang, Z.; Chen, W.; Gu, W.; Ding, Y. Dehydroabietic acid derivative QC2 induces oncosis in hepatocellular carcinoma cells. Biomed Res. Int. 2014, 2014, 682197. [CrossRef]

204. Li, J.; Song, J.; Shang, S.-B.; Rao, X.-P.; Gao, Y.-Q. Syntheses and antibacterial activity of Schiff bases from 16-isopropyl-5, 9-dimethyltetracyclo [10.2.2.01, 10.04, 9] hexadec-15-ene-5, 14-dicarboxylic acid. Nat. Prod. Res. 2013, 27, 702-710. [CrossRef] [PubMed]

205. Li, J.; Rao, X.; Shang, S.; Gao, Y.; Song, J. Synthesis and antibacterial activity of amide derivatives from acrylopimaric acid. Bioresources 2012, 7, 1961-1971. [CrossRef]

206. Shi, Z.; Wang, Y.; Nie, Y.; Yao, X. Synthesis and characterization of glucose dehydroabietate. Adv. Mater. Res. 2012, 396-398, 1260-1264. [CrossRef]

207. Liu, Y.; Li, L.; Liu, S.; Xie, C.; Yu, S. The selective hydrogenation of rosin to hydroabietic content using Pd/SBA-15 as catalysts. Res. Chem. Intermed. 2017, 43, 1211-1221. [CrossRef]

208. Huang, Y.; Wang, L.; Chen, X.; Wei, X.; Liang, J.; Li, W. Intrinsic kinetics study of rosin hydrogenation on a nickel catalyst supported on spent equilibrium catalyst. RSC Adv. 2017, 7, 25780-25788. [CrossRef]

209. Wang, M.M.; Liu, S.W.; Li, L.; Yu, S.T.; Xie, C.X.; Song, Z.Q. Hydrogenation of rosin over PVP-stabilized Pd nanoparticles in aqueous/organic biphasic system. Res. Chem. Intermed. 2016, 42, 6181-6190. [CrossRef]

210. Zhang, D.; Zhou, D.; Wei, X.; Liang, J.; Chen, X.; Wang, L. Green catalytic conversion of hydrogenated rosin to glycerol esters using subcritical CO2 in water and the associated kinetics. J. Supercrit. Fluid. 2017, 125, 12-21. [CrossRef] 
211. Bernas, A.; Salmi, T.; Murzin, D.Y.; Mikkola, J.-P.; Rintola, M. Catalytic transformation of abietic acid to hydrocarbons. Top. Catal. 2012, 55, 673-679. [CrossRef]

212. Wang, L.; Huang, C.; Chen, J.; Wei, X.; Chen, X.; Liang, J. Catalyst-free biodiesel production from industrial rosin residue (dark-grade rosin) using supercritical methanol. Waste Biomass Valori. 2018, 9, 1191-1198. [CrossRef]

213. Kulikov, A.B.; Onishchenko, M.I.; Maksimov, A.L.; Lysenko, S.V.; Karakhanov, E.A. Hydroconversion of rosin acids in the presence of Pt-containing Al-HMS mesoporous aluminosilicate. Pet. Chem. 2016, 56, 717-723. [CrossRef]

214. Huang, Y.; Chen, X.; Deng, Y.; Zhou, D.; Wang, L. A novel nickel catalyst derived from layered double hydroxides (LDHs) supported on fluid catalytic cracking catalyst residue (FC3R) for rosin hydrogenation. Chem. Eng. J. 2015, 269, 434-443. [CrossRef]

215. Tong, D.S.; Zheng, Y.M.; Yu, W.H.; Wu, L.M.; Zhou, C.H. Catalytic cracking of rosin over acid-activated montmorillonite catalysts. Appl. Clay Sci. 2014, 100, 123-128. [CrossRef]

216. Bicu, I.; Mustata, F. Polymers from a levopimaric acid-acrylonitrile Diels-Alder adduct: Synthesis and characterization. J. Polym. Sci. A 2005, 43, 6308-6322. [CrossRef]

217. Atta, A.; Al-Lohedan, H.; Al-Hussain, S.; Atta, A.M.; Al-Lohedan, H.A.; Al-Hussain, S.A. Functionalization of magnetite nanoparticles as oil spill collector. Int. J. Mol. Sci. 2015, 16, 6911-6931. [CrossRef]

218. Atta, A.M.; Akl, Z.F. Removal of thorium from water using modified magnetite nanoparticles capped with rosin amidoxime. Mater. Chem. Phys. 2015, 163, 253-261. [CrossRef]

219. Li, M.; Jiang, J.; Zhang, J.; Yang, X.; Zhang, Y.; Li, S.; Song, J.; Huang, K.; Xia, J. Preparation of a new liquid thermal stabilizer from rosin and fatty acid and study of the properties of the stabilized PVC. Polym. Degrad. Stab. 2014, 109, 129-136. [CrossRef]

220. Chen, P.; Zeng, X.; Li, H.; Liu, X.; Liu, D.; Li, X. Preparation and characterization of polyacrylate/polymerized rosin composite emulsions by seeded semicontinuous emulsion polymerization. J. Appl. Polym. Sci. 2012, 124, 4694-4701. [CrossRef]

221. Chen, P.; Zeng, X.; Li, H.; Liu, X.; Liu, D.; Li, X. Effect of polymerized rosin on polymer microstructure and adhesive properties in tackified acrylate emulsions. Polym. Plast. Technol. Eng. 2012, 51, 122-127. [CrossRef]

222. Foreiter, M.B.; Gunaratne, H.Q.N.; Nockemann, P.; Seddon, K.R.; Stevenson, P.J.; Wassell, D.F. Chiral thiouronium salts: Synthesis, characterisation and application in NMR enantio-discrimination of chiral oxoanions. New J. Chem. 2013, 37, 515-533. [CrossRef]

223. Guo, X.-T.; Sha, F.; Wu, X.-Y. Highly enantioselective Michael addition of $\alpha, \alpha$-disubstituted aldehydes to nitroolefins. Res. Chem. Intermed. 2016, 42, 6373-6380. [CrossRef]

224. Reddy, B.V.S.; Swain, M.; Reddy, S.M.; Yadav, J.S. Enantioselective Michael addition of 2-hydroxy-1,4-naphthoquinone and 1,3-dicarbonyls to $\beta$-nitroalkenes catalyzed by a novel bifunctional rosin-indane amine thiourea catalyst. RSC Adv. 2013, 3, 8756-8765. [CrossRef]

225. Zhang, G.; Zhang, Y.; Jiang, X.; Yan, W.; Wang, R. Highly enantioslective synthesis of multisubstituted polyfunctional dihydropyrrole via an organocatalytic tandem michael/cyclization sequence. Org. Lett. 2011, 13, 3806-3809. [CrossRef]

226. Reddy, B.V.S.; Swain, M.; Reddy, S.M.; Yadav, J.S.; Sridhar, B. Asymmetric Michael/hemiketalization of 5-hydroxy-2-methyl-4H-pyran-4-one to $\beta, \gamma$-unsaturated $\alpha$-ketoesters catalyzed by a bifunctional rosin-indane amine thiourea catalyst. RSC Adv. 2014, 4, 42299-42307. [CrossRef]

227. Jiang, X.; Zhang, Y.; Wu, L.; Zhang, G.; Liu, X.; Zhang, H.; Fu, D.; Wang, R. Doubly stereocontrolled asymmetric aza-Henry reaction with in situ generation of $\mathrm{N}$-Boc-imines catalyzed by novel rosin-derived amine thiourea catalysts. Adv. Synth. Catal. 2009, 351, 2096-2100. [CrossRef]

228. Zhang, H.-R.; Xue, J.-J.; Chen, R.; Tang, Y.; Li, Y. A bifunctional rosin-derived thiourea catalyzed asymmetric tandem reaction and its new mechanism. Chin. Chem. Lett. 2014, 25, 710-714. [CrossRef]

229. Jiang, X.; Wang, Y.; Zhang, G.; Fu, D.; Zhang, F.; Kai, M.; Wang, R. Enantioselective synthesis of cyclic thioureas via mannich reaction and concise synthesis of highly optically active methylthioimidazolines: discovery of a more potent antipyretic agent. Adv. Synth. Catal. 2011, 353, 1787-1796. [CrossRef]

230. Jiang, X.; Fu, D.; Zhang, G.; Cao, Y.; Liu, L.; Song, J.; Wang, R. Highly diastereo- and enantioselective Mannich reaction of lactones with N-Boc-aldimines catalyzed by bifunctional rosin-derived amine thiourea catalysts. Chem. Commun. 2010, 46, 4294-4296. [CrossRef] 
231. Jiang, X.; Wu, L.; Xing, Y.; Wang, L.; Wang, S.; Chen, Z.; Wang, R. Highly enantioselective Friedel-Crafts alkylation reaction catalyzed by rosin-derived tertiary amine-thiourea: synthesis of modified chromanes with anticancer potency. Chem. Commun. 2011, 48, 446-448. [CrossRef]

232. Jiang, X.; Zhang, Y.; Liu, X.; Zhang, G.; Lai, L.; Wu, L.; Zhang, J.; Wang, R. Enantio- and diastereoselective asymmetric addition of 1,3-dicarbonyl compounds to nitroalkenes in a doubly stereocontrolled manner catalyzed by bifunctional rosin-derived amine thiourea catalysts. J. Org. Chem. 2009, 74, 5562-5567. [CrossRef]

233. Zhao, X.; Kang, T.; Shen, J.; Sha, F.; Wu, X. Enantioselective allylic amination of morita-baylis-hillman acetates catalyzed by chiral thiourea-phosphine. Chin. J. Chem. 2015, 33, 1333-1337. [CrossRef]

234. Zhu, H.; Jiang, X.; Li, X.; Hou, C.; Jiang, Y.; Hou, K.; Wang, R.; Li, Y. Highly enantioselective synthesis of $\mathrm{N}$-protected $\beta$-amino malonates catalyzed by magnetically separable heterogeneous rosin-derived amino thiourea catalysts: a stereocontrolled approach to $\beta$-amino acids. ChemCatChem 2013, 5, 2187-2190. [CrossRef]

235. Lin, N.; Long, X.W.; Chen, Q.; Zhu, W.R.; Wang, B.C.; Chen, K.B.; Jiang, C.W.; Weng, J.; Lu, G. Highly efficient construction of chiral dispirocyclic oxindole/thiobutyrolactam/chromanone complexes through Michael/cyclization cascade reactions with a rosin-based squaramide catalyst. Tetrahedron 2018, 74, 3734-3741. [CrossRef]

236. Cao, Y.; Jiang, X.; Liu, L.; Shen, F.; Zhang, F.; Wang, R. Enantioselective Michael/cyclization reaction sequence: Scaffold-inspired synthesis of spirooxindoles with multiple stereocenters. Angew. Chem. Int. Ed. 2011, 50, 9124-9127. [CrossRef]

237. Pan, D.; Wu, A.; Li, P.; Xu, H.; Lei, F.; Shen, L. Palladium-loaded renewable polymer as a green heterogeneous catalyst for cross-coupling reactions under microwave irradiation. J. Chem. Res. 2014, 38, 715-718. [CrossRef]

238. Morkhade, D.M.; Nande, V.S.; Barabde, U.V.; Patil, A.T.; Joshi, S.B. PEGylated rosin derivatives: Novel microencapsulating materials for sustained drug delivery. AAPS PharmSciTech 2007, 8, E134. [CrossRef]

239. Morkhade, D.M.; Nande, V.S.; Barabde, U.V.; Joshi, S.B. Study of biodegradation and biocompatibility of PEGylated rosin derivatives. J. Bioact. Compat. Polym. 2017, 32, 628-640. [CrossRef]

240. Morkhade, D.M.; Nande, V.S.; Barabde, U.V.; Patil, A.T.; Joshi, S.B. Design and evaluation of dental films of PEGylated rosin derivatives containing sparfloxacin for periodontitis. Drug. Dev. Ind. Pharm. 2018, 44, 914-922. [CrossRef]

241. El-Mahdy, G.A.; Atta, A.M.; Al-Lohedan, H.A. Water soluble nonionic rosin surfactants as corrosion inhibitor of carbon steel in $1 \mathrm{M} \mathrm{HCl}$. Int. J. Electrochem. Sci. 2013, 8, 5052-5066.

242. Chen, Y.; Wilbon, P.A.; Chen, Y.P.; Zhou, J.; Nagarkatti, M.; Wang, C.; Chu, F.; Decho, A.W.; Tang, C. Amphipathic antibacterial agents using cationic methacrylic polymers with natural rosin as pendant group. RSC Adv. 2012, 2, 10275-10282. [CrossRef]

243. Kaith, B.S.; Jindal, R.; Sharma, R. Synthesis of a gum rosin alcohol-poly(acrylamide) based adsorbent and its application in removal of malachite green dye from waste water. RSC Adv. 2015, 5, 43092-43104. [CrossRef]

244. Jindal, R.; Kaith, B.S.; Sharma, R. Central composite design model to study swelling of GrA-cl-poly(AAm) hydrogel and kinetic investigation of colloidal suspension. J. Polym. Environ. 2018, 26, 999-1011. [CrossRef]

245. Ganewatta, M.S.; Ding, W.; Rahman, M.A.; Yuan, L.; Wang, Z.; Hamidi, N.; Robertson, M.L.; Tang, C. Biobased plastics and elastomers from renewable rosin via "living" ring-opening metathesis polymerization. Macromolecules 2016, 49, 7155-7164. [CrossRef]

246. Rahman, M.A.; Lokupitiya, H.N.; Ganewatta, M.S.; Yuan, L.; Stefik, M.; Tang, C. Designing block copolymer architectures toward tough bioplastics from natural rosin. Macromolecules 2017, 50, 2069-2077. [CrossRef]

247. Choi, S.J.; Yim, T.; Cho, W.; Mun, J.; Jo, Y.N.; Kim, K.J.; Jeong, G.; Kim, T.-H.; Kim, Y.-J. Rosin-embedded poly(acrylic acid) binder for silicon/graphite negative electrode. ACS Sustain. Chem. Eng. 2016, 4, 6362-6370. [CrossRef]

248. Carbonell-Blasco, P.; Antoniac, I.V.; Martín-Martínez, J.M. New polyurethane sealants containing rosin for non-invasive disc regeneration surgery. Key Eng. Mater. 2014, 583, 67-79. [CrossRef]

249. Carbonell-Blasco, P.; Martín-Martínez, J.M.; Antoniac, I.V. Synthesis and characterization of polyurethane sealants containing rosin intended for sealing defect in annulus for disc regeneration. Int. J. Adhes. Adhes. 2013, 42, 11-20. [CrossRef]

250. Atta, A.M.; Elsaeed, A.M. Use of rosin-based nonionic surfactants as petroleum crude oil sludge dispersants. J. Appl. Polym. Sci. 2011, 122, 183-192. [CrossRef] 
251. Atta, A.M.; Ramadan, A.M.; Shaffei, K.A.; Nassar, A.M.; Ahmed, N.S.; Fekry, M. Synthesis and properties of nonionic surfactants from rosin-imides maleic anhydride adduct. J. Disper. Sci. Technol. 2009, 30, 1100-1110. [CrossRef]

252. Kaith, B.S.; Jindal, R.; Sharma, R. Study of ionic charge dependent salt resistant swelling behavior and removal of colloidal particles using reduced gum rosin-poly(acrylamide)-based green flocculant. Iran. Polym. J. 2016, 25, 349-362. [CrossRef]

253. Jindal, R.; Sharma, R.; Maiti, M.; Kaur, A.; Sharma, P.; Mishra, V.; Jana, A.K. Synthesis and characterization of novel reduced gum rosin-acrylamide copolymer-based nanogel and their investigation for antibacterial activity. Polym. Bull. 2017, 74, 2995-3014. [CrossRef]

254. Li, Q.; Huang, X.; Liu, H.; Shang, S.; Song, Z.; Song, J. Properties Enhancement of Room Temperature Vulcanized Silicone Rubber by Rosin Modified Aminopropyltriethoxysilane as a Cross-linking Agent. ACS Sustain. Chem. Eng. 2017, 5, 10002-10010. [CrossRef]

255. Li, Q.; Huang, X.; Liu, H.; Shang, S.; Song, Z.; Song, J. Preparation and properties of room temperature vulcanized silicone rubber based on rosin-grafted polydimethylsiloxane. RSC Adv. 2018, 8, 14684-14693. [CrossRef]

256. Xu, T.; Liu, H.; Song, J.; Shang, S.-B.; Song, Z.-Q.; Chen, X.-J.; Yang, C. Synthesis and characterization of imide modified poly(dimethylsiloxane) with maleopimaric acid as raw material. Chin. Chem. Lett. 2015, 26, 572-574. [CrossRef]

257. Lin, R.; Li, H.; Long, H.; Su, J.; Huang, W. Structure and characteristics of lipase-catalyzed rosin acid starch. Food Hydrocoll. 2015, 43, 352-359. [CrossRef]

258. Lin, R.; Li, H.; Long, H.; Su, J.; Huang, W. Synthesis of rosin acid starch catalyzed by lipase. BioMed Res. Int. 2014, 2014, 647068. [CrossRef]

259. De Castro, D.O.; Bras, J.; Gandini, A.; Belgacem, N. Surface grafting of cellulose nanocrystals with natural antimicrobial rosin mixture using a green process. Carbohydr. Polym. 2016, 137, 1-8. [CrossRef]

260. Niu, X.; Liu, Y.; Song, Y.; Han, J.; Pan, H. Rosin modified cellulose nanofiber as a reinforcing and co-antimicrobial agents in polylactic acid /chitosan composite film for food packaging. Carbohydr. Polym. 2018, 183, 102-109. [CrossRef]

261. George, M.; Mussone, P.G.; Bressler, D.C. Utilization of tall oil to enhance natural fibers for composite applications and production of a bioplastic. J. Appl. Polym. Sci. 2016, 133, 44327. [CrossRef]

262. Sacripante, G.G.; Zhou, K.; Farooque, M. Sustainable polyester resins derived from rosins. Macromolecules 2015, 48, 6876-6881. [CrossRef]

263. Yuan, L.; Hamidi, N.; Smith, S.; Clemons, F.; Hamidi, A.; Tang, C. Molecular characterization of biodegradable natural resin acid-substituted polycaprolactone. Eur. Polym. J. 2015, 62, 43-50. [CrossRef]

264. Wang, J.; Chen, Y.P.; Yao, K.; Wilbon, P.A.; Zhang, W.; Ren, L.; Zhou, J.; Nagarkatti, M.; Wang, C.; Chu, F.; et al. Robust antimicrobial compounds and polymers derived from natural resin acids. Chem. Commun. 2011, 48, 916-918. [CrossRef]

265. Ma, G.; Zhang, T.; Wu, J.; Hou, C.; Ling, L.; Wang, B. Preparation and properties of glycerin ester of tung oil modified rosin. J. Appl. Polym. Sci. 2013, 130, 1700-1706. [CrossRef]

266. Wu, J.; Zhang, T.; Ma, G.; Li, P.; Ling, L.; Wang, B. Synthesis of a tung oil-rosin adduct via the diels-alder reaction: Its reaction mechanism and properties in an ultraviolet-curable adhesive. J. Appl. Polym. Sci. 2013, 130, 4201-4208. [CrossRef]

267. Yu, C.; Chen, C.; Gong, Q.; Zhang, F.-A. Preparation of polymer microspheres with a rosin moiety from rosin ester, styrene and divinylbenzene. Polym. Int. 2012, 61, 1619-1626. [CrossRef]

268. Huang, J.F.; Shi, Q.S.; Feng, J.; Chen, M.J.; Li, W.R.; Li, L.Q. Facile pyrolysis preparation of rosin-derived biochar for supporting silver nanoparticles with antibacterial activity. Compos. Sci. Technol. 2017, 145, 89-95. [CrossRef]

269. Wang, L.; Shi, Y.; Wang, Y.; Zhang, H.; Zhou, H.; Wei, Y.; Tao, S.; Ma, T. Composite catalyst of rosin carbon/Fe3O4: Highly efficient counter electrode for dye-sensitized solar cells. Chem. Commun. 2014, 50, 1701-1703. [CrossRef]

270. Ruan, Z.; Wu, J.; Huang, J.F.; Lin, Z.T.; Li, Y.F.; Liu, Y.-L.; Cao, P.-Y.; Fang, Y.-P.; Xie, J.; Jiang, G.-B. Facile preparation of rosin-based biochar coated bentonite for supporting $\alpha$-Fe2O3 nanoparticles and its application for Cr(VI) adsorption. J. Mater. Chem. A 2015, 3, 4595-4603. [CrossRef] 
271. Zeng, C.; Lin, Q.; Fang, C.; Xu, D.; Ma, Z. Preparation and characterization of high surface area activated carbons from co-pyrolysis product of coal-tar pitch and rosin. J. Anal. Appl. Pyrol. 2013, 104, 372-377. [CrossRef]

272. Liu, H.; Du, S.; Chen, Y. Preparing mesoporous carbon and silica with rosin-silica composite gel. J. Nanosci. Nanotechnol. 2009, 9, 799-802. [CrossRef] 